UCRL-CR-125546

S/C- B330980

\title{
Environmental Impact Report Addendum for the Continued Operation of Lawrence Livermore National Laboratory
}

Prepared by:

Roy F. Weston, Inc.

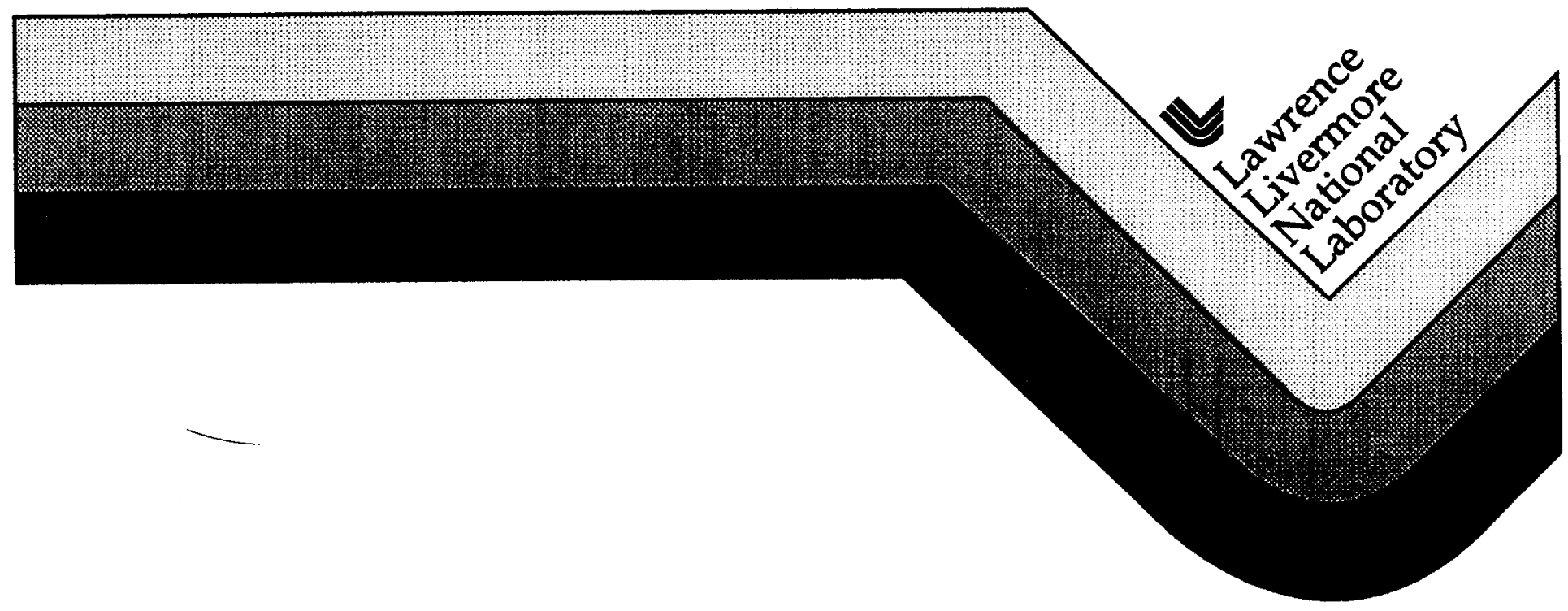




\section{DISCLAIMER}

This document was prepared as an account of work sponsored by an agency of the United States Government. Neither the United States Government nor the University of California nor any of their employees, makes any warranty, express or implied, or assumes any legal liability or responsibility for the accuracy, completeness, or usefulness of any information, apparatus, product, or process disclosed, or represents that its use would not infringe privately owned rights. Reference herein to any specific commercial product, process, or service by trade name, trademark, manufacturer, or otherwise, does not necessarily constitute or imply its endorsement, recommendation, or favoring by the United States Government or the University of California. The views and opinions of authors expressed herein do not necessarily state or reflect those of the United States Government or the University of California, and shall not be used for advertising or product endorsement purposes.

This report has been reproduced directly from the best available copy.

Available to DOE and DOE contractors from the Office of Scientific and Technical Information P.O. Box 62, Oak Ridge, TN 37831

Prices available from (615) 576-8401, FTS 626-8401

Available to the public from the National Technical Information Service

U.S. Department of Commerce 5285 Port Royal Rd., Springfield, VA 22161

Work performed under the auspices of the U.S. Department of Energy by Lawrence Livermore National Laboratory under Contract W-7405-ENG-48. 
University of California

ENVIRONMENTAL IMPACT REPORT ADDENDUM

for the Continued Operation of Lawrence Livermore National Laboratory

October 1996

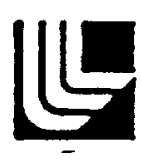




\section{CONTENTS}

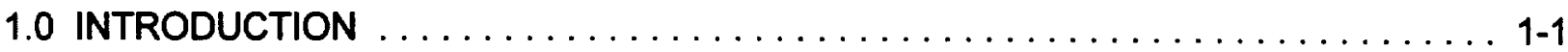

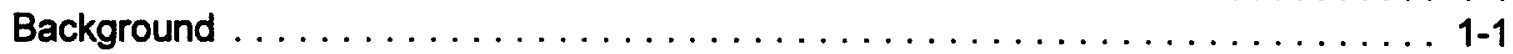

Authority for and Purpose of this Addendum $\ldots \ldots \ldots \ldots \ldots \ldots \ldots \ldots \ldots, 1-1$

Document Organization $\ldots \ldots \ldots \ldots \ldots \ldots \ldots \ldots \ldots \ldots \ldots \ldots \ldots \ldots \ldots \ldots, 1-2$

Review and Approval Process $\ldots \ldots \ldots \ldots \ldots \ldots \ldots \ldots \ldots \ldots \ldots \ldots \ldots \ldots \ldots, 1-3$

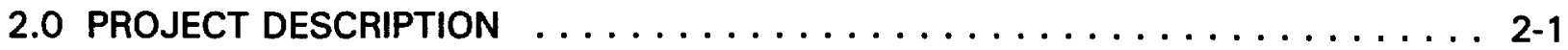

3.0 ENVIRONMENTAL SETTING AND IMPACT ANALYSIS $\ldots \ldots \ldots \ldots \ldots \ldots$ 3-1

3.1 Land Use and Applicable Plans $\ldots \ldots \ldots \ldots \ldots \ldots \ldots \ldots \ldots \ldots \ldots$

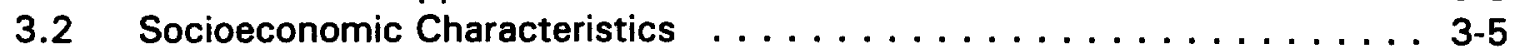

3.3 Community Services $\ldots \ldots \ldots \ldots \ldots \ldots \ldots \ldots \ldots \ldots \ldots \ldots$ 3-7

3.4 Prehistoric and Historic Cultural Resources . . . . . . . . . . 3-11

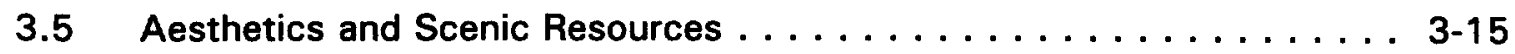

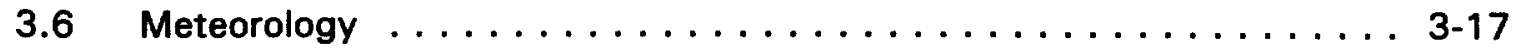

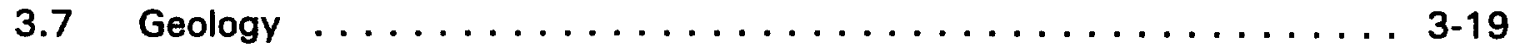

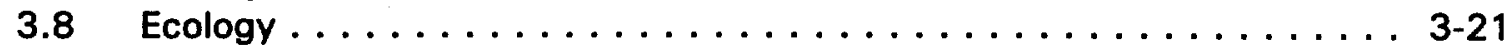

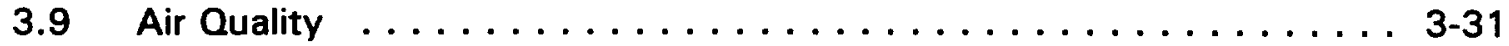

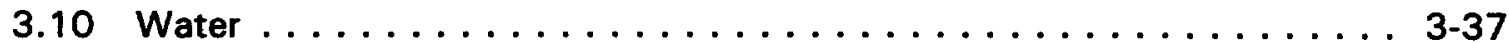

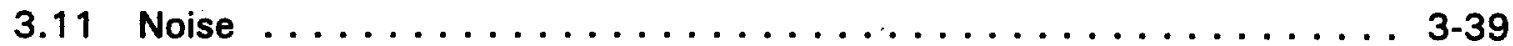

3.12 Traffic and Transportation .................. 3-43

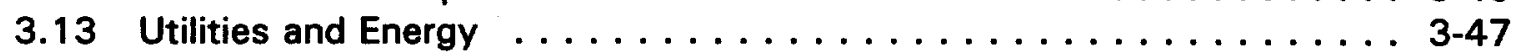

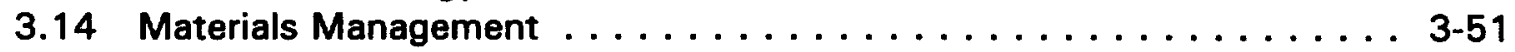

3.15 Waste Management ..................... 3-57

3.16 Occupational Protection $\ldots \ldots \ldots \ldots \ldots \ldots \ldots \ldots \ldots \ldots$ 3-63

3.17 Site Contamination and Remediation .............. 3-65

3.18 Environmental Compliance and Inadvertent Releases . . . . . . . 3-71

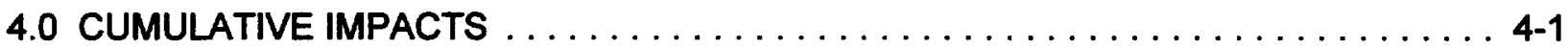

5.0 IRREVERSIBLE AND IRRETRIEVABLE COMMITMENT OF RESOURCES ...... 5-1

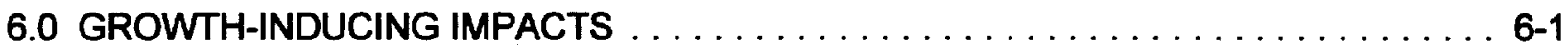

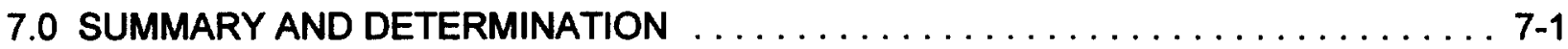

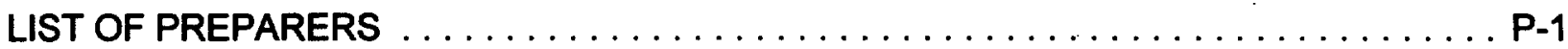

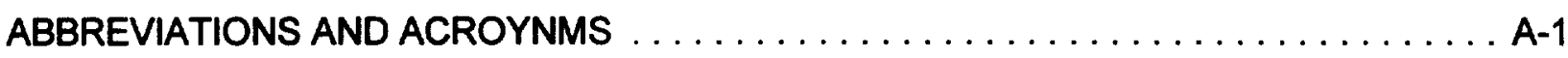

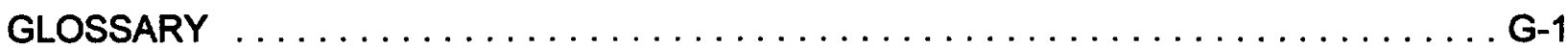

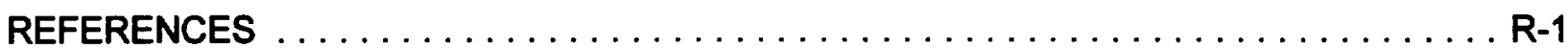




\section{TABLES}

Table Title

3.18-1 Summary of Unusual Environmental Occurrences at LLNL Livermore Site Since $1992 \ldots . . \ldots$. . . . . . . . . . . . . . 3-72

3.18-2 Summary of Unusual Environmental Occurrences at Site 300 Since 1992

\section{FIGURES}

Figure

2-1

$2-2$

3.8-1

$3.8-2$

3.17-1
Title

Page

Site Plan of the LLNL Livermore Site . . . . . . . . . . . . 2-2

Site Plan of the Experimental Test Site, Site $300 \ldots \ldots \ldots \ldots \ldots$ 2-3

Sensitive Natural Resources at the LLNL Livermore Site . . . . . . . . 3-23

Sensitive Natural Resources at Site $300 \ldots \ldots \ldots \ldots \ldots . \ldots . . \ldots \ldots$ 3-26

Delineation of Study Areas and Constituents

3-68 


\section{SECTION 1.0 \\ INTRODUCTION}

\section{BACKGROUND}

An environmental impact statement/environmental impact report (EIS/EIR) for the continued operation and management of Lawrence Livermore National Laboratory (LLNL) was prepared jointly by the U.S. Department of Energy (DOE) and the University of California (UC). The scope of the document included near-term (within 5-10 years) proposed projects. The UC Board of Regents, as state lead agency under the California Environmental Quality Act (CEQA), certified and adopted the EIR by issuing a Notice of Determination on November 20, 1992. The DOE, as the lead federal agency under the National Environmental Policy Act (NEPA), adopted a Record of Decision for the EIS on January 27, 1993 (58 Federal Register [FR] 6268).

The DOE proposed action was to continue operation of the facility, including near-term proposed projects. The specific project evaluated by UC was extension of the contract between UC and DOE for UC's continued operation and management of LLNL (both sites) from October 1, 1992, through September 30, 1997. The 1992 EIS/EIR (DOE, 1992a) analyzed impacts through the year 2002.

The 1992 EIS/EIR comprehensively evaluated the potential environmental impacts of operation and management of LLNL within the near-term future. Activities evaluated included programmatic enhancements and modifications of facilities and programs at the LLNL Livermore site and at LLNL's Experimental Test Site (Site 300) in support of research and development missions established for LLNL by Congress and the President. The evaluation also considered the impacts of infrastructure and building maintenance, minor modifications to buildings, general landscaping, road maintenance, and similar routine support activities.

\section{AUTHORITY FOR AND PURPOSE OF THIS ADDENDUM}

The contract between DOE and UC is scheduled for extension in October 1997. In evaluating the proposed project, UC considered whether to prepare an addendum to the 1992 EIS/EIR, a supplemental EIR, or a subsequent EIR. UC reviewed the standard for preparing these documents under CEQA and the State CEQA Guidelines. Briefly, the decision to prepare an addendum or a subsequent or supplemental EIR depends on whether: (1) there have been substantial changes in the project or in the circumstances surrounding the project that require major revisions to the EIR because of new or substantially more severe environmental impacts, or (2) new information shows that the project would have one or more significant effects not discussed in the EIR, that significant effects previously examined would be substantially more severe than shown in the EIR, that mitigation measures or alternatives previously found to be infeasible would in fact be feasible but the applicant declines to adopt them, or that mitigation measures or alternatives that are considerably different from those analyzed in the EIR would substantially reduce one or more significant impacts but the applicant declines to adopt them. If the proposed project involves such changes or new information, then UC must prepare a supplemental or subsequent EIR. If the proposed project does not involve such changes or new information, then UC may prepare an addendum. 
A significant effect to the environment is defined as a substantial, or potentially substantial, adverse change in any of the physical conditions within the area affected by a project. The State CEQA Guidelines allow a lead agency to prepare an addendum to update a previously certified EIR when none of the conditions described in the guidelines calling for preparation of a subsequent (or supplemental) EIR have occurred.

In light of this standard and on the basis of substantial evidence in the record, UC has determined that the proposed project does not involve substantial changes in the project or in the circumstances surrounding the project. Nor would the proposed project result in one or more new or substantially more severe significant environmental impacts. Instead, as explained below, the proposed project is consistent with the analysis already presented in the 1992 EIS/EIR. Accordingly, UC has determined that an addendum to the 1992 EIS/EIR is appropriate and has directed preparation of this addendum in compliance with the provisions of CEQA, the State CEQA Guidelines, and UC's CEQA guidelines.

\section{DOCUMENT ORGANIZATION}

This addendum is organized for ease of reference between this addendum and the $1992 \mathrm{EIS} / \mathrm{EIR}$. To avoid redundancy, the $1992 \mathrm{EIS/EIR}$ is referenced when possible in the discussion of issues, and is not reprinted. In general, issues in this addendum are discussed in the same order as in the 1992 EIS/EIR. The separate discussions of existing environment and environmental consequences, however, have been combined in this addendum as environmental setting and impact analysis.

To assist the reader in cross-referencing this addendum to the $1992 \mathrm{EIS} / \mathrm{EIR}$, each subsection of Section 3.0, "Environmental Setting and Impact Analysis," begins with a reference to the 1992 EIS/EIR. The first citation refers the reader to the appropriate description in Section 4.0, "Existing Environment," of the 1992 EIS/EIR. The second citation refers the reader to Section 5.0, "Environmental Consequences." The appendix citation (if any is warranted) cites the specific 1992 EIS/EIR appendix reference. The standards of significance citation identifies the pages where the standards of significance are discussed in the 1992 EIS/EIR. In technical areas where the standards of significance have changed since 1992, the new standards are included in this addendum.

Copies of the 1992 EIS/EIR for the Continued Operation of the Lawrence Livermore National Laboratory and copies of this addendum are available at:

LLNL Environmental Repository

Lawrence Livermore National Laboratory

7000 East Avenue

Livermore, CA 94550

(510) 424-4026

Livermore Public Library

1000 South Livermore Avenue

Livermore, CA 94550

(510) $373-5550$
Tracy Public Library

20 East Eaton Avenue

Tracy, CA 95376

(209) $831-4250$

UC Berkeley, Office of Planning and Design 300 Lakeside Drive, 12th Floor

Oakland, CA 94612

(510) $987-9596$ 
Copies of the draft Stockpile Stewardship and Management Programmatic Environmental Impact Statement (PEIS) (DOE, 1996a) and Decontamination and Waste Treatment Facility Environmental Assessment (DOE, 1996e) are available at:

U.S. Department of Energy

Public Reading Room, Room $180 \mathrm{~N}$

1301 Clay Street

Oakland, CA 94612

(510) 637-1762

\section{REVIEW AND APPROVAL PROCESS}

This addendum will be reviewed by the UC Board of Regents in considering its decision on whether to extend the contract to continue operating and managing LLNL (both sites) for DOE. Although CEQA does not require that the addendum be circulated to the public, the UC Board of Regents has made the draft addendum available for viewing by the public by providing copies to the libraries listed above. The UC Board of Regents will consider this addendum to the 1992 EIS/EIR before making a decision on the proposed project. 


\section{SECTION 2.0 \\ PROJECT DESCRIPTION}

The proposed project is an extension of the DOE/UC contract for continued operation and management of LLNL during the contract period (1997-2002). An EIS/EIR for the continued operation and management of LLNL (both sites) was prepared jointly by DOE and UC in 1992 (DOE, 1992a). The UC/DOE operating contract extension includes general provisions governing the role and responsibilities of UC and DOE but does not identify or implement specific development plans or research activities.

The 1992 EIS/EIR provided a comprehensive evaluation of the potential environmental impacts of the continued operation and management of LLNL through the year 2002. Activities evaluated included programmatic enhancements and modifications of facilities and programs at the LLNL Livermore site (Figure 2-1) and at LLNL's Experimental Test Site (Site 300) (Figure 2-2) in support of research and development missions established for LLNL by Congress and the President. The evaluation also considered the impacts of infrastructure and building maintenance problems, minor modifications to buildings, general landscaping, road maintenance, and similar routine support activities.

Many of the projected facilities and programs are currently undergoing or have undergone separate environmental review. Specific programs and facilities that are undergoing additional environmental review concurrently with the review of this addendum include the National Ignition Facility (NIF), the Contained Firing Facility (CFF), and the Decontamination and Waste Treatment Facility (DWTF). These additional environmental review documents include the Stockpile Stewardship and Management Programmatic EIS (PEIS) (DOE, 1996a) and the Decontamination and Waste Treatment Facility Environmental Assessment (DOE, 1996d), which are available from DOE's public information office at 1301 Clay Street, Oakland, California.

Projections for future programs and facilities for the period 1996-2002 remain within the parameters of the analysis presented in the 1992 EIS/EIR, and are summarized below:

- Facility changes resulting in space allocation at the LLNL Livermore site include the decommissioning and/or demolition of Chemistry Building 222 and the addition of the NIF, Genomics and Structural Research Facility, and the west wing addition to Building 543.

- Facility changes resulting in changes to space allocation at Site 300 include the decommissioning and/or demolition of the Advanced Test Accelerator Complex, the Fire Station and Medical Facility upgrade, and the addition of the Contained Firing Facility at the Building 801 Complex.

- Besides ongoing infrastructure, maintenance and minor upgrade activities at both sites, other proposed facilities and enhanced programs include the proposed Accelerated Cleanup Initiative and the Expedited Technology Demonstration project, the Decontamination and Waste Treatment Facility, and the privatization of the United States Enrichment Corporation (USEC).

Programs may be accelerated, delayed, or canceled with new planning and programs reassessed each year. 


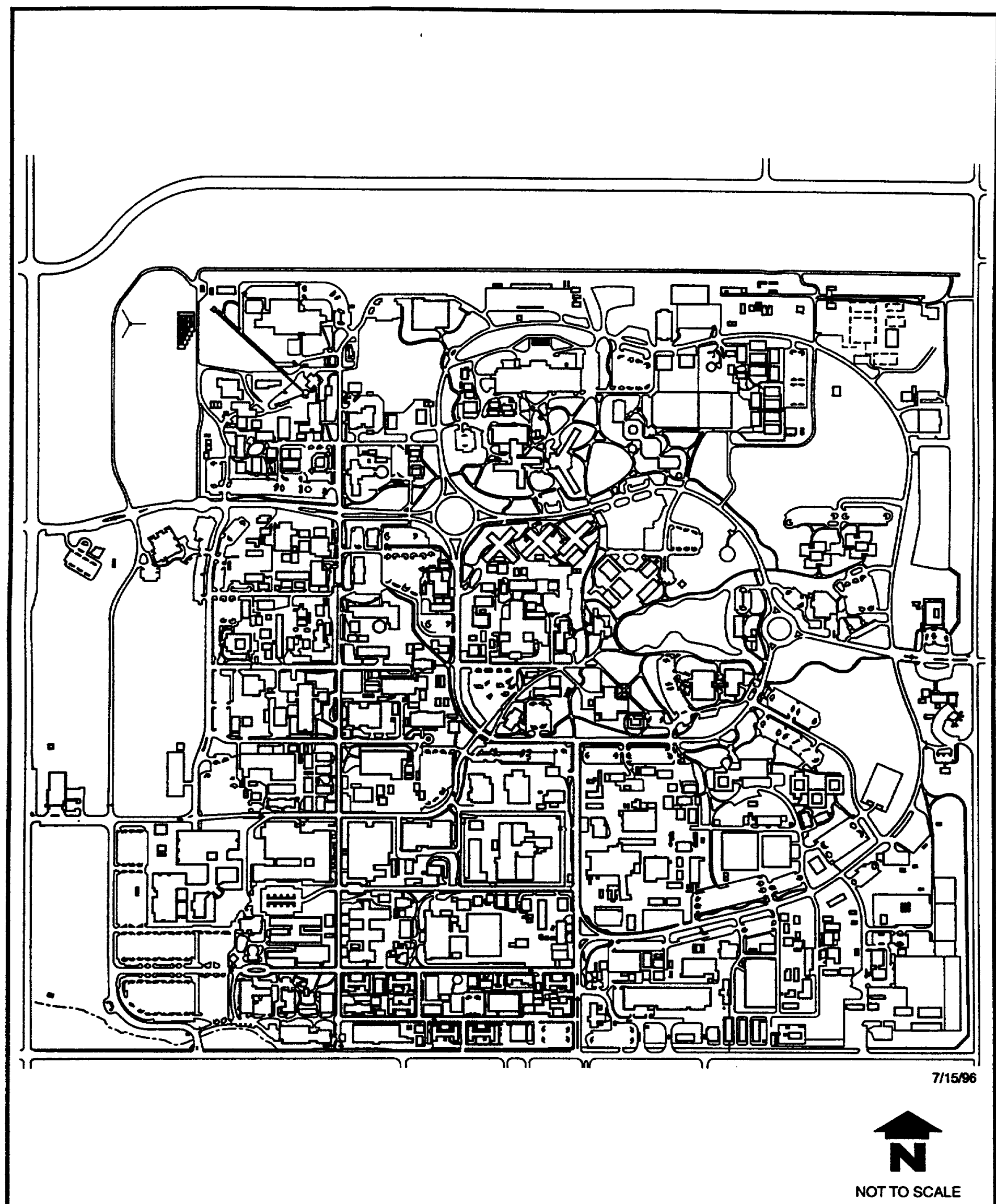

Figure 2-1. Site Plan of the LLNL Livermore Site 


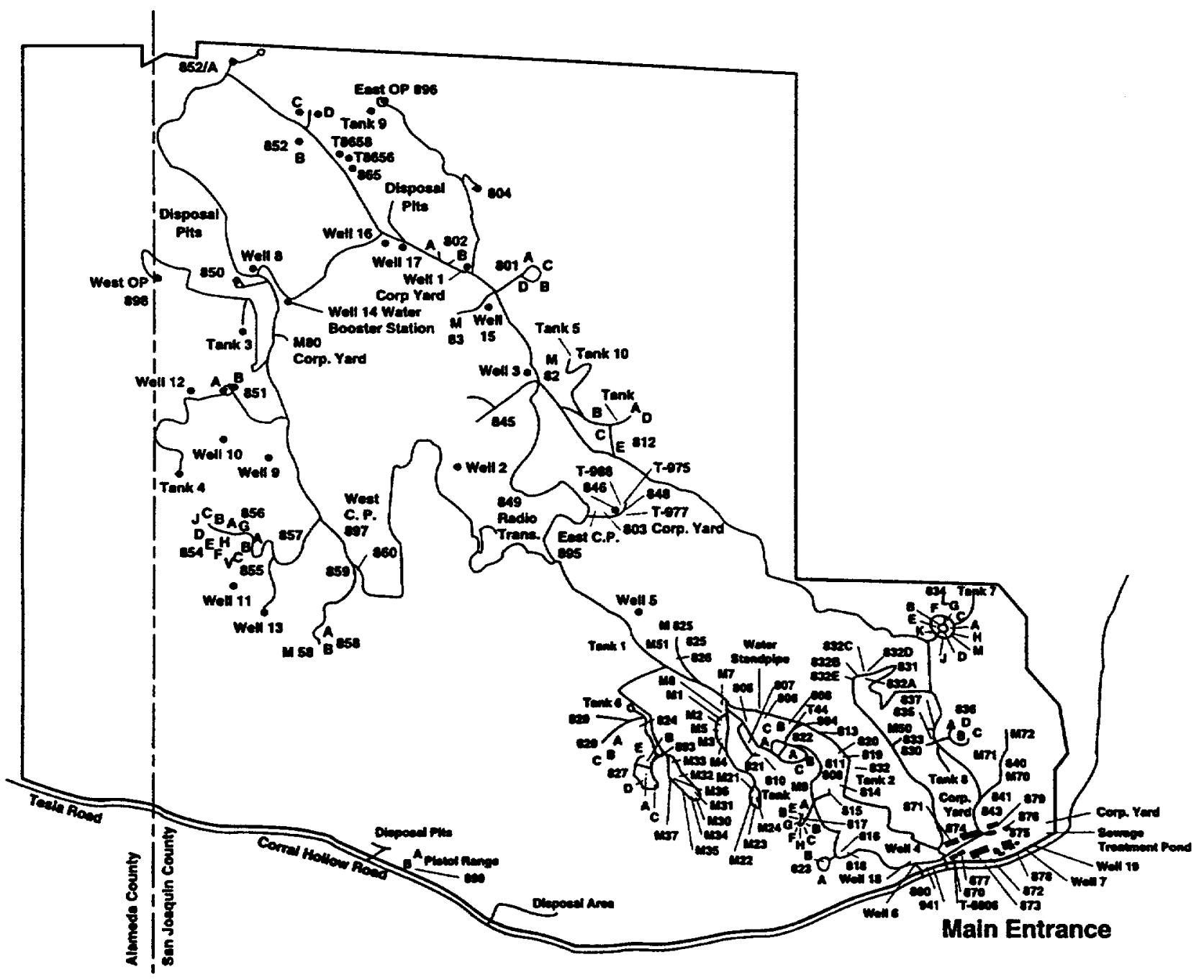

LEGEND

824 BUILDING

Corp. Yard CORPORATION YARD

East CP EAST CONTROL POST

East OP EAST OBSERVATION POST

M 825 MAGAZINE

T 8658 TRAILER

WESt CP WEST CONTROL POST

WESt OP WEST OBSERVATION POST

SCALE: METERS

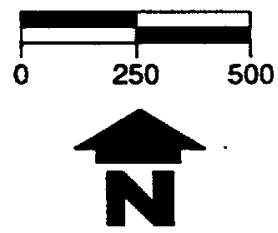

Figure 2-2. Site Plan of the Experimental Test Site, Site 300 


\section{SECTION 3.0 ENVIRONMENTAL SETTING AND IMPACT ANALYSIS}

Baseline data presented in the 1992 EIS/EIR were estimated from information available at that time. Information on existing conditions for each resource area discussed in this addendum reflects the most current actual data available for the 1992-1996 period at the time of addendum preparation.

In most cases, impacts and their level of significance were determined using the same significance criteria identified in the 1992 EIS/EIR. For two resource areas (i.e., "Prehistoric and Historic Cultural Resources" and "Air Quality"), significance criteria had changed since certification of the 1992 EIS/EIR, and potential impacts were analyzed on the basis of the new criteria. In both instances, the impacts are well within the parameters of the 1992 EIS/EIR and are therefore considered insignificant. 


\title{
3.1 LAND USE AND APPLICABLE PLANS
}

\author{
Subsection: 4.2, Subsection: 5.1 .1
}

Standards of Significance: Page 5-6

\section{SETTING}

\section{LLNL LIVERMORE SITE}

The following current documents were examined for consistency with the proposed project:

- $\quad$ East County Area Plan (County of Alameda, 1994)

- $\quad$ Alameda County Zoning Regulations (County of Alameda, 1992)

- $\quad$ Livermore Community General Plan (City of Livermore, 1996a)

- $\quad$ City of Livermore Zoning District Maps (City of Livermore, 1996c)

\section{Site 300}

The following current documents were examined for consistency with the proposed project:

- San Joaquin County General Plan 2010 (County of San Joaquin, 1992)

- County of Alameda General Plan (County of Alameda, 1994)

- $\quad$ County of San Joaquin Zoning Map (County of San Joaquin, 1996)

- $\quad$ East County Area Plan (County of Alameda, 1994)

- $\quad$ Alameda County Zoning Regulations (County of Alameda, 1992)

- City of Tracy General Plan (City of Tracy and The Planning Center, 1993)

\section{City of Tracy Planning Programs}

The 1993 updated City of Tracy General Plan revises land use designations within close proximity to Site 300 . The General Plan characterizes Site $\mathbf{3 0 0}$ land use as Federal Reserve/Open Space and divides the Tracy Planning Area into seven Community Areas, including the Tracy Hills Community Area. The Tracy Hills Community Area is a proposed planned community that would have an urban center near Interstate 580, just north of Corral Hollow Road. The urban center would be surrounded by primarily medium-density residential development. Industrial uses would be located near (primarily east of) Interstate 580 (City of Tracy and The Planning Center, 1993). According to the 1993 plan, very low-density residential element of the project would have bordered the northern and eastern portions of Site 300. Subsequently, the developer of the 3600-acre portion of the Tracy Hills Community Area nearest Site 300 has proposed incorporating a 1-mile permanent buffer zone/mitigation area between Site 300 and the housing development. The buffer zone/mitigation area proposed is for the protection of San Joaquin kit fox habitat and would be administered by the California Department of Fish and Game; thus, residences would be no closer than 1-1.5 miles east of Site 300's eastern boundary. The Tracy Hills Specific Plan and its associated EIR are presently being drafted by the City of Tracy and are expected to be released for public review in September 1996 (Conant, 1996). 


\section{IMPACTS}

\section{LLNL LIVERMORE SITE}

Impact: $\quad$ No impact on land use policies and standards.

Onsite land uses at the LLNL Livermore site have remained the same as those discussed in the 1992 EIS/EIR. New planning policies and standards are consistent with the previously adopted planning policies analyzed in the 1992 EIS/EIR and do not change the conclusions regarding impact significance identified in the 1992 EIS/EIR.

Although the types of land uses at the LLNL Livermore site would not change under the proposed project, some infill and modernization would occur onsite. In addition, short-term disturbance would occur within the northern security buffer area during construction of NIF to allow construction access to NIF site. However, this disturbance would be temporary. This impact is within the parameters of the $1992 \mathrm{EIS/EIR}$ and is considered to be insignificant.

\section{SITE 300}

Impact: No impact on land use policies and standards.

Onsite land uses at Site 300 have remained the same as those discussed in the 1992 EIS/EIR. New planning policies and standards are consistent with the previously adopted planning policies analyzed in the 1992 EIS/EIR and do not change the conclusions regarding impact significance identified in the 1992 EIS/EIR. The proposed project is consistent with surrounding land uses as described in the plans mentioned above.

\section{SUMMARY CONCLUSION}

The proposed project is consistent with the land use and applicable plans analysis presented in the 1992 EIS/EIR and does not involve substantial changes in the project or in the circumstances surrounding the project. In addition, this analysis does not indicate that the project would result in one or more new or substantially more severe significant environmental impacts. There are no mitigation measures or alternatives previously found to be infeasible that would in fact be feasible, nor are there mitigation measures or alternatives that are considerably different from those analyzed in the 1992 EIS/EIR that would substantially reduce one or more significant impacts that have not been adopted. 


\title{
3.2 SOCIOECONOMIC CHARACTERISTICS
}

\author{
Subsection: 4.3, Subsection: $\mathbf{5 . 1 . 2}$
}

Standards of Significance: Page 5-14

Discussions of the LLNL Livermore site and Site 300 have been combined in this subsection.

\section{SETTING}

\section{LLNL LIVERMORE SITE AND SITE 300}

Table 3.2-1 summarizes changes to socioeconomic conditions related to LLNL (both sites). As of July 26, 1996, LLNL's (both sites) total workforce, which includes UC and DOE employees and contractors, was 8965 employees (8718 at the LLNL Livermore site and 247 at Site 300) (LLNL, 1996e; Cronister, 1996). USEC employees and contractors were not included in the workforce count to allow comparison with the information provided in the 1992 EIS/EIR. In April 1996, LLNL (both sites) began implementation of a Voluntary Separation Incentive Program that is designed to reduce the current UC LLNL total workforce by approximately 500-600 employees. Estimated changes to the LLNL workforce, including the Voluntary Separation Incentive Program, indicate that a $6.5 \%$ reduction from current conditions is expected by 2005 .

Table 3.2-1. Summary of Changes in Economic Conditions at LLNL

\begin{tabular}{|c|c|c|c|c|}
\hline & 1992 EIS/EIR & $\begin{array}{c}\text { Current Conditions } \\
\text { (1996) }\end{array}$ & $\begin{array}{c}\text { Percentage } \\
\text { Change } \\
(1992-1996) \\
\end{array}$ & $\begin{array}{c}\text { Projected } \\
\text { Conditions (2005) }\end{array}$ \\
\hline \multirow{2}{*}{$\begin{array}{l}\text { Total work-force } \\
\text { (UC employees and } \\
\text { contractors) }\end{array}$} & $\begin{array}{c}11,200 \\
\text { (Livermore site) }\end{array}$ & $\begin{array}{c}8718 \\
\text { (Livermore site) }\end{array}$ & -22.2 & \multirow{2}{*}{$\begin{array}{c}\text { Approximately } \\
8382^{\mathbf{a}} \\
\text { (Livermore site } \\
\text { and Site } 300 \text { ) }\end{array}$} \\
\hline & 200 (Site 300 ) & 247 (Site 300) & +23.5 & \\
\hline $\begin{array}{l}\text { Monthly payroll } \\
\text { (LLNL [both sites] } \\
\text { employees) }\end{array}$ & $\$ 36.0$ million & $\$ 40.6$ million & +12.8 & $\begin{array}{l}\text { Approximately } \\
\$ 38.0 \text { million }^{\text {b.c }}\end{array}$ \\
\hline $\begin{array}{l}\text { Total economic } \\
\text { influence in region }\end{array}$ & $\$ 767.6$ million & $\$ 774.6$ million & +0.9 & $\begin{array}{l}\text { Approximately } \\
\$ 684.0 \text { million }^{\circ}\end{array}$ \\
\hline
\end{tabular}

a Workforce projections for 2005 are used because 2002 projections are not available. Projected population numbers include proposed Voluntary Separation Incentive Program reductions.

- Payroll projections assume changes that are comparable to workforce changes.

c The effects of inflation were not incorporated into these estimates.

Sources: LLNL, 1996e; Cronister, 1996; DOE, $1996 a$. 


\section{IMPACTS}

\section{LLNL LIVERMORE SITE AND SITE 300}

Impact: No impact on socioeconomic characteristics.

Socioeconomic impacts were identified in the 1992 EIS/EIR that were associated with projected growth through 2002. Changes to programs at LLNL (both sites) described in this addendum have resulted in a smaller combined workforce and are expected to remain stable through 2002. Previously identified impacts either will not occur due to downsizing or will be considerably less than identified in the 1992 EIS/EIR.

\section{SUMMARY CONCLUSION}

The proposed project is consistent with the socioeconomic characteristics analysis presented in the 1992 EIS/EIR and does not involve substantial changes in the project or in the circumstances surrounding the project. In addition, this analysis does not indicate that the project would result in one or more new or substantially more severe significant environmental impacts. There are no mitigation measures or alternatives previously found to be infeasible that would in fact be feasible, nor are there mitigation measures or alternatives that are considerably different from those analyzed in the 1992 EIS/EIR that would substantially reduce one or more significant impacts that have not been adopted. 


\title{
3.3 COMMUNITY SERVICES
}

\author{
Subsection: 4.4, Subsection: $\mathbf{5 . 1 . 3}$
}

Standards of Significance: Page 5-28

Discussions of the LLNL Livermore site and Site 300 have been combined in this subsection.

\section{SETTING}

\section{LLNL LIVERMORE SITE AND SITE 300}

\section{Fire Protection and Emergency Services}

Since certification of the 1992 EIS/EIR, some minor changes have occurred at the LLNL Livermore site and Site 300, including reorganization of the Fire Safety Division as the Emergency Management Division and changes to some of the equipment used for fire protection and emergency services. No substantial changes have occurred since 1992.

\section{Police and Security Services}

Minor changes have occurred in the police and security forces at LLNL (both sites) since certification of the 1992 EIS/EIR. The Protective Force Division currently employs approximately 180 personnel (compared with approximately 200 personnel in 1992), maintains the same equipment as described in 1992 (although the canine units are no longer in use), and maintains the emergency response agreements with other law enforcement agencies (Lawrence, 1996). No substantial changes have occurred since 1992.

\section{School Services}

Since 1992, new school facilities in the Livermore Valley have been constructed. The current enrollment has increased to 11,587 from the 1992 level of 10,058 (McNeely, 1996). This increase is not attributable to LLNL. The number of LLNL (both sites) workforce personnel living in the City of Livermore and the Livermore Valley Joint Unified School District has declined and the number of students in the school district associated with employees of LLNL has also dropped substantially, from 1688 in 1991 to 680 in 1996 (a 60\% decline). Students associated with LLNL employees are now $6 \%$ of the school district's enrollment, which is a decline from $17 \%$ in 1992.

\section{Nonhazardous and Nonradioactive Solid Waste Disposal}

Nonhazardous solid waste generated at the LLNL Livermore site continues to be transported to the Vasco Road Landfill for disposal. The 1992 EIS/EIR estimated solid waste generation to be approximately 24,000 cubic yards per year (approximately 9600 tons, assuming 800 pounds per cubic yard for compacted garbage). 
Construction of the new NIF, beginning in 1997, is expected to generate approximately 1200 cubic yards (900 cubic meters) of nonroutine, nonhazardous solid waste. As indicated in the 1992 EIS/EIR, adequate capacity exists to handle this waste. (DOE, 1996b).

In 1995, the total amount of solid waste disposed by LLNL (both sites) at the Vasco Road Landfill was 9355 tons. This was approximately $75 \%$ in weight of the overall solid waste stream generated at the LLNL Livermore site. The remaining $25 \%$ of the solid waste stream ( 3045 tons) was recycled and thus diverted from the landfill. Besides the recycling programs identified in the 1992 EIS/EIR, new programs have been instituted at both sites to recycle paper, cardboard, newspaper, magazines, wood materials, and items such as batteries and printer toner cartridges (LLNL, 1996j).

In 1992, approximately 200 cubic yards per month of landscaping wastes were sent to the landfill. The LLNL Livermore site is now composting for reuse all of its landscaping waste.

The 1992 EIS/EIR indicated that solid waste from Site 300 was disposed of at the Corral Hollow Landfill, which was scheduled for closure. The Corral Hollow Landfill has closed and solid waste is now sent to the Tracy Materials Recovery Facility, where recyclables are removed. The remaining waste is then ultimately transferred to the Foothills Landfill for disposal (LeStrange, 1996).

The 1992 EIS/EIR estimated that approximately 2200 cubic yards (approximately 880 tons, assuming $\mathbf{8 0 0}$ pounds per cubic yard for compacted garbage) of solid waste per year were generated at Site 300. In 1995, Site 300 disposed of 265 cubic yards ( 47.5 tons, uncompacted) of solid waste.

\section{IMPACTS}

\section{LLNL LIVERMORE SITE AND SITE 300}

Impact: No impact on fire protection and emergency services.

The projected changes in gross square footage at LLNL Livermore site and Site 300 as well as the combined workforce are well within the parameters projected in the 1992 EIS/EIR. These changes would not generate added demand for fire protection and emergency services.

Impact: No impact on police and protective services.

The projected changes in gross square footage at the LLNL Livermore site and Site 300 as well as the combined workforce are well within the parameters projected in the 1992 EIS/EIR. These changes would not require added demand for police and security services.

Impact: No impact on schools.

In 1992, the increased demand for school services attributable to an increased workforce at LLNL (both sites) was expected to result in a potentially significant and unavoidable impact. However, because current LLNL (both sites) workforce projections are much lower than forecast in the 1992 EIS/EIR and would remain about the same through the year 2002, no new impact would result. 
Impact: No impact on nonhazardous and nonradioactive solid waste disposal.

No new impacts would result because the proposed project would not result in the generation of large amounts of solid waste or require substantial expansion of existing solid waste facilities. The generation of solid waste would have no impact because the Tracy Material Recovery Facility has become available to receive the solid waste which previously went to the Corral Hollow Landfill. The new landfill is approximately 5 miles from the Coral Hollow Landfill.

\section{SUMMARY CONCLUSION}

The proposed project is consistent with the community services analysis presented in the 1992 EIS/EIR and does not involve substantial changes in the project or in the circumstances surrounding the project. In addition, this analysis does not indicate that the project would result in one or more new or substantially more severe significant environmental impacts. There are no mitigation measures or alternatives previously found to be infeasible that would in fact be feasible, nor are there mitigation measures or alternatives that are considerably different from those analyzed in the 1992 EIS/EIR that would substantially reduce one or more significant impacts that have not been adopted. 


\title{
3.4 PREHISTORIC AND HISTORIC CULTURAL RESOURCES
}

\author{
Subsection: 4.5, Subsection: 5.1.4, Appendix H
}

Standards of Significance: Page 5-39

SETTING

In 1992, the state legislature amended CEQA, establishing criteria for determining whether a resource is "historical" (Pub. Res. Code 21084.1) and creating the California Register of Historic Resources. A historic resource may be eligible for inclusion on the California Register if it is associated with events of significance with regard to California history or cultural heritage, or associated with lives of persons important to California's past. A resource may be eligible because it has distinctive historic characteristics, represents the work of an important individual, or possesses high artistic value. Lastly, a resource may be eligible because it can yield information important in prehistory or history. CEQA states that an impact is considered significant if a project would have an adverse effect that may change the significance of a resource (Pub. Res. Code 21084.1). Demolition, replacement, substantial alteration, and relocation of historic properties are actions that may change the significance of a historical resource.

In the 1992 EIS/EIR, treatment of cultural resources under CEQA was largely subsumed within measures to comply with Section 106 of the National Historic Preservation Act, following guidance from the Governor's Office of Planning and Research.

In 1994, consultation with the State Historic Preservation Officer and the Advisory Council on Historic Preservation was begun to develop a draft Programmatic Agreement to guide DOE Oakland Operations Office (DOE/OAK) and LLNL in the implementation of measures to comply with Section 106 and in the development of a cultural resource management plan for LLNL. After review of the first draft Programmatic Agreement by the State Historic Preservation Officer and the Advisory Council on Historic Preservation, their comments were incorporated into a proposed final draft Programmatic Agreement that has been resubmitted to DOE/OAK for final review and comment by the two agencies. DOE/OAK will then distribute copies to the public for review and comment, as required by Section 106 of the National Historic Preservation Act, before it is signed. The document will be distributed to local government agencies, historical societies, and those Native American groups and individuals designated by the State of California Native Heritage Commission as interested parties for the LLNL region.

\section{LLNL LIVERMORE SITE}

\section{Prehistoric Resources}

Since certification of the 1992 EIS/EIR, additional cultural survey efforts at the LLNL Livermore site have not identified any prehistoric archaeological resources. However, as indicated in the 1992 EIS/EIR, the probability for such finds near LLNL is low due to the lack of water, food, and shelter in prehistoric times. 


\section{Prehistoric Resources}

Pursuant to the efforts described above, additional surveys have been completed and are ongoing at Site 300 . No new prehistoric resources of significance have been identified.

\section{Historic-Period Resources}

Pursuant to the efforts described above, additional surveys have been completed and are ongoing. There are no new additional significant historic-period resources.

\section{STANDARDS OF SIGNIFICANCE}

As described under the "Setting" portion of this section, the California Register of Historic Resources was created in 1992 and provides state historic resource criteria that were not considered when the 1992 EIS/EIR was certified.

A project that may cause a substantial adverse change in the significance of a historic resource is a project that may have a significant effect on the environment. (Pub. Res. Code 21084.1.) An "important" archaeological resource is defined as one that:

- Is associated with an event or person of recognized significance in California or American history or recognized scientific importance in prehistory;

- Can provide information that is of demonstrable public interest and is useful in addressing scientifically consequential and reasonable research questions;

- Has special or particular quality such as oldest, best example, largest, or last surviving example of its kind;

- Is at least 100 years old and possesses substantial stratigraphic integrity; or

- Involves important research questions that historical research has shown can be answered only with archaeological methods.

For the purposes of this addendum, potential disturbances of "important" archaeological resources, or of historic resources that are listed on any national, state, or local historical registers, are considered to be significant adverse impacts.

For both prehistoric and historic resources, the impact assessment methodology is similar. The resources within the Area of Potential Effect, defined as part of the historic property identification phase requirements of Section 106 of the National Historic Preservation Act, were identified through literature search and/or field reconnaissance. (See Appendix $H$ of the 1992 EIS/EIR for a more detailed description of the Section 106 process.) Resources outside that area are determined not to be affected by the proposed action. Resources within the Area of Potential Effect will be evaluated to determine their eligibility for listing in the National Register of Historic 
Places (in consultation with the State Historic Preservation Officer) or other designation by state (such as a state historic landmark) or local government as an important resource.

If a resource is determined to be within the Area of Potential Effect and is potentially eligible for listing in the National Register of Historic Places or is otherwise designated an important resource, it will be evaluated for potential adverse effects. The evaluation of adverse effects in this EIS/ËIR does not constitute the formal Determination of Effect element of the Section 106 process. It does, however, provide an overview analysis of the potential for disturbance to or disruption of cultural resources under the proposed action. The Section 106 process will be completed before federal funding is approved for the individual projects included in the proposed action.

\section{IMPACTS}

Discussions of the LLNL Livermore site and Site $\mathbf{3 0 0}$ have been combined in this subsection.

\section{LLNL LIVERMORE SITE AND SITE 300}

Impact: Construction activities associated with the proposed project could result in destruction or disturbance to prehistoric and historic resources. This impact is considered less than significant since any significant finds will be protected pursuant to the 1992 EIS/EIR.

Implementing the measures identified in the 1992 EIS/EIR and enforcing appropriate policies and procedures would minimize adverse effects.

\section{SUMMARY CONCLUSION}

The proposed project is consistent with the prehistoric and historic cultural resources analysis presented in the 1992 EIS/EIR and does not involve substantial changes in the project or in the circumstances surrounding the project. In addition, this analysis does not indicate that the project would result in one or more new or substantially more severe significant environmental impacts. There are no mitigation measures or alternatives previously found to be infeasible that would in fact be feasible, nor are there mitigation measures or alternatives that are considerably different from those analyzed in the 1992 EIS/EIR that would substantially reduce one or more significant impacts that have not been adopted. 


\title{
3.5 AESTHETICS AND SCENIC RESOURCES
}

\author{
Subsection: 4.6, Subsection: $\mathbf{5 . 1 . 5}$
}

Standards of Significance: Page 5-51

Discussions of the LLNL Livermore site and Site $\mathbf{3 0 0}$ have been combined in this subsection.

\section{SETTING}

\section{LLNL LIVERMORE SITE AND SITE 300}

\section{Visual Character of the Project Vicinity}

The visual character of areas surrounding the LLNL Livermore site has changed slightly since certification of the 1992 EIS/EIR. An apartment complex has been constructed near the westsouthwest corner of the LLNL Livermore site. Another change is a veterinarian's office that was constructed east of the LLNL Livermore site along Greenville Road.

The visual character of areas surrounding Site 300 has not changed since the 1992 EIS/EIR was prepared.

\section{Views of the Sites from the Surrounding Areas}

Although the LLNL Livermore site and Site $\mathbf{3 0 0}$ have ongoing programs that require physical changes to some facilities and buildings, the visual character as viewed from surrounding areas has remained the same as described in the 1992 EIS/EIR.

\section{Scenic Resources Policies}

The scenic route element of the County of Alameda General Plan has remained unchanged since the 1992 EIS/EIR (McElligott, 1996).

The San Joaquin County General Plan was updated on July 29, 1992. The Resources Element incorporates and supersedes the 1978 Scenic Highways Element of the San Joaquin General Plan (Tiernan, 1996). Seven miles of Corral Hollow Road in San Joaquin County, the southern boundary of Site 300, has since become a county-designated scenic route (County of San Joaquin, 1992). Site 300 development has been minimal and therefore, there has been little impact associated with this new designation. 


\section{IMPACTS}

\section{LLNL LIVERMORE SITE AND SITE 300}

Impact: Recent and proposed construction is within the parameters of the impacts projected in the 1992 EIS/EIR. Impacts remain less than significant.

Construction projected at the LLNL Livermore site and Site 300 would not adversely affect views from surrounding scenic roadways and nearby residences. The physical changes would retain the existing visual character of LLNL's (both sites) research, business, and industrial-oriented development.

New local policies and standards are consistent with the previously adopted planning policies analyzed in the $1992 \mathrm{EIS} / \mathrm{EIR}$ and do not change the conclusion regarding impact significance.

\section{SUMMARY CONCLUSION}

The proposed project is consistent with the aesthetics and scenic resources analysis presented in the 1992 EIS/EIR and does not involve substantial changes in the project or in the circumstances surrounding the project. In addition, this analysis does not indicate that the project would result in one or more new or substantially more severe significant environmental impacts. There are no mitigation measures or alternatives previously found to be infeasible that would in fact be feasible, nor are there mitigation measures or alternatives that are considerably different from those analyzed in the 1992 EIS/EIR that would substantially reduce one or more significant impacts that have not been adopted. 


\subsection{METEOROLOGY}

\section{Subsection: 4.7}

\section{Standards of Significance: Not applicable}

Discussions of the LLNL Livermore site and Site 300 have been combined in this subsection.

\section{SETTING}

\section{LLNL LIVERMORE SITE AND SITE 300}

Long-term climatological changes at LLNL cannot be assessed on the basis of meteorological data for the four-year period since the 1992 EIS/EIR was published; however, analysis of that data revealed short-term changes.

Annual average temperatures during the most recent five-year period (1991-1995) have increased by $2.4^{\circ} \mathrm{F}\left(1.3^{\circ} \mathrm{C}\right)$ compared with the ten-year averaging period described in the $1992 \mathrm{EIS} / \mathrm{EIR}$ (National Oceanic and Atmospheric Administration, 1995). During the same period, annual average precipitation increased by 2.15 inches (National Oceanic and Atmospheric Administration, 1995). The increase in precipitation reflects a return to normal conditions from the previous drought period that ended during the early 1990s. Wind speed and direction were generally unchanged (LLNL, 1995b). Meteorological conditions are not expected to change substantially through 2002, except for typical short-term variations.

\section{IMPACTS}

\section{LLNL LIVERMORE SITE AND SITE 300}

Impact: No impact on meteorological conditions.

There are no new impacts associated with meteorological conditions. Effects-modeling efforts that require the input of assumed meteorological parameters and that may be needed within the next 5 years should be comparable to those that were assessed in the 1992 EIS/EIR. 


\section{SUMMARY CONCLUSION}

The proposed project is consistent with the meteorology analysis presented in the 1992 EIS/EIR and does not involve substantial changes in the project or in the circumstances surrounding the project. In addition, this analysis does not indicate that the project would result in one or more new or substantially more severe significant environmental impacts. There are no mitigation measures or alternatives previously found to be infeasible that would in fact be feasible, nor are there mitigation measures or alternatives that are considerably different from those analyzed in the 1992 EIS/EIR that would substantially reduce one or more significant impacts that have not been adopted. 


\title{
3.7 GEOLOGY
}

\author{
Subsection: 4.8, Subsection: 5.1.6, Appendix I
}

Standards of Significance: Page 5-58

SETTING

LLNL LIVERMORE SITE AND SITE 300

Discussions of the LLNL Livermore site and Site $\mathbf{3 0 0}$ have been combined in this subsection.

No substantial changes in geologic conditions, including geologic hazards, have occurred since certification of the 1992 EIS/EIR.

\section{IMPACTS}

\section{LLNL LIVERMORE SITE}

Impact: Ground-shaking events may expose facilities to structural damage and people to hazards. This impact is within the parameters of the impact described in the 1992 EIS/EIR.

Under the proposed project (as described in Section 2.0, "Project Description"), the amount of building square footage and the number of people employed at the LLNL Livermore site, would remain within the projections analyzed in the 1992 EIS/EIR. Thus, the total potential exposure of structures and people to the effects of ground-shaking events would be within the impact parameters described in the 1992 EIS/EIR. Mitigation measures adopted for the 1992 EIS/EIR remain appropriate and adequate to mitigate for the impacts of construction projects that were considered in the 1992 EIS/EIR analysis.

Impact. Expansive or shrink-swell soils and soils with low permeability could affect proposed structures. This impact is within the parameters of the impact described in the 1992 EIS/EIR.

Under the proposed project, the amount of building construction would be within the projections in the 1992 EIS/EIR. Thus, potential impacts resulting from specific soil conditions would remain within the parameters of the impact described in the 1992 EIS/EIR. 
SITE 300

Impact: Ground-shaking events may expose facilities to structural damage and people to hazards. This impact is considered less than significant.

Under the proposed project, the number of people employed at Site 300 and the total square footage of new facilities would remain within the parameters of the 1992 EIS/EIR. Mitigation measures adopted for the 1992 EIS/EIR would be appropriate and adequate to mitigate projected changes at Site 300 .

\section{SUMMARY CONCLUSION}

The proposed project is consistent with the geology analysis presented in the 1992 EIS/EIR and does not involve substantial changes in the project or in the circumstances surrounding the project. In addition, this analysis does not indicate that the project would result in one or more new or substantially more severe significant environmental impacts. There are no mitigation measures or alternatives previously found to be infeasible that would in fact be feasible, nor are there mitigation measures or alternatives that are considerably different from those analyzed in the 1992 EIS/EIR that would substantially reduce one or more significant impacts that have not been adopted. 


\subsection{ECOLOGY}

Subsection: 4.9, Subsection: 5.1.7, Appendix F, Appendix G

Standards of Significance: Page 5-65

\section{SETTING}

\section{LLNL LIVERMORE SITE}

\section{Vegetation}

Minor changes in vegetation or vegetation management associated with construction activities have occurred at the LLNL Livermore site since certification of the 1992 EIS/EIR. In general, these changes have increased the developed and landscaped area and decreased the area of non-native grassland.

\section{Fish and Wildlife}

There have been minor changes in the status of general wildlife at the LLNL Livermore site since certification of the 1992 EIS/EIR. Changes include occurrences of new common wildlife species (i.e., grey fox and black-necked stilt) or changes in the density or location of common species.

\section{Special-Status Species}

Special-status plant and wildlife species are legally protected or of special concem under the state and federal Endangered Species Acts and the California Fish and Game Code. All special-status species potentially affected were considered during preparation of the 1992 EIS/EIR.

New information on special-status species known to occur onsite, beyond that described in the 1992 EIS/EIR, typically falls in one of three categories:

- The legal status of the species has changed since publication of the EIS/EIR;

- A species reported in the EIS/EIR has been observed in a new location; or

- A new special-status species not previously reported in the EIS/EIR has been observed.

\section{Plants}

Recent requests for information from the California Department of Fish and Game and the U.S. Fish and Wildlife Service have yielded updated lists of special-status plant species potentially occurring on the LLNL Livermore site (Aasen, 1995; Medlin, 1995). Twelve special-status plant species have been identified and may occur in the vicinity of the LLNL Livermore site that were not addressed in the 1992 EIS/EIR. The 1992 EIS/EIR predicted that the probability of special-status plant species occurring on the project site was low, based on previous vegetation surveys 
performed more than ten years before. Because no surveys for special-status plant species have been performed at the LLNL Livermore site, it cannot be determined whether or not special-status plant species actually occur on the project site or would be affected by the proposed project or its changes. The extensive development of the site over the past 45 years, whether due to past construction or landscaping activities, reduces the probability of special status plants occurring at the LLNL Livermore site.

\section{Wildlife}

Since certification of the 1992 EIS/EIR, two special-status wildlife species not recorded during previous surveys have been observed at the LLNL Livermore site. A pair of white-tailed kites (a species formerly known as the black-shouldered kite) was observed in 1994 and 1995 nesting just south of East Gate Drive (Figure 3.8-1). The white-tailed kite is considered a species of special concern by the California Department of Fish and Game. The pair of kites nested successfully and fledged young (Woollett, 1996). No kites have been observed nesting in the same location in 1996, although individual white-tailed kites have been observed numerous times in the vicinity by various Laboratory personnel.

Since publication of the 1992 EIS/EIR, several pairs of burrowing owls have been observed in the grassland habitat of the security buffer area on the north and west sides of the Laboratory (Figure 3.8-1). Burrowing owls are considered a species of special concern by the California Department of Fish and Game.

Burrowing owls may migrate short or long distances from winter to summer (Zeiner et al., 1990) and therefore may use numerous burrows over time. This is the case in the security buffer area on the north side of the Laboratory where nests were observed in 1995 and 1996. As a result, all grassland areas in the security buffer area have been identified and are managed as potential burrowing owl nesting habitat in a manner consistent with the 1992 EIS/EIR.

\section{Wetlands}

Wetlands on the LLNL Livermore site along Arroyo Los Positas have expanded in area since certification of the 1992 EIS/EIR, and additional unmapped wetland areas have formed in drainages at other locations on the site (Kato, 1996; Matthews, 1996; Rued, 1996). The 1992 EIS/EIR stated that wetlands might develop around the edge of the retention basin; this has not occurred. Routine maintenance would occur in site drainage ditches to keep the ditches clear for their designated use.

\section{SITE 300}

\section{Vegetation}

Minor, undocumented changes in vegetation or vegetation management have occurred at Site 300 since certification of the 1992 EIS/EIR. These changes include year-to-year variation in the acreage of controlled burns and the location of fire roads (Woollett, 1996).

\section{Fish and Wildife}

Minor changes in general wildlife conditions may have occurred at Site 300 since certification of the 1992 EIS/EIR. These changes could include occurrences of new common wildlife species or changes in the density or location of common species. 


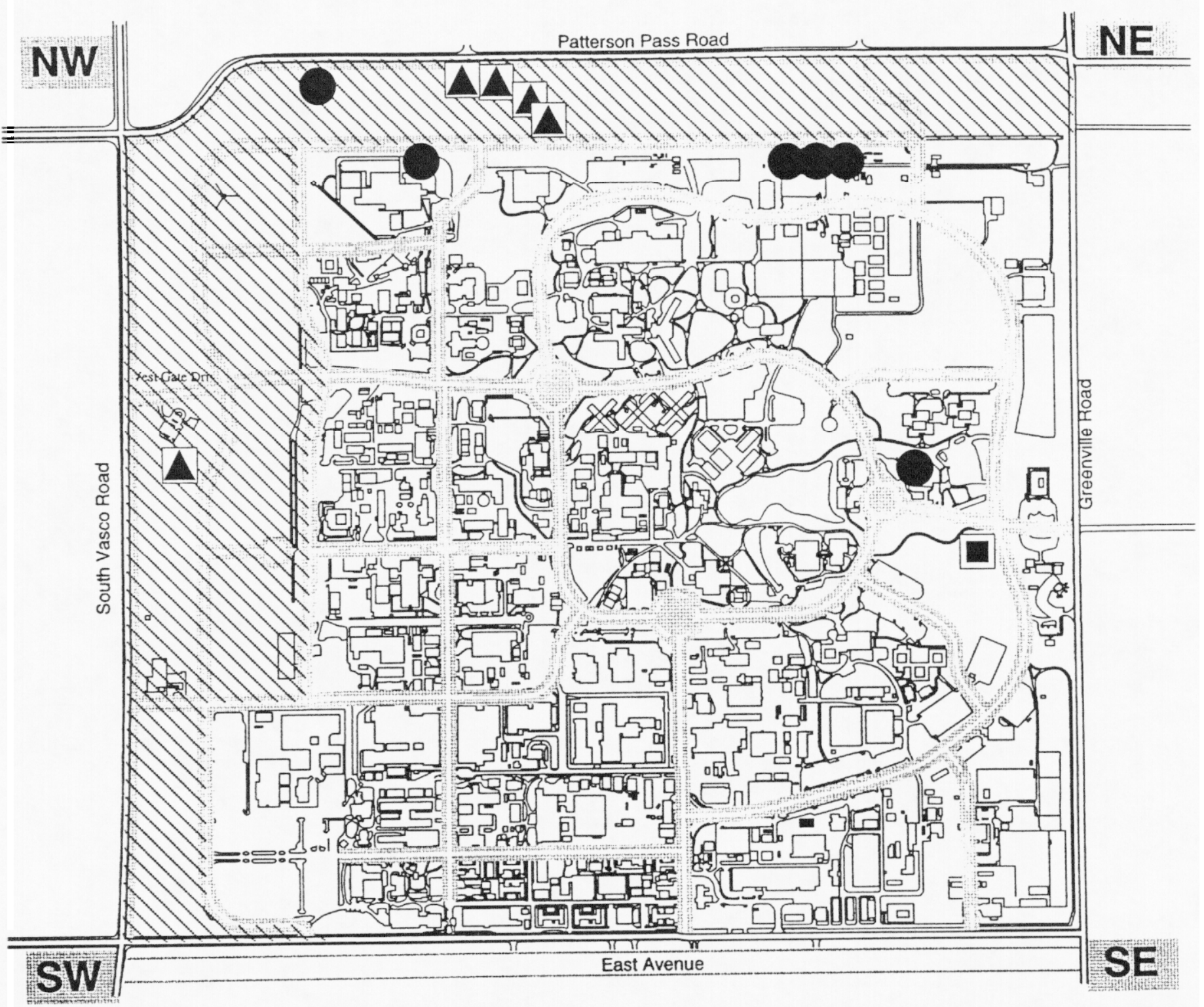

LEGEND

A BURROWING OWL DEN

WETLAND HABITAT

WHITE-TAILED KITE NEST $(1994,1995)$

SECURITY BUFFER ZONE

RESOURCE OCCURRENCES NOT IDENTIFIED IN 1992 EIS/EIR

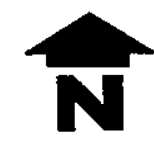

NOT TO SCALE

(As of 7/96 V-016-96)

Figure 3.8-1. Sensitive Natural Resources at the LLNL Livermore Site 
New observations of special-status species are described below.

\section{Special-Status Plant and Wildlife Species}

\section{Plants}

Surveys for special-status plant species conducted for the 1992 EIS/EIR focused on habitats with the best potential to support the large-flowered fiddleneck and on the sites of specific proposed projects. Two populations of large-flowered fiddleneck occur on Site 300 . Since the 1992 EIS/EIR was certified, the Laboratory has undertaken a unique project aimed at protecting the largeflowered fiddleneck. Characterization of the species habitat (including soils and slope preference) and the establishment of experimental populations are the major factors of this effort (Carlsen, 1996).

The large-flowered fiddleneck appears to prefer north-facing lands at a $40-50 \%$ slope. Soil preference is sandy clay loam. The Laboratory has successfully undertaken an artificial seeding program at two locations. One of these areas has shown progress in sustaining its growth and will be managed together with the two natural populations. Because of the slope and soils preference for the large-flowered fiddleneck, it is highly unlikely to be found in areas suitable for Site 300 development (Carlsen, 1996). No large-flowered fiddlenecks have been observed at Site 300 beyond those discussed above.

Since preparation of the 1992 EIS/EIR, the California Department of Fish and Game has deleted eight special status plant species and added 12 new species to the list of special status plants. Of the 12 plants on the California Native Plant Society's list, no suitable habitat exists at Site 300 for four species. A recent habitat survey of Site 300 indicates that there is unsuitable habitat for an additional 11 species in the areas of the proposed projects.

Potential habitat for the remaining one species does exist. The species of concern is:

\section{- Blephanizonia plumosa ssp. plumosa (Big Tarplant)}

Based on the potential for suitable habitat, a formal field survey was conducted at and around several proposed facilities at Site 300 . Several other sites where work may be proposed were also examined. The survey results indicated that five populations of Blepharazonia plumosa ssp. plumosa have been located at Site 300 . The populations ranged from a single plant at the south end of the Chemical Magazines area (M30-M37) to between 500 and 1500 plants near the proposed drainage area.

Because of the presence of this new special status species, LLNL has developed a workplan to protect this species including; characterizing the habitat of the population, delineation of the major populations, and flagging and counting these areas.

\section{Wildife}

The listing status for several previously identified special-status species at Site 300 has changed since the 1992 EIS/EIR was certified. The California red-legged frog was identified at Site 300 in the 1992 EIS/EIR. At that time, the species was considered a Category 2 candidate for federal listing as threatened or endangered. However, on May 23, 1996, the U.S. Fish and Wildlife Service listed the red-legged frog as threatened under the federal Endangered Species Act (federal ESA) 
(61 FR 25813, May 23, 1996). The listing of the red-legged frog as threatened triggers specific protections required under the federal ESA.

Since certification of the 1992 EIS/EIR, red-legged frogs have been observed at six new locations at Site 300 (Woollett, 1996). Locations of the new observations and observations noted in the 1992 EIS/EIR are shown in Figure 3.8-2. None of the proposed projects have the potential to impact the red-legged frog habitat.

The listing status for several species of fairy shrimp addressed in the 1992 EIS/EIR has changed since certification of the document. The 1992 EIS/EIR identified four species of fairy shrimp with potential to occur at Site 300 (vernal pool fairy shrimp, California linderiella, Conservancy fairy shrimp, and longhorn fairy shrimp). All four were described as Category 1 candidates for federal listing as threatened or endangered (DOE, 1992b). A final rule on the listing of these species was published in September 1994 (59 FR 48136, September 19, 1994). The Conservancy fairy shrimp and longhorn fairy shrimp were listed as endangered and the vernal pool fairy shrimp was listed as threatened.

No fairy shrimp were observed during wildlife surveys associated with the 1992 EIS/EIR. During subsequent surveys conducted in 1994, 1995, and 1996, California linderiella was found in water bodies at Site 300 (Woollett, 1996). The presence or absence of listed fairy shrimp species cannot be confirmed until more extensive surveys are completed. At this time, areas of standing water, such as the vernal pool and ponds in the northwest corner of Site 300, should be considered potential fairy shrimp habitat.

The 1992 EIS/EIR states that the California tiger salamander was reported at Site 300 (Orloff, 1986) but was not observed during surveys conducted in 1991.

Currently, this species is listed as a candidate species with a level 8 priority for federal listing based on the U.S. Department of the Interior's Proposed Rule for Endangered and Threatened Species, Plant and Animal Taxa (61 FR 7596, February 28, 1996). Listing priorities range from one to twelve, with one being the highest priority. A listing priority of eight indicates a species is exposed to low to moderate threat; however, the immediacy of the threat is considered imminent (48 FR 43098, September 21, 1983). Recent surveys at Site 300 conducted in 1994, 1995, and 1996 have identified five water bodies used as breeding sites by California tiger salamander (Woollett, 1996) (Figure 3.8-2).

The status of the Alameda whipsnake under the federal ESA has also changed since certification of the 1992 EIS/EIR. At that time, the Alameda whipsnake was identified as threatened under the California Endangered Species Act (CESA) and a Category 2 candidate for federal listing under the federal ESA. The Alameda whipsnake is still considered threatened under CESA; however, the species is now proposed for endangered status under the federal ESA. The Alameda whipsnake was observed at Site 300 in 1986 (Orloff, 1986). However, none have been observed at the site since that time.

The Swainson's hawk, listed as threatened under CESA, was not observed during surveys referenced in the 1992 EIS/EIR. However, a single individual was observed at Site 300 during winter 1994. Swainson's hawks were not observed nesting at the site and likely were utilizing the area for foraging or were passing through during seasonal migrations (Woollett, 1996). 


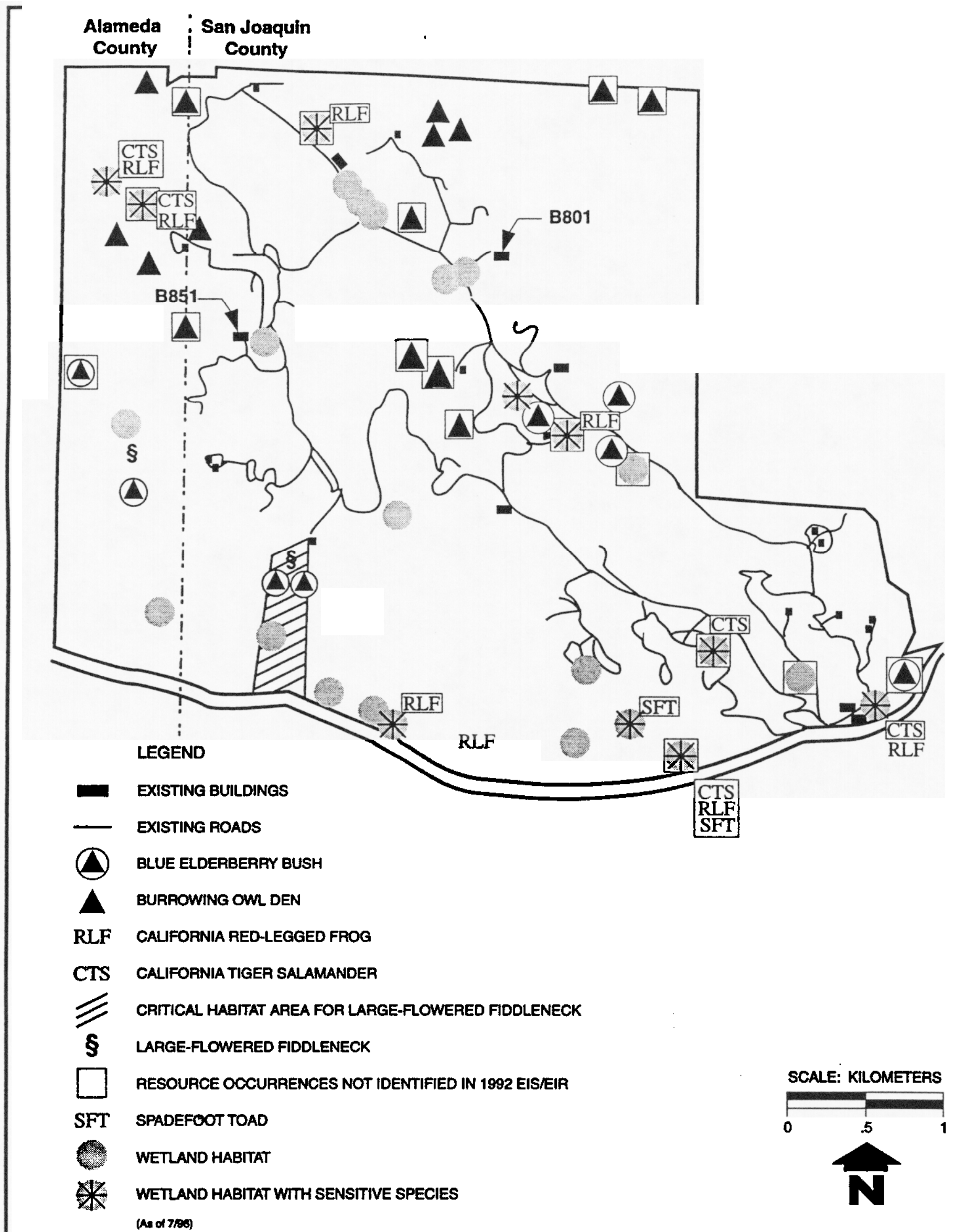

Figure 3.8-2. Sensitive Natural Resources at Site 300 
The spade-foot toad, considered a species of special concern by the California Department of Fish and Game, was not observed during surveys referenced in the $1992 \mathrm{EIS/EIR.} \mathrm{However,} \mathrm{this}$ species was found in two water bodies at Site 300 during recent surveys conducted in 1994, 1995, and 1996 (Figure 3.8-2) (Woollett, 1996).

Additional special-status species information also includes a 1996 observation of a pair of golden eagles nesting on a power pole at Site 300 and prairie falcons foraging at Site 300 (Woollett, 1996). The golden eagle and prairie falcon are both California species of special concern. Prairie falcons are not known to nest at Site 300; however, nests have been reported offsite near the facility.

Wetlands

Cooling tower water has been redirected to percolation pits, eliminating surface flow. Site 300 now maintains wetlands identified as "artificial" in the 1992 EIS/EIR with potable water, while exploring options to replace artificially maintained wetlands with a naturally fed wetland such as vernal pool habitat (Woollett, 1996). A few wetland areas not identified in the 1992 EIS/EIR have been identified on Site 300 , however, no wetland areas are currently proposed to be disturbed.

\section{IMPACTS}

\section{LLNL LIVERMORE SITE}

Impact: Clearing land for construction projects at the LLNL Livermore site could result in loss of vegetation. This impact is considered less than significant.

Impacts on vegetation are assessed by considering the type and extent of the vegetation community affected. Impacts could be considered significant if a rare or sensitive plant community, such as those found in riparian habitats, was removed. However, vegetation affected by construction projects at the LLNL Livermore site consists primarily of landscaping, ruderal vegetation, and non-native grassland. These vegetation types are not considered rare or sensitive; therefore, vegetation impacts as described above would be considered less than significant.

Impact: Common fish and wildlife species could be affected by proposed increased development associated with the projects. This impact is within the parameters of the impacts projected in the 1992 EIS/EIR.

The proposed project would have no new significant impacts on common fish and wildlife species. Increased development would affect habitat used by common wildlife species. However, the increase is small, and the expected losses are within the parameters identified in the 1992 EIS/EIR.

Impact: Construction activities could disturb burrowing owls at the LLNL Livermore site. This impact is considered within the parameters of the 1992 EIS/EIR.

Development in grasslands in the security buffer area and temporary disturbances associated with development, such as creation of staging areas or temporary access roads, could disturb or destroy nest burrows of the burrowing owl. Mitigation Measures 7.6.2T, 7.6.2U, 7.6.2V, and 7.6.2W from the $1992 \mathrm{EIS/EIR,} \mathrm{which} \mathrm{address} \mathrm{impacts} \mathrm{on} \mathrm{burrowing} \mathrm{owls} \mathrm{at} \mathrm{Site} \mathrm{300,} \mathrm{have} \mathrm{been}$ 
implemented on a project-by-project basis at the LLNL Livermore site since burrowing owls were first observed. No additional new mitigation measures are warranted.

Impact: $\quad$ Routine activities at the LLNL Livermore site may adversely affect wetlands in Arroyo Las Positas. This impact is considered less than significant.

The proposed construction projects would not adversely affect any wetland habitat on the LLNL Livermore site. However, routine maintenance would occur in the site drainage ditches to maintain the ditches for their designated use. These activities would be undertake after appropriate communication with the California Department of Fish and Game, to insure that impacts to any wetlands are less than significant.

\section{SITE 300}

Impact: Construction activities at Site 300 could result in loss of potential California tiger salamander upland habitat. This impact is considered less than significant.

Development of permanent facilities in grassland areas where tiger salamanders may estivate underground through summer may result in loss of potential habitat. However, the proposed project would remove an insignificant amount of available potential upland habitat at Site 300 . No breeding sites would be affected, and no potential migration routes between potential upland habitat and breeding ponds would be blocked.

Impact: No impact on wetland habitat.

The proposed project would not affect any wetland habitat at Site 300 . Because no wetlands would be affected, aquatic habitat components for wetlands-associated wildife species (California redlegged frog, California tiger salamander, fairy shrimp, and spade-foot-toad) also would not be affected.

Impact: No impact on special status plant species.

The proposed project would not affect any special status plant species at Site 300. A habitat survey for special status plants indicates that one plant species (Blepharazonia plumosa) has the potential to occur in the proposed project area. The Laboratory would survey the proposed project areas for the presence of special status species in the flowering season and would take appropriate measures to protect any special status plants that are identified. Activities that could potentially impact this special status species would be undertaken after appropriate communication with the California Department of Fish and Game to insure that impacts are less than significant. 


\section{SUMMARY CONCLUSION}

The proposed project is consistent with the ecology analysis presented in the 1992 EIS/EIR and does not involve substantial changes in the project or in the circumstances surrounding the project. In addition, this analysis does not indicate that the project would result in one or more new or substantially more severe significant environmental impacts. There are no mitigation measures or alternatives previously found to be infeasible that would in fact be feasible, nor are there mitigation measures or alternatives that are considerably different from those analyzed in the 1992 EISIEIR that would substantially reduce one or more significant impacts that have not been adopted. 


\subsection{Air Quality}

Subsection: 4.10, Subsection 5.1.8

Standards of Significance: Page 5-91

SETTING

The LLNL Livermore site and the extreme western section (west of the Alameda County line) of Site $\mathbf{3 0 0}$ are located in the Bay Area Air Quality Management District (BAAQMD). Most of Site 300 (east of the San Joaquin County line) is located in the San Joaquin Valley Unified Air Pollution Control District (SJVUAPCD).

\section{LLNL LIVERMORE SITE}

\section{Criteria Pollutants}

\section{Air Quality Monitoring Data}

Pollutant concentrations for ozone, carbon monoxide $(\mathrm{CO})$, nitrogen oxides $\left(\mathrm{NO}_{\mathrm{x}}\right)$, fine particulate matter less than 10 microns in diameter $\left(P M_{10}\right)$, and lead have been monitored continually at the downtown Livermore monitoring station. Taking into consideration expected year-to-year fluctuations, no substantial increases in pollutant concentrations have occurred.

\section{Toxic Air Contaminants}

\section{Air Quality Monitoring Data}

BAAQMD operates a network of air toxics monitoring stations throughout the San Francisco Bay Area Air Basin, including one monitoring station in Livermore. There have not been substantial changes in monitored air toxic contaminant levels since certification of the 1992 EIS/EIR.

\section{Emissions and Permitted Sources}

The 1992 EIS/EIR contained estimates of the LLNL Livermore site's carcinogenic, chronic, and acute worst-case health risks. These health risks were based on annual emission estimates of toxic air contaminants that were input into an air quality model, along with relevant data on meteorological conditions and receptors, to generate estimates of ambient 1-hour and annual pollutant concentrations. The results of the 1992 health risk assessment indicated that the health risks associated with the LLNL Livermore site did not pose significant carcinogenic, acute, or chronic risks.

The most recent annual report of toxic air contaminant emissions produced by the BAAQMD shows that the estimated 1994 toxic air emissions for the LLNL Livermore site are, with one exception, either below the emission estimates used to prepare the 1992 risk assessment or.below the BAAQMD's risk screening thresholds. Only formaldehyde, with 1994 emissions of 50 pounds per 
year, exceeds the 1992 baseline emissions of 35 pounds per year. Emissions of other pollutants in 1994 were substantially less than those used in the 1992 risk assessment. Formaldehyde emissions from the LLNL Livermore site are currently less than 5 pounds per year.

\section{Hazardous Air Pollutants}

Beryllium. LLNL's beryllium concentrations continue to be less than $1 \%$ of the BAAQMD's ambient monthly maximum standard. These data are consistent with monitored beryllium concentrations shown in the 1992 EIS/EIR. Beryllium emission levels are similar to those levels projected in the 1992 EIS/EIR.

Radionuclides. As with the monitored 1990 radionuclide levels reported in the 1992 EIS/EIR, the 1994 levels of the same radionuclides were a small percentage of the applicable significance threshold. The administrative limit for tritium onsite has been reduced as planned in the 1992 EIS/EIR, and all operations involving substantial quantities of tritium have been secondarily contained as of 1992. In 1990, a total of 1281 curies of tritium (700 curies in the form of water vapor and 581 curies of tritium gas) were monitored and released (DOE, 1992a). These levels of release have decreased to 76 curies of water vapor and 61 curies of tritium gas in 1994 (LLNL, 1995a). This is a decrease by a factor of 9 , compared with a decrease by a factor of 2-5 projected in the 1992 EIS/EIR. The concentration of tritium in air, both at the site boundary and in the Livermore Valley, has decreased by about the same relative amount, and the concentration of tritium in wines produced in the Livermore Valley has decreased by a factor of about 3 (LLNL, 1995a).

In 1990, the dose to the hypothetical maximally exposed individual of the general public was calculated to be 0.25 millirem effective dose equivalent (DOE, 1992a). This maximally exposed individual was assumed to reside offsite at the location of highest concentration of radionuclides and to consume radioactively contaminated foodstuffs and water. In 1994, the same hypothetical maximally exposed individual was calculated to receive 0.065 millirem effective dose equivalent (LLNL, 1995a), a reduction by a factor of 4 . These doses are far below any regulatory threshold and are insignificant when compared to the annual dose of $\mathbf{3 0 0}$ millirems received from background radiation.

SITE 300

\section{Criteria Pollutants}

\section{Air Quality Monitoring Data}

The description of air quality monitoring for the Site $\mathbf{3 0 0}$ area has not changed substantially from that published in the 1992 EIS/EIR.

\section{Toxic Air Contaminants}

\section{Air Quality Monitoring Data and Regulatory Conditions}

The closest toxic air contaminant monitoring station to Site 300 is located in Livermore (see previous discussion of the LLNL Livermore site). 


\section{Regulatory Conditions}

No substantial changes have been made since 1992.

Hazardous Air Pollutants

\section{Air Quality Monitoring Data}

Beryllium. No substantial changes in monitored beryllium levels have occurred at Site 300 compared with those reported in the 1992 EIS/EIR

Radionuclides. No substantial changes in monitored radionuclide levels have occurred at Site 300 compared with those reported in the 1992 EIS/EIR.

\section{Emissions}

Beryllium. No substantial increases in beryllium emissions have occurred at Site 300 compared with those reported in the 1992 EIS/EIR.

Radionuclides. No substantial increases in radionuclide emissions have occurred at Site 300 compared with those reported in the 1992 EIS/EIR.

\section{STANDARDS OF SIGNIFICANCE}

Since certification of the 1992 EIS/EIR, both air districts have developed guidelines identifying thresholds of significance for assessing the air quality impacts of proposed projects undergoing environmental review under CEQA. Additionally, in 1995, the BAAQMD received a new designation of attainment with respect to the federal ozone ambient air quality standard. The area is still designated as nonattainment for the state ambient air quality standard for ozone. No changes in Livermore-area attainment status for other pollutants regulated by the BAAQMD or SJVUAPCD have occurred since 1992.

The levels of significance used in the 1992 EIS/EIR were guided by the attainment status. However, this addendum uses significance thresholds developed by both districts. Therefore, the redesignation of attainment status does not affect the methodology used in the evaluation of significant impacts.

\section{IMPACTS}

\section{LLNL LIVERMORE SITE}

Impact: Operation of the LLNL Livermore site could increase emissions of criteria pollutants. This impact is considered less than significant. 
The level of criteria pollutants is a less-than-significant impact because the project-related increase in emissions is less than estimated in the 1992 EIS/EIR and is less than the BAAQMD significance thresholds.

Impact: Operation of buildings with boilers at the LLNL Livermore site could increase $\mathrm{NO}_{\mathrm{x}}$ emission levels. This impact is considered less than significant.

The following proposed structures and projects may require new boilers at the LLNL Livermore site, which could increase $\mathrm{NO}_{\mathrm{x}}$ emissions: the Accelerated Cleanup Initiative, the Energy Programs Office Building (replacement of trailers 4302, 4377, 4378, 4383, 4386, 4387, and 4388), and the Genomics and Structural Biology Research Facility.

Implementation of the Accelerated Cleanup Initiative would require the installation of two skid- or trailer-mounted boilers to generate steam, which, with oxygen, would be injected into the soil to heat both soil and contaminated water and produce rapid oxidation of the trichloroethylene contaminant. Specific equipment to be used in the Accelerated Cleanup Initiative has not yet been identified. For the purposes of this addendum, the boilers are estimated to use approximately 50 million British thermal units (BTUs) per hour of energy to produce approximately 22,680 kilograms (kg) $(50,000$ pounds) of steam per hour. This may generate a maximum of $4536 \mathrm{~kg}$ (5 tons) per year of $\mathrm{NO}_{\mathrm{x}}$. These values are preliminary estimates that may change as aspects of the Accelerated Cleanup Initiative are more clearly defined. The Accelerated Cleanup Initiative is considered to be the single largest potential new source of $\mathrm{NO}_{\mathrm{x}}$ at the LLNL Livermore site.

The results of modeling efforts showed that $\mathrm{NO}_{x}$ ground level concentrations would not exceed the BAAQMD's threshold level of significance of 19 micrograms per cubic meter (Gallegos, 1996). The LLNL Livermore site would also comply with the BAAQMD's "no net increase" program since any $\mathrm{NO}_{x}$ emissions from the Accelerated Cleanup Initiative project would be offset. This increase in emissions would not be sufficient to cause a reclassification of LLNL Livermore site as a major source of air pollutants.

Impact: Operation of the LLNL Livermore site could increase mobile-source criteria pollutant emissions. This impact is considered less than significant.

The 1992 EIS/EIR presented an estimated increase in mobile-source $\mathrm{NO}_{\mathrm{x}}$ and $\mathrm{CO}$ emissions associated with the LLNL Livermore site. The increase in mobile-source $\mathrm{NO}_{x}$ and $\mathrm{CO}$ emissions was based on an increase in workforce over the ten-year period, resulting in an increase in overall mobile-source emissions. A decrease in workforce has occurred and is expected to remain stable through 2002, therefore the project-related effect is expected to be lower than originally projected and to be within the impacts and emission levels presented in the 1992 EIS/EIR. The currently anticipated project-related change in mobile-source emissions would remain less than the BAAQMD significance thresholds.

Impact: Criteria pollutants would be emitted during construction-related activities at the LLNL Livermore site. This impact is considered less than significant.

The 1992 EIS/EIR concluded that construction-related emissions would contribute to the Livermore area's state-designated nonattainment status for ozone, a significant and unavoidable impact. Recently, basic and enhanced control measures have been promulgated by the BAAQMD. Implementation of these basic and enhanced control measures would reduce this potential impact to a less-than-significant level. 
Impact: Operation of the Accelerated Cleanup Initiative would result in a release of formaldehyde emissions. This impact is considered less than significant.

A 1992 health risk assessment indicated that the LLNL Livermore site did not pose significant carcinogenic, acute, or chronic health risks. The 1992 baseline formaldehyde emissions at the LLNL Livermore site were $16 \mathrm{~kg}$ ( 35 pounds) per day. Formaldehyde emissions from the LLNL Livermore site are currently less than $2 \mathrm{~kg}$ (5 pounds) per day. The Accelerated Cleanup Initiative project would emit less than an additional $0.25 \mathrm{~kg}(0.55$ pound) per year of formaldehyde, which is less than $2 \%$ of the 1992 baseline estimate. Based on the health risk assessment, a $2 \%$ increase would not represent a significant increase in the toxic inventory or pose a significant increase in health effects.

Impact: Operation of the LLNL Livermore site could increase toxic air contaminant and beryllium emissions. This impact is considered less than significant.

The proposed project would not result in a substantially increased health risk because the toxic air contaminants and beryllium emissions would be within the parameters projected in the 1992 EIS/EIR.

\section{SITE 300}

Impact: Operation of Site 300 could generate emissions of criteria pollutants. This impact is considered less than significant.

On the basis of the anticipated change in emission levels, the current anticipated project-related emissions at Site 300 are less than the project-related increases presented in the 1992 EIS/EIR. The currently projected level of emissions would not result in a substantial increase in the severity of impacts compared with those presented in the 1992 EIS/EIR, and is less than the SJVUAPCD significance thresholds.

Impact: Criteria pollutants would be emitted during construction-related activities at Site 300 . This impact is considered less than significant.

The 1992 EIS/EIR concluded that construction-related emissions would contribute to the Livermore area's nonattainment status for ozone, a significant and unavoidable impact. Implementation of construction-related control measures is required for compliance with the SJVUAPCD Regulation VIII, Rule 8020. Implementing these control measures would result in project-related criteria pollutant emissions being below the significance threshold for construction-related emissions; thus, this impact would be less than significant.

Impact: $\quad$ Operation of Site 300 could result in the release of toxic air contaminant and beryllium emissions. This impact is considered less than significant.

Toxic air contaminant and beryllium emissions are within the parameters projected in the 1992 EIS/EIR.

Impact: Operation of Site $\mathbf{3 0 0}$ could result in the release of radionuclides. This impact is considered less than significant. 
No substantial changes related to radionuclides at Site 300 , compared to levels reported in the 1992 EIS/EIR, would be anticipated under the proposed project.

\section{SUMMARY CONCLUSION}

The proposed project is consistent with the air quality analysis presented in the 1992 EIS/EIR and does not involve substantial changes in the project or in the circumstances surrounding the project. In addition, this analysis does not indicate that the project would result in one or more new or substantially more severe significant environmental impacts. There are no mitigation measures or alternatives previously found to be infeasible that would in fact be feasible, nor are there mitigation measures or alternatives that are considerably different from those analyzed in the 1992 EIS/EIR that would substantially reduce one or more significant impacts that have not been adopted. 


\title{
3.10 WATER
}

\section{Subsection: 4.11, Subsection: 5.1.9, Appendix G}

\author{
Standards of Significance: Page 5-105
}

Discussions of the LLNL Livermore site and Site $\mathbf{3 0 0}$ have been combined in this subsection.

\section{SETTING}

\section{LLNL LIVERMORE SITE AND SITE 300}

\section{Surface Water}

Monitoring data obtained since 1992 show no substantial new trends in, or changes to, surface water conditions at LLNL (LLNL, 1992; LLNL, 1993a; LLNL, 1994a; LLNL, 1995b).

Surface water resources in the project area have not changed since certification of the 1992 EIS/EIR. The configuration of surface drainage features at LLNL, such as channels and storm drainage facilities, has generally remained the same.

LLNL continues to monitor water quality data from effluent and other surface sources. The results of regular surface water monitoring are documented in annual reports prepared by LLNL.

\section{Ground Water}

New data developed from regular ground water sampling at LLNL since 1992 indicate sporadic readings of some contaminants, but ground water quality has been improved overall due to ongoing cleanup activities. Ground water quality from the present to the year 2002 can be expected to continue to improve from treatment of known contaminants (LLNL, 1992; LLNL, 1993a; LLNL, 1994a; LLNL, 1995b). Although annual precipitation in recent years has returned to normal levels, there have been no measurable changes in ground water elevations directly attributable to this increase.

\section{Background Ground Water Quality}

Background ground water quality has remained the same since certification of the 1992 EIS/EIR (DOE, 1992b).

\section{Floodplains}

Recent field inspections indicate that the configuration of floodplains in the project area have not changed since certification of the 1992 EIS/EIR. The extent of floodplains onto LLNL property has remained approximately the same as previously documented. 


\section{IMPACTS}

\section{LLNL LIVERMORE SITE AND SITE 300}

Impact: New and proposed construction could result in changes to stormwater runoff and ground water recharge at LLNL Livermore site. This impact is within the parameters of the impact described in the 1992 EIS/EIR.

The proposed project would result in a decreased level of projected construction at the LLNL Livermore site. Therefore, impacts would be within the parameters of the impact described in the 1992 EIS/EIR.

Impact: Water at the Building 834 Complex (Site 300) would be diverted from one watershed to another. This impact is considered beneficial.

Run-on control at the Building 834 Complex would divert a small quantity of water from one watershed to another. The purpose of this project is to control the potential mobilization of existing ground water contamination. This project is described in more detail in Subsection 3.17, "Site Contamination and Remediation." This project would have a beneficial effect on ground water resources.

\section{SUMMARY CONCLUSION}

The proposed project is consistent with the water analysis presented in the 1992 EIS/EIR and does not involve substantial changes in the project or in the circumstances surrounding the project. In addition, this analysis does not indicate that the project would result in one or more new or substantially more severe significant environmental impacts. There are no mitigation measures or alternatives previously found to be infeasible that would in fact be feasible, nor are there mitigation measures or alternatives that are considerably different from those analyzed in the 1992 EIS/EIR that would substantially reduce one or more significant impacts that have not been adopted. 


\subsection{NOISE}

Subsection: 4.12, Subsection: $\mathbf{5 . 2 . 1 1}$

Standards of Significance: Page 5-110

\section{SETTING}

\section{LLNL LIVERMORE SITE}

\section{Federal State, and Local Noise Criteria}

Federal and state noise compatibility guidelines and standards have not changed since certification of the 1992 EIS/EIR. Changes have occurred, however, in local noise guidelines and standards that relate to the LLNL Livermore site.

The City of Livermore General Plan and Noise Element were updated in July 1996. New general plans and noise elements have also been adopted in Alameda County's East County region (County of Alameda, 1994). These new planning guidelines and standards are generally consistent with previously adopted compatibility guidelines and standards and do not change the standards of significance or significance conclusions identified in the 1992 EIS/EIR.

\section{Existing Noise Conditions}

Sources of noise at the LLNL Livermore site include vehicular traffic, mechanical equipment, a high-explosives application facility, and construction and demolition activity. No new sources of noise or unusual changes in the location of noise sources at the site have been identified since certification of the 1992 EIS/EIR (Neuman, 1996). The location of noise sources related to construction activity and facility operation has changed and will continue to change as buildings are demolished and constructed. These activities and sources of noise were addressed in the 1992 EIS/EIR.

Because the workforce at the LLNL Livermore site has decreased, traffic and traffic noise generated by the facility have decreased. Accordingly, traffic noise generated by the facility in the year 2002 will be less than the traffic noise generated in 1992 and will be less than traffic noise projected in the 1992 EIS/EIR. Street traffic and traffic noise near the LLNL Livermore site have stayed about the same or have increased slightly over the past 5 years (Barker, 1996). This can be attributed in part to commercial development between the site and Interstate 580 and ongoing construction of the residential development west of Vasco Road. Projected traffic and traffic noise conditions evaluated in the 1992 EIS/EIR included this commercial and residential development. Current and projected traffic and traffic noise conditions are therefore within the conditions evaluated in the $1992 \mathrm{EIS} / \mathrm{EIR}$.

The number and location of existing and proposed noise-sensitive receptors in the vicinity has generally not changed since the 1992 EIS/EIR was prepared. Additional noise-sensitive receptors are located in the residential development currently being constructed west of Vasco Road. 
Although this development was approved by the City of Livermore in 1989, construction did not commence until recently. Additional residential development has also occurred near East Avenue and Vasco Road. Conditions related to the location of these additional noise-sensitive receptors are considered to be within the bounds of and consistent with conditions evaluated in the 1992 EIS/EIR.

\section{SITE 300}

\section{Federal, State, and Local Noise Criteria}

Federal and state noise compatibility guidelines and standards have not changed since the 1992 EIS/EIR was prepared. Changes in local noise guidelines and standards as they relate to Site 300 are discussed below.

New general plans and noise elements have been adopted in the City of Tracy (City of Tracy and The Planning Center, 1993), San Joaquin County (County of San Joaquin, 1992) since certification of the 1992 EIS/EIR. Except for the City of Tracy, no changes in county or city noise ordinances have occurred since the 1992 EIS/EIR was certified. The City of Tracy adopted a noise control ordinance in April 1994 that specifies 1 -hour average sound level limits for various land use types within the city.

These new planning guidelines and standards are generally consistent with previously adopted compatibility guidelines and standards and do not change the standards of significance or significance conclusions identified in the 1992 EIS/EIR.

\section{Existing Noise Conditions}

Sources of noise at Site 300 include vehicular traffic, mechanical equipment, explosive testing, testing of the Super High Altitude Research Project (SHARP, formerly known as the Cheap Access to Orbit project), the pistol and rifle firing range, and construction activity. No new sources of noise have been identified since certification of the 1992 EIS/EIR (Lane, 1996). The location of noise sources related to construction activity and facility operation has changed and will continue to change as buildings are demolished and constructed. These activities and sources of noise were addressed in the 1992 EIS/EIR.

Outdoor explosive testing is the primary noise-generating activity that can result in distinctly audible blast noise at offsite locations, including the proposed Tracy Hills Specific Plan Area. Outdoor explosive tests are conducted primarily at Buildings 801,850 , and 851; tests conducted at Building 801 are the primary source of noise affecting the offsite locations (White, 1996). The average annual number of outdoor explosive tests that occur at Site 300 has remained relatively constant over recent years; from 238 shots per year in 1992 to between 150 and 250 shots per year in 1996 (Lane, 1996). Approximately $60 \%$ of the shots occur at Building 851 and $40 \%$ occur at Building 801 (Lane, 1996). The total annual average number of shots fired at Site 300 is not expected to change between 1997 and 2002. When the Contained Firing Facility is built, outdoor tests will be eliminated at Building 801 .

The size of the workforce at Site 300 has increased by approximately 47 (23.5\%) since 1992 and is not expected to increase between 1996 and 2002. Traffic and traffic noise generated by the increased workforce are less than the projected increase from the 50 new staff members described in the 1992 EIS/EIR. Development and traffic on roadways around Site 300 have not changed. 
Current and projected traffic and traffic noise conditions near Site $\mathbf{3 0 0}$ are therefore within the conditions evaluated in the 1992 EIS/EIR.

The number and location of existing and proposed noise-sensitive receptors within 1-1.5 miles of the site is unchanged since the 1992 EIS/EIR was prepared and should remain unchanged through the year 2002. Some additional noise receptors (residences) associated with the proposed Tracy Hills Specific Plan may be present before 2002, but their numbers will be fewer than anticipated in the 1992 EIS/EIR because the project has been reduced in size by approximately $40 \%$ (Conant, 1996). These receptors will also be more distant from the borders of Site 300 than was anticipated when the $1992 \mathrm{EIS} / E I R$ was prepared.

\section{IMPACTS}

\section{LLNL LIVERMORE SITE}

Impact: No impact to local guidelines and standards.

Although local planning guidelines have been updated since certification of the $1992 \mathrm{EIS} / E \mathrm{R}$, these new planning guidelines and standards are consistent with previously adopted compatibility guidelines and standards and do not change the less-than-significant noise impacts identified in the 1992 EIS/EIR.

Impact: Changes in traffic noise and construction-related noise could occur. This impact is within the parameters of the impact projected in the $1992 \mathrm{EIS/EIR}$ and is within the parameters of the 1992 EIS/EIR.

Direct traffic noise impacts of the proposed project identified in the 1992 EIS/EIR are unchanged and remain less than significant because trips generated by the workforce have declined at the LLNL Livermore site since 1992 and are expected to remain stable over the next 5 years. Accordingly, traffic-related noise generated by the project would be reduced. Although new construction projects would occur over the next 5 years, construction-related noise impacts would remain less than significant for the reasons stated in the 1992 EIS/EIR.

\section{SITE 300}

Impact: No impact to local guidelines and standards.

Although local planning guidelines have been updated since certification of the $1992 \mathrm{EIS} / \mathrm{EIR}$, these new planning guidelines and standards are consistent with previously adopted compatibility guidelines and standards and do not change the less-than-significant impact identified in the 1992 EIS/EIR.

Impact: Changes in traffic noise, blast noise, and construction-related noise could occur. This impact is within the parameters of the impacts projected in the 1992 EIS/EIR.

Direct traffic noise impacts of the proposed project identified in the 1992 EIS/EIR are expected to decline and remain less than significant because the increase in trips generated by the workforce are below 1992 growth projections and would further decline over the next 5 years. Accordingly, 
traffic-related noise generated by the facilities would be reduced. Although new construction projects would occur over the next five years, construction-related noise impacts would remain less than significant for the reasons stated in the 1992 EIS/EIR.

The proposed Tracy Hills Specific Plan could place new development within 1-1.5 miles of the eastern border of Site 300. A specific plan and associated EIR for this project is expected for release to the public in late 1996 (Conant, 1996). The current proposed plan shows potential noise receptors as being more distant from the site than previously proposed. This project and other potential projects in the area are described in the 1992 EIS/EIR as local projects that would contribute to cumulative impacts and potentially be affected by noise from explosive testing at Building 801 and testing of Super High Altitude Research Project (SHARP). However, as discussed in the 1992 EIS/EIR, the blast noise impacts from explosive testing at Building 801 will be reduced if the Contained Firing Facility is built. Some explosive tests too large to be conducted at the facility would be shifted to Buildings 850 and 851 , which are further away from potential noise-sensitive areas to the east. Explosive tests too large for Site 300 would be conducted at the Nevada Test Site. No new or changed impacts associated with SHARP would occur. In summary, the proposed action would not result in any change in explosive testing activity or impacts relative to those addressed in the 1992 EIS/EIR.

\section{SUMMARY CONCLUSION}

The proposed project is consistent with the noise analysis presented in the 1992 EIS/EIR and does not involve substantial changes in the project or in the circumstances surrounding the project. In addition, this analysis does not indicate that the project would result in one or more new or substantially more severe significant environmental impacts. There are no mitigation measures or alternatives previously found to be infeasible that would in fact be feasible, nor are there mitigation measures or alternatives that are considerably different from those analyzed in the 1992 EIS/EIR that would substantially reduce one or more significant impacts that have not been adopted. 


\title{
3.12 TRAFFIC AND TRANSPORTATION
}

\author{
Subsection: 4.13, Subsection: 5.1.11, Appendix K
}

Standards of Significance: Page 5-121

SETTING

\section{LLNL LIVERMORE SITE}

Local Planning Guidelines

Since the 1992 EIS/EIR was certified, general plans have been updated for Alameda County's East County region (County of Alameda, 1994) and the City of Livermore (City of Livermore, 1996a). Guidelines for acceptable level of service are unchanged from previous plans.

\section{Regional and Local Circulation Systems}

Roads providing access to the LLNL Livermore site have changed since the 1992 EIS/EIR was certified. Vasco Road near the LLNL Livermore site was widened from two to four lanes, tum lanes have been added at Greenville Road, and a new signal has been added at Eastgate Way (Barker, 1996). Of the two regional transportation systems discussed in the 1992 EIS/EIR, only the Bay Area Rapid Transit (BART) extension to Dublin and Pleasanton is under construction. Service is expected to begin in late 1996. Plans for the Mid-State Tollway have been delayed indefinitely. As stated in the 1992 EIS/EIR, the BART extension is not expected to have a substantial effect on traffic at key intersections or roadways near the LLNL Livermore site because of the distance from the key roadways and intersections to the BART facility. The Altamont Rail Line, a new regional transportation project currently being proposed, would involve use of a rail line from Stockton to San Jose. The rail line passes through Livermore and potentially could reduce traffic in the area if commuters chose to ride the train instead of driving to the site (Barker, 1996).

\section{Local Traffic Conditions}

Traffic generated by the LLNL Livermore site has decreased because the size of the workforce has decreased since 1992. The workforce is projected to continue to decrease through the year 2002. Accordingly, traffic generated by the workforce in 2002 will be less than traffic generated in 1992 and will be less than traffic projected in the 1992 EIS/EIR. Construction of new facilities, including NIF, would result in short-term increases in traffic, but the increases are within the scope of increases addressed in the 1992 EIS/EIR.

Although overall trip generation has decreased, the number of annual shipments of solid low-level waste from the LLNL Livermore site and Site 300 to the Nevada Test Site is expected to be greater than the quantity projected in the 1992 EIS/EIR. Subsection 3.15, "Waste Management," of this addendum discusses this issue in more detail. This increase corresponds to less than 320 additional shipments per year or less than one additional shipment per day on average, a negligible 
increase relative to the number of vehicles that travel on nearby roadways. This small increase would be offset by the reduction in traffic attributable to the diminished workforce.

Street traffic in the vicinity of the LLNL Livermore site has generally stayed about the same or has increased slightly over the past five years (Barker, 1996) This can be attributed in part to commercial development between the LLNL Livermore site and Interstate 580 and ongoing construction of the residential development west of Vasco Road. Projected traffic conditions evaluated in the 1992 EIS/EIR included this commercial and residential development. Although some land use and zoning designations in surrounding areas have changed since 1992, which would result in more intense development and more traffic than was envisioned in the 1992 EIS/EIR, projected traffic conditions are considered to be within the parameters evaluated in the 1992 EIS/EIR. The increases in traffic associated with changed uses are offset by reductions in local traffic generated by the LLNL Livermore site workforce.

\section{Alternate Modes of Transportation}

As a result of implementation of the Transportation Systems Management Program required by the 1992 EIS/EIR, changes in the use of alternate modes of transportation, such as buses and ridesharing, have occurred since the 1992 EIS/EIR was certified (Miller, 1995). Ridesharing and transit use has doubled over the last five years (Miller, 1995). Commuter bus service from San Joaquin Valley locations have increased from two buses per day to seven. Also, an independent bus service began operating between Modesto and the LLNL Livermore site.

\section{SITE 300}

\section{Local Planning Guidelines}

Since the 1992 EIS/EIR was certified, general plans have been updated for the City of Tracy (City of Tracy and The Planning Center, 1993), San Joaquin County (County of San Joaquin, 1992), and Alameda County's East County region (County of Alameda, 1994). Guidelines for acceptable levels of service are unchanged from previous plans.

\section{Regional and Local Circulation Systems}

Roads providing access to Site 300 are unchanged since the 1992 EIS/EIR was certified (Barker, 1996). Because of the distance from Site 300 to the BART extension, traffic at key intersections or roadway segments near Site 300 will not be affected by the extension. The Altamont Rail Line, a new regional transportation project currently being proposed, would involve use of a rail line from Stockton to San Jose (Barker, 1996). Because of the remote location of Site 300 , it is unlikely that operation of this rail line would reduce traffic in the vicinity of Site 300.

\section{Local Traffic Conditions}

The size of the workforce at Site 300 has increased by approximately $47(23.5 \%)$ since 1992 and is not expected to increase between 1996 and 2002. Traffic generated by the workforce has increased proportionately. This increase is less than the projected increase of 50 staff members described in the 1992 EIS/EIR. Construction of new facilities, including the Contained Firing Facility, would result in short-term increases in traffic, but these increases in construction-related traffic are within the scope of increases addressed in the 1992 EIS/EIR. 
Traffic on roadways around Site 300 have not changed since the 1992 EIS/EIR was certified. Current and projected traffic conditions near Site 300 are therefore within the parameters evaluated in the 1992 EIS/EIR.

\section{Alternate Modes of Transportation}

Implementation of the Transportation Systems Management Program has resulted in increased ridesharing at Site 300 (Miller, 1995). Because of the remoteness of the site and the relatively small number of employees, there is no public transit service to Site 300 .

\section{IMPACTS}

\section{LLNL LIVERMORE SITE}

Impact: No impact to local traffic and transportation planning guidelines.

Although local planning guidelines have been updated since the 1992 EIS/EIR was certified, guidelines on acceptable level of service are unchanged. Accordingly, the standards for significance identified in the 1992 EIS/EIR are unchanged.

Impact: Changes in traffic, parking, and other transportation-related impacts could occur. This impact is within the parameters of the impacts projected in the 1992 EIS/EIR.

Direct traffic, parking, and transportation-related impacts identified in the 1992 EIS/EIR are unchanged and remain less than significant because trips generated by the workforce have declined at the LLNL Livermore site since 1992 and should stabilize over the next five years. Although new construction projects, including NIF, could occur over the next five years, construction-related traffic impacts would remain within the parameters described in the 1992 EIS/EIR.

Impact: Shipments of low-level waste to the Nevada Test Site would increase. This impact is considered less than significant.

As discussed above and in Subsection 3.15, "Waste Management," the total number of shipments of low-level waste from the LLNL Livermore site and Site 300 to the Nevada Test Site is expected to increase above the quantity predicted in the 1992 EIS/EIR. However, the total number of annual shipments, and the increase in shipments, is negligible compared to existing and projected traffic on nearby roadways and Interstate 580 . The increase in shipments would therefore have a lessthan-significant impact on operation of nearby intersections or roadways. Although the increase in shipments may increase the potential for accidents, safety procedures, including LLNL (both sites) safety procedures and state and federal requirements (13 California Code of Regulations [CCR] 1-6.5 and 49 Code of Federal Regulations [CFR] 100-179, 393) will be implemented to address potential safety issues associated with shipment of waste materials and will reduce this potential impact to a less-than-significant level. 


\section{SITE 300}

Impact: No impact to local traffic and transportation planning guidelines.

Although local planning guidelines have been updated since the 1992 EIS/EIR was prepared, guidelines on acceptable level of service are unchanged. Accordingly, the standards for significance identified in the $1992 \mathrm{EIS/EIR}$ are unchanged.

Impact: Changes in traffic, parking, and other transportation-related impacts could occur. This impact is within the parameters of the impacts projected in the 1992 EIS/EIR.

Direct traffic, parking, and transportation-related impacts identified in the 1992 EIS/EIR are unchanged and remain less than significant because the current number of trips generated by the workforce are well below 1992 growth projections and would be further reduced over the next five years. Although new projects, including the Contained Firing Facility, could be constructed over the next five years, construction-related traffic impacts would remain within the parameters described in the 1992 EIS/EIR.

Impact: Shipments of low-level waste to the Nevada Test Site would increase. This impact is considered less than significant.

As discussed above and in Subsection 3.15, "Waste Management," the total number of shipments of low-level waste to the Nevada Test Site from the LLNL Livermore site and Site 300 is expected to exceed the quantity predicted in the 1992 EIS/EIR. However, the total number of annual shipments, and thus the increase in shipments, is negligible compared to traffic on nearby roadways and Interstate 580. The increase in shipments would therefore have a less-thansignificant impact on operation of nearby intersections or roadways. Although the increase in shipments may increase the potential for accidents, safety procedures, including LLNL (both sites) safety procedures and state and federal requirements (13 CCR 1-6.5 and 49 CFR 100-179, 393) will continue to be implemented to address potential safety issues associated with shipment of waste materials and will reduce this impact to a less-than-significant level.

\section{SUMMARY CONCLUSION}

The proposed project is consistent with the traffic and transportation analysis presented in the 1992 EIS/EIR and does not involve substantial changes in the project or in the circumstances surrounding the project. In addition, this analysis does not indicate that the project would result in one or more new or substantially more severe significant environmental impacts. There are no mitigation measures or alternatives previously found to be infeasible that would in fact be feasible, nor are there mitigation measures or alternatives that are considerably different from those analyzed in the 1992 EIS/EIR that would substantially reduce one or more significant impacts that have not been adopted. 


\subsection{UTILITIES AND ENERGY}

Subsection: 4.14, Subsection: 5.1 .12

Standards of Significance: Page 5-137

SETTING

\section{LLNL LIVERMORE SITE}

\section{Water Consumption}

The 1992 EIS/EIR estimated that 1991 water consumption at the LLNL Livermore site was 239.77 million gallons per year, and that it would increase to 261.3 million gallons by the year 2002 . Actual annual water consumption at the LLNL Livermore site went from 190 million gallons in 1991 to 229 million gallons in 1994 (Farrell, 1996). The overall trend in water consumption since 1991 has leveled off and should remain within the parameters predicted in the 1992 EIS/EIR for the 1992-2002 period.

\section{Electricity Consumption}

The 1992 EIS/EIR estimated that 1991 electrical consumption at the LLNL Livermore site was 341.5 million kilowatt hours, and that it would increase to 380 million kilowatt hours by the year 2002. The actual annual average electrical consumption trend has decreased from 319 million kilowatt hours in 1992 to 294 million kilowatt hours in 1995 (Allen, 1996) and should remain within the parameters predicted in the 1992 EIS/EIR for the 1992-2002 period, with presently projected projects and future building utilizations.

\section{Fuel Consumption}

\section{Gasoline, Diesel, and Propane Consumption}

Gasoline, diesel fuel, and propane are consumed at the LLNL Livermore site. The five-year average annual usage levels cited in the 1992 EIS/EIR are 496,200 gallons per year of gasoline, 86,600 gallons per year of diesel fuel, and 10,400 gallons per year of propane. Since 1992, annual use of these combined fuels has decreased by approximately $37.5 \%(309,824$ gallons per year of gasoline; 34,956 gallons per year of diesel; and 10,000 gallons per year of propane) and should remain within the parameters predicted in the 1992 EIS/EIR for the 1992-2002 period (Ruiz, 1996; Farrell, 1996).

\section{Natural Gas Consumption}

Natural gas consumption at the LLNL Livermore site fluctuates annually. The 1986-1990 five-year actual annual average consumption described in the 1992 EIS/EIR was 3.69 million therms. The actual annual average between 1991 and 1995 was 4.73 million therms (Parisotto, 1996), which represents a $28.2 \%$ increase in the amount predicted in the $1992 \mathrm{EIS/EIR.} \mathrm{The} \mathrm{increase} \mathrm{is}$ 
attributable in part to the decommissioning of temporary building structures heated and cooled with electric-powered pumps. Many of the occupants of these temporary buildings have relocated to permanent buildings serviced by natural gas boilers. This increased trend in natural gas consumption has been partially offset by a decreased trend in electrical usage. Additional service requirements for natural gas not accounted for by the LLNL Livermore site gas meter include two new, small lines (less than .004 million therms) (Farrell, 1996) that service the natural gas vehicle station (OS621) and the Mail Room (O41) (Faubion, 1996).

Since the proposed project would increase the gross square footage, and it has been assumed that gas consumption is proportional to gross square footage, it may be assumed that gas consumption would continue to increase. Additionally, the proposed project calls for additional permanent buildings with either new boilers or boiler replacements and skid-mounted boilers for the projects like the Accelerated Cleanup Initiative. These boilers would also consume natural gas. Therefore, natural gas consumption should continue to increase over the next five years and would remain above the growth level predicted in the 1992 EIS/EIR for the 1992-2002 period. Pacific Gas and Electric Company routinely evaluates the capacity of natural gas systems for new projects (Faubion, 1996).

\section{Sewer Discharge}

The City of Livermore's sewage treatment facility was upgraded in 1994 as projected in the 1992 EIS/EIR (Metal, 1996). The sewer discharges from the LLNL Livermore site have varied from 90.1 million to 111.4 million gallons per year, and have decreased slightly over the last four years, remaining within the parameters projected in the 1992 EIS/EIR for the 1992-2002 period (Farrell, 1996).

\section{SITE 300}

\section{Water Consumption}

Site 300 will be connected to the City of San Francisco's Hetch Hetchy water supply system as predicted in the 1992 EIS/EIR. The 1992 EIS/EIR predicted water consumption at Site 300 to be 30 million gallons per year in 1992, rising to 32.7 million gallons in 2002 . Actual water consumption peaked in 1992 at 34 million gallons per year and has declined to 23 million gallons per year in 1995 (Paukert, 1996). Water consumption at Site 300 is projected to remain within the parameters predicted in the 1992 EIS/EIR for the 1992-2002 period.

\section{Electricity Consumption}

Annual use of electricity at Site 300 has increased slightly (one-half of one percent) (Allen, 1996) as compared with the 1990 base electrical use at Site 300 cited in the 1992 EIS/EIR. With presently projected projects and future building utilization through the year 2002, electricity consumption should remain within the parameters predicted for the 1992-2002 period.

\section{Fuel Consumption}

\section{Fuel Oil Consumption}

Combined gasoline and diesel consumption has decreased from the amount predicted in the 1992 EIS/EIR (78,000 gallons per year) to approximately 70,500 gallons per year, primarily because the 
largest boiler, which operated on diesel at Site 300 (Building 827 ) was replaced by six electric boilers (Ruiz, 1996; Mahan, 1996). Propane and natural gas are not consumed at Site 300.

\section{Sewer Discharge}

Sewage discharge and handling practices have not changed at Site 300 since certification of the 1992 EIS/EIR (Hill, 1996). Because some of the discharges are to septic tanks and leach fields or cesspools at individual building locations, total actual discharge levels are unknown. The 1992 EIS/EIR estimated discharges to the asphalt membrane-lined oxidation pond in the General Services Area to be 1.3 million gallons per year. Because the gross square footage in the General Services Area has remained constant, a change in the discharge rate to the asphalt membranelined oxidation pond is not expected.

\section{IMPACTS}

Impact: No impact to the consumption of natural gas.

Annual consumption of natural gas at the LLNL Livermore site has increased $28.2 \%$ on average since 1992. Although this increase is above the growth level predicted in the 1992 EIS/EIR over the 1992-2002 period, there is no change to the service requirement of natural gas from the distributing utility, Pacific Gas and Electric Company (i.e., the gas line diameter and pressure remained the same and no new infrastructure is required) (Faubion, 1996). Pacific Gas and Electric Company has sufficient resources to maintain this supply. The increased consumption of natural gas for space-heating purposes has been partially offset by a decrease in electrical usage over the same period. Therefore, this is a less-than-significant impact.

\section{SUMMARY CONCLUSION}

The proposed project is consistent with the utilities and energy analysis presented in the 1992 EIS/EIR and does not involve substantial changes in the project or in the circumstances surrounding the project. In addition, this analysis does not indicate that the project would result in one or more new or substantially more severe significant environmental impacts. There are no mitigation measures or alternatives previously found to be infeasible that would in fact be feasible, nor are there mitigation measures or alternatives that are considerably different from those analyzed in the 1992 EIS/EIR that would substantially reduce one or more significant impacts that have not been adopted. 


\title{
3.14 MATERIALS MANAGEMENT
}

\author{
Subsection: 4.15.1, Subsection: 5.1 .13
}

Standards of Significance: Page 5-152

\section{SETTING}

A wide variety of materials are routinely handled and used during normal LLNL (both sites) operations with negligible consequences to workers, the public, or the environment. Modifications to regulatory requirements relevant to materials management since certification of the 1992 EIS/EIR focus on increased documentation and reporting requirements.

\section{LLNL LIVERMORE SITE}

\section{Radioactive and Hazardous Materials}

\section{Radionuclide Inventories}

Because the quantities of many radionuclides maintained and used in research and development activities at LLNL Livermore site may vary substantially over time, the following description identifies administrative limits for selected buildings. Administrative limits are criteria establishing the maximum quantities of selected materials that may be present in an operation or building based on need or other safety requirements. The presentation of administrative limits also provides a means to report a maximum possible quantity of a material without identifying the actual quantity of that material, which may be classified. The actual quantity or inventory of a material will never be greater than its administrative limit.

As discussed in the 1992 EIS/EIR, a goal was established to reduce the plutonium administrative limit of Building 332 at the LLNL Livermore site from $700 \mathrm{~kg}$ to $200 \mathrm{~kg}$ (DOE, 1992a). Related plutonium inventory reductions, which were scheduled for completion during fiscal year 1993, were accomplished in part through shipments to offsite DOE facilities. Although approximately half of the excess material was relocated, DOE facilities offsite were unable to accept all materials and will be unable to accept additional material until after the year 2000 . Excess plutonium remaining in Building 332 was packaged and is now being stored until shipments can be resumed (Ives, 1996) or DOE designates an alternate destination. The administrative limit for Building 332 was not reduced as had been anticipated in the 1992 EIS/EIR and remains at $700 \mathrm{~kg}$. LLNL Livermore site is currently preparing to stabilize and repackage the remaining inventory in accordance with DOE Standard 3013-94, as suggested in Defense Nuclear Facility Safety Board Recommendation 94-1. Within five years of October 1996, all of the remaining materials will be repackaged in accordance with this DOE standard.

LLNL proposes to modify the administrative limits for tritium onsite for increased flexibility in storing materials in a single building. This would improve the staging of experiments involving tritium and to increase the efficiency of operations. 
The 1992 EIS/EIR tritium administrative limits allowed for no more than 5 grams $(\mathrm{g})$ of tritium in any one facility and no more than $10 \mathrm{~g}$ of tritium to be divided between three buildings (Buildings 298, 391, and 331). The administrative limit of tritium would be $10 \mathrm{~g}$ in any one building with the sitewide administrative limit remaining at $10 \mathrm{~g}$.

The quantity of material at risk would remain the same as presented in the 1992 EIS/EIR and is $3.5 \mathrm{~g}$. Therefore, the impacts remain the same.

The self-imposed facility limit for natural and depleted uranium in Building 493 at the LLNL Livermore site was established as $80,000 \mathrm{~kg}$ in the 1992 EIS/EIR. As the AVLIS Project moves into the pilot operations phase, the self-imposed facility limit for the Separator Demonstration Facilities Complex, including Building 493 , would increase to $160,000 \mathrm{~kg}$. The safety-based combined administrative limit for Buildings 490,491 , and 493 , which is based on a maximum $5 \%$ weight uranium-235, will not change.

\section{Chemical Inventories}

In late 1993, LLNL began using the ChemTrack chemical tracking database (LLNL, 1996c). ChemTrack is designed to be updated when chemical containers are received onsite, relocated between onsite facilities, or designated for disposal, and during periodic audits. Table 3.14-1 presents the inventory as of 1992 and 1996 and the estimated inventory projected to 2002 from 1996 data.

Table 3.14-1. Current and Projected Chemical Quantities at the LLNL Livermore Site"

\begin{tabular}{||c|c|c|c||}
\hline Chemical & $\begin{array}{c}\text { 1992 Reported } \\
\text { (1992) }\end{array}$ & $\begin{array}{c}\text { 1996 Actual } \\
\text { (1996) }\end{array}$ & $\begin{array}{c}\text { 2002 Projected } \\
\text { (1996) }\end{array}$ \\
\hline Liquid (gallons) & 210,000 & 139,000 & 144,200 \\
Solidc (pounds) & $2,300,000$ & $1,305,500^{d}$ & $1,353,800$ \\
\hline
\end{tabular}

auantities are rounded to the nearest hundred units.

b Data are primarily summaries of information presented in the 1996 Main Site Hazardous Materials Business Plan. Specifically, the data present combined quantities of Superfund Amendments and Reauthorization Act (SARA) 302 Extremely Hazardous Materials in excess of 1 pound, and all other chemicals in excess of 500 pounds, 55 gallons, 200 cubic feet, or applicable federal Threshold Planning Quantities, whichever is least. These numbers include Freon-113, hydrochloric acid, and nitric oxide, which were not included in the 1996 Main Site Hazardous Materials Business Plan.

c 1992 EIS/EIR estimates for compressed gas at the LLNL Livermore site were included in solid material estimates. 1996 EIR Addendum data are presented in a consistent manner.

d Reduction primarily attributed to removing sand from inventory.

Sources: Harris, 1996; LLNL, 1996c; LLNL, $1996 \mathrm{i}$. 
Based on a comparison of the selected 1992 EIS/EIR data with ChemTrack data, current projections for material quantities in 1997-2002 remain within the 1992 EIS/EIR projections.

The effects of existing and potential future onsite and offsite shipments of chemicals and radioactive materials at LLNL Livermore site are similar to the 1992 EIS/EIR baseline.

\section{Controlled Materials}

No known or anticipated changes in controlled materials management that are outside the bounds of the 1992 EIS/EIR have occurred at the LLNL Livermore site since certification of the 1992 EIS/EIR.

\section{Nonhazardous Materials}

No known or anticipated changes in nonhazardous materials management that are outside the bounds of the 1992 EIS/EIR have occurred at the LLNL Livermore site since certification of the 1992 EIS/EIR.

\section{Decontamination of Equipment and Facilities}

No known or anticipated changes in operational decontamination of equipment and facilities that are outside the bounds of the 1992 EIS/EIR have occurred at the LLNL Livermore site since certification of the 1992 EIS/EIR.

\section{Excess Properties Salvage and Reclamation}

The DOE/UC contract extension stipulates that LLNL shall annually evaluate and prioritize sitespecific pollution prevention opportunities and establish milestones and other criteria to measure progress for each opportunity. DOE has set the following goals for LLNL to achieve by the end of calendar year 1999 (all goals are measured relative to a 1993 baseline year):

- Reduce routine operational radioactive, low-level mixed, and hazardous waste generation by $50 \%$ for existing operations.

- Reduce routine operational sanitary waste generation by $33 \%$, and divert for recycling $33 \%$ of sanitary waste from all operations.

- $\quad$ Reduce by $50 \%$ chemical releases and transfers for treatment and disposal that are subject to Section 313 of the Emergency Planning and Community Right-to-Know Act.

- Evaluate vendor and contractor procurements considering their use of recycled products.

Implementation of programs to address these goals should result in substantial reduction of waste, as well as increases in salvage and reuse of material. For example, the ChemTrack system offers a chemical locating service and the Chemical Exchange Warehouse, facilitates the transfer of unused chemicals. Both services help minimize the amount of chemicals that would otherwise remain unused in inventory or become waste. 


\section{SITE 300}

\section{Radionuclide Inventories}

Although tritium has not been used in tests at Site 300 in recent years, the administrative limit for the use of small quantities of tritium in tests at the firing table remains $0.02 \mathrm{~g}$ (LLNL, 1996k). This same limit has been reflected in the Contained Firing Facility discussion in the Stockpile Stewardship and Management PEIS (DOE, 1996c).

\section{Chemical Inventories}

Table 3.14-2 presents current and projected quantities of chemicals as estimated in 1992 and 1996.

Table 3.14-2. Current and Projected

Chemical Quantities at Site 300 *

\begin{tabular}{||l|c|c|c|}
\hline \multicolumn{1}{|c|}{ Chemical } & $\begin{array}{c}\text { 1992 Reported } \\
\text { (1992) }\end{array}$ & $\begin{array}{c}\text { 1996 Actual } \\
\text { (1996) }\end{array}$ & $\begin{array}{c}\text { 2002 Projected } \\
\text { (1996) }\end{array}$ \\
\hline \hline Liquid (gallons) & 84,000 & 86,100 & 81,000 \\
Solid (pounds) & 100,000 & 7,500 & 7,100 \\
$\begin{array}{c}\text { Compressed Gas } \\
\text { (cubic feet) }\end{array}$ & $1,900,000$ & 448,100 & 421,700 \\
\hline
\end{tabular}

Quantities are rounded to the nearest hundred units.

b Data in the table are summaries of information presented in the 1996 Site 300 Hazardous Materials Business Plan. Specifically, the data present combined quantities of SARA 302 Extremely Hazardous Materials in excess of one pound, and all other chemicals in excess of 500 pounds, 200 cubic feet, 55 gallons, or applicable federal Threshold Planning Quantities, whichever is least.

Sources: Harris, 1996; LLNL, 1996c; LLNL, $1996 f$.

Both the 1996 actual (1996) and 2002 projected (1996) quantities for solids at Site 300 are below the 1992 EIS/EIR combined actual and projected values, which totaled 109,000 pounds. There has been no increase in material quantity or storage capacity. In addition to the quantities of materials reported above, the ChemTrack system now accounts for approximately 100,000 pounds of explosives and 310,000 pounds of lead bricks, both of which were present at Site 300 in 1992 but were not included in the inventories developed at that time.

Anticipated solid, liquid, and compressed gas material quantity changes from 1992 through 2002, other than those for explosives and lead bricks, are within the limits established in the 1992 EIS/EIR. 


\section{Controlled Materials}

Construction of two new explosives storage magazines is proposed to add capacity to ensure that Site 300 can meet mission requirements in compliance with applicable explosive storage requirements. Five explosives storage magazines were converted to store explosives waste up to one year.

\section{Nonhazardous Materials}

No known or anticipated changes in nonhazardous materials management that are outside the bounds of the 1992 EIS/EIR have occurred at Site 300 since certification of the 1992 EIS/EIR.

\section{Decontamination of Equipment and Facilities}

No known or anticipated changes in operational decontamination of equipment and facilities that are outside the bounds of the 1992 EIS/EIR have occurred at Site 300 since certification of the 1992 EIS/EIR.

\section{Excess Properties Salvage and Reclamation}

The discussion above for the LLNL Livermore site also pertains to Site 300 .

\section{IMPACTS}

\section{LLNL LIVERMORE SITE}

Impact: No impact to plutonium management.

The materials management changes at the LLNL Livermore site include continued storage of plutonium in Building 332. Materials management systems and processes are anticipated to continue as predicted in the 1992 EIS/EIR between 1996 and 2002 . The changes identified above do not result in new significant impacts or increased severity of previous impacts on materials management.

Impact: No impact to uranium management.

The increase in the self-imposed storage limit for natural and depleted uranium would not have a significant impact on materials management. Adequate storage space currently exists and procedures are already in place to handle the increased inventory. The new storage limit does exceed existing quantity of stored uranium stated in the 1992 EIS/EIR, but it does not have more than negligible effects on materials management systems. The changes identified above do not result in new significant impacts nor increased severity of previously identified impacts on materials management. 
SITE 300

Impact: No impact to materials management systems and processes.

\section{SUMMARY CONCLUSION}

The proposed project is consistent with the materials management analysis presented in the 1992 EIS/EIR and does not involve substantial changes in the project or in the circumstances surrounding the project. In addition, this analysis does not indicate that the project would result in one or more new or substantially more severe significant environmental impacts. There are no mitigation measures or alternatives previously found to be infeasible that would in fact be feasible, nor are there mitigation measures or alternatives that are considerably different from those analyzed in the 1992 EIS/EIR that would substantially reduce one or more significant impacts that have not been adopted. 


\title{
3.15 WASTE MANAGEMENT
}

\author{
Subsection: 4.15.2, Subsection: 5.1 .13
}

Standards of Significance: Page 5-152

Discussions of the LLNL Livermore site and Site 300 have been combined in this subsection.

\section{SETTING}

\section{LLNL LIVERMORE SITE AND SITE 300}

The Hazardous Waste Management Division within the Environmental Protection Department of the Plant Operations Directorate continues to manage waste-handling facilities and activities at the LLNL Livermore site (as well as Site 300 ). Several programmatic changes have been implemented since certification of the 1992 EIS/EIR, including initiation of a low-level waste (LLW) certification program and a legacy waste work-off (inventory reduction) program.

In response to the issuance of new waste acceptance criteria (NVO-325) by the Nevada Test Site, LLNL finalized a LLW certification program in 1993 and resumed shipments to the Nevada Test Site in November of that year. Nearly all LLW is now certified and can be shipped to the Nevada Test Site. Implementation of waste certification and the resumption of shipments to the Nevada Test Site caused a spike in solid LLW shipments in 1994-1995 (see "Solid Low-Level Radioactive Waste" below), which was in part attributable to the disposal at the Nevada Test Site of radioactive debris from Site 300 firing tables. The debris was held until approval to ship was received from DOE Nevada Operations Office (DOE/NV).

LLNL continues to store low-level, low-level mixed, transuranic (TRU), and TRU-mixed waste consisting of waste streams that cannot be accepted in their current form by commercial or federal facilities for offsite treatment, storage, or disposal. A project has been initiated to characterize and/or modify these waste forms to facilitate offsite treatment, storage, or disposal (thus reducing the onsite inventory). These inventory work-off efforts are partially governed by commitments identified in the draft LLNL Site Treatment Plan (the plan addresses mixed waste only) (DOE, 1995a). As a result of the work-off project, the trend toward a reduced legacy waste inventory will continue. TRU and TRU-mixed waste, however, will continue to accumulate onsite until the Waste Isolation Pilot Plant (WIPP) opens or another option is approved by DOE.

A draft Site Treatment Plan was prepared pursuant to of the Federal Facility Compliance Act, which was passed after certification of the 1992 EIS/EIR. The act required federal facilities that generated mixed waste for which no treatment capacity existed to prepare site treatment plans with schedules for development of innovative technologies or other means to eventually treat (consistent with Resource Conservation and Recovery Act (RCRA) treatment standards related to land disposal restrictions) and dispose of these wastes. The act also provided relief from storage limitations while federal facilities prepared these plans and schedules. With the consent of the 
State, the Laboratory has already begun treatment and disposal of mixed waste consistent with the draft Site Treatment Plan that is still being reviewed.

In addition to the certification program and offsite shipment of LLW that had accumulated during 1990-1993, achievements in waste work-off included implementation of improved waste characterization and tracking tools, and increased use of commercial permitted offsite vendors to treat and dispose of waste.

The LLNL Livermore site has begun construction of the Decontamination and Waste Treatment Facility (DWTF) that was a proposed project in the 1992 EIS/EIR (only those portions of the facility that do not require an RCRA permit or are currently under construction). Although the project has changed from its initial inception, modifications have been made primarily to accommodate operational needs and funding circumstances. The most significant change involved deletion of the Mixed Waste Management Facility portion of the facility because DOE canceled the funding for this portion of the project in 1996. A complete description of the DWTF can be found in the 1996 DOE environmental assessment (DOE, 1996d). The DOE published a Finding of No Significant Impact on June 12, 1996, for this project (DOE, 1996e).

Additionally, LLNL has submitted revised RCRA Part B permit application to the California Department of Toxic Substances Control in June 1996 (LLNL, 1996h). The permit application discusses LLNL's intent to consolidate treatment units in the DWTF and the subsequent closure of Area 514. Also planned are the use of a new container storage area at Building 280 (to be used for "high activity" [greater than 6 curies per container] waste) and the subsequent closure of the Building 233 Container Storage Unit. LLNL (both sites) expects to receive a permit to operate the facilities and their subunits by the end of 1997.

The overall effect of these changes will be an enhanced treatment and storage capacity, including the ability to treat a greater variety of wastes. The overall effect of the enhanced treatment and storage capacity will result in the ability to manage the backlog of legacy waste while properly managing newly generated waste. Table 3.15-1 provides a comparison of 1992 treatment and storage capacities (RCRA-regulated wastes only) with those that will be available after construction of the DWTF, modification of Building 280, and closure of Area 514 and Building 233 (LLNL, 1991; LLNL, 1996h).

Table 3.15-1. Changes in Storage and Treatment Capacities

\begin{tabular}{||l|c|c|}
\hline & 1991 Part A Permit & 1996 Part A Permit \\
\hline Storage (gallons) & 807,775 & $1,191,190$ \\
\hline Treatment (pounds/day) & 332,816 & 681,250 \\
\hline
\end{tabular}

LLNL has instituted a waste minimization program designed to reduce routine generation of all waste types (except sanitary waste) by $50 \%$ by the year 2000 (using 1993 generation rates as a baseline, and discounting contributions from new projects). LLNL's operating contract with DOE now includes performance measures for waste minimization and pollution prevention that describe incremental accomplishments intended to facilitate achievement of this goal. Recent achievements in waste minimization include installation of online recycling systems, use of more environmentally friendly cleaning chemicals, and increased usage of offsite recycling vendors. 
Proposed projects that will contribute to future waste generation prior to the year 2002 and that have a significant likelihood of implementation are discussed below:

- The AVLIS Program is moving from the PEV phase of routine operations through the IPD and into Pilot Operations by 1999. IPD would double the ongoing (PEV-phase) rate of solid LLW generation (mostly in 1997). Although Pilot Operations would replace IPD in 1999, this last phase represents a scale-up of operations and is expected to more than double the current PEV-phase generation rate of solid LLW. Other waste streams, especially liquid LLW, would also be affected (although to a lesser degree) by scaled-up operations in laser isotopic separation (USEC, 1996). Other, nonradioactive isotopes may be separated in the AVLIS Program. Lead and thallium may be processed in fiscal year 1998 and beyond. Quantities processed could be as much as $\mathbf{5 0}$ metric tons per year. Responsibility for the AVLIS Program is currently in transition. Operated at LLNL under the sponsorship of USEC, a quasi-governmental entity, full transition to privatization of the AVLIS Program is scheduled for early 1997.

Wastes generated at Site 300 continue to be managed as described in the 1992 EIS/EIR. Although proposed facility and operational changes would affect waste management and generation rates, these changes do not substantially alter impacts described in the 1992 EIS/EIR. The overall effect of these changes would be to reduce routine waste generation, although some of them may result in significant, one-time increases in waste generation. These changes are described below:

- LLNL proposes to permit, construct, and operate the Explosive Waste Treatment Facility at Site $\mathbf{3 0 0}$ to treat bulk explosives, explosives pieces or powders from experiments and machining, clarifier filter bags containing explosives waste, and explosives-contaminated items. The 1992 EIS/EIR indicated that only dry solid wastes would be treated at the facility, whereas current plans include clarifier fines (wet sludges that result from the process of removing explosive particulates from processing water) and liquid explosives. A comprehensive discussion of the wastes to be treated and the proposed operating criteria are available in the RCRA Part B permit application; a more thorough discussion of the proposed facility and potential impacts is available in the DOE NEPA environmental assessment for which a Finding of No Significant Impact has been published (DOE, 1995b).

- As proposed in the 1992 EIS/ EIR and described in more detail in the DOE Stockpile Stewardship and Management PEIS, LLNL proposes to construct and operate the Contained Firing Facility at Site $\mathbf{3 0 0}$ for containment of some explosive test experiments that are currently conducted outdoors on the firing pad at Building 801 . Because operation of the Contained Firing Facility would eliminate the need to use the firing table at Building 801 , the total amount of solid waste (especially LLW) generated annually would be less than that currently being generated at Building 801 . Construction of the facility, however, may cause a one-time increase (in 1996-1997) in generation of LLW because soils excavated during construction may contain depleted uranium from past operations (DOE, 1996d). Some explosives tests will be conducted at other existing firing tables onsite as discussed in the 1992 EIS/EIR.

- In addition to reducing the routine use of lead in explosive shots (thereby reducing generation of hazardous and mixed waste), changes in Site 300 waste operations have included the use of a gravel washer to reduce LLW generation. After a shot involving depleted uranium, gravel on the firing tables in the vicinity of the shot is assumed to be contaminated and is removed as waste. In the past, all of this material was considered 
LLW, but the gravel is now washed to remove fines, and only the sludge and wastewater from this operation are disposed of as LLW. The reconditioned gravel is returned to the firing tables.

- As described in the 1992 EIS/EIR, construction of the Explosives Waste Storage Facility would permit segregated storage of various forms of explosives waste and would increase overall explosives storage capacity. Facility construction would involve the reassignment of several existing bunkers and the construction of a new Butler building.

- Segregation of debris, administrative controls, and material substitution resulted in a $19 \%$ decrease from 1993 levels in the amount of contaminated gravel generated during explosive testing at Site 300 in 1994. Further reductions were realized in 1995 with the initiation of gravel washing, as described above (LLNL, 1994a).

All of these waste management program and facility upgrades and LLNL operational changes have been accounted for in the total waste projections presented below. The projections are made on the basis of the following assumptions (LLNL, 1996b):

- LLNL achieves its waste minimization goals for routine waste (which it has to date).

- Nonroutine waste (waste not generated by routine operations) generation continues at a level consistent with the ratio of nonroutine waste to total waste generated in 1994.

- New projects generate waste (both routine and nonroutine) as described above.

\section{Radioactive Waste}

Changes in radioactive waste management at LLNL since certification of the 1992 EIS/EIR and those projected for the future are:

- Establishment of the LLW certification program,

- Initiation of AVLIS Pilot Operations, and

- $\quad$ Contained onsite storage of TRU waste pending shipment to the WIPP.

\section{Liquid Low-Level Radioactive Waste}

Liquid low-level radioactive waste is generated primarily by routine operations. Except in 1994, it has been generated in quantities at or above those projected in the 1992 EIS/EIR. Generation rates would be increased further by the IPD and Pilot Operations phases of AVLIS operations.

\section{Solid Low-Level Radioactive Waste}

Reduction of accumulated solid LLW at LLNL following approval of the certification program caused a spike in waste shipments (which were recorded as waste generation in the database) in 1994. A similar short-term increase is predicted to occur in 1996-1997 as a result of the planned excavation of soils at Site 300 in preparation for construction of the Contained Firing Facility. The long-term impact on solid low-level radioactive waste generation at LLNL (both sites) would be the 
initiation of the AVLIS Program. Waste generation in the isotope separation program would double by 1997 and double again by 1999 .

The waste projections are based on the assumption that LLNL will achieve a $50 \%$ reduction in lowlevel waste generation by 2000 from the 1993 baseline. Solid LLW generation is likely to continue to exceed the volume projected in the 1992 EIS/EIR because of new programs.

\section{Iransuranic and Transuranic-Mixed Waste}

LLNL no longer stores TRU waste at the Nevada Test Site to await shipment to Carlsbad, New Mexico, for disposal at the WIPP. Instead, TRU and TRU-mixed waste are stored onsite. These wastes routinely accumulate at a rate of approximately 100 55-gallon-drum-equivalents per year, well below $1992 \mathrm{EIS} / \mathrm{EIR}$ projections. Reductions reflect contract waste minimization requirements. Some of LLNL's TRU waste may soon be stored in Building 280 as contact-handled high-activity waste.

\section{Hazardous Waste}

Except for those changes previously discussed, all of which are documented in RCRA Part B permit applications, no substantial changes in the management of hazardous wastes have occurred since certification of the 1992 EIS/EIR.

The generation of hazardous waste liquids has declined in recent years as a result of waste minimization efforts, especially at paint spray booths. Spray booths are now fitted with units for separating paint solids so that large volumes of water can be recycled. All actuals and projections are well below the levels predicted in the 1992 EIS/EIR.

Generation of hazardous waste solids is affected by nonroutine waste generation, such as housekeeping activities, which caused a temporary increase in 1995. By 1998, however, waste minimization efforts are expected to reduce solid hazardous waste generation rates to within levels projected in the 1992 EIS/EIR.

\section{Low-Level Mixed Waste}

Management of low-level mixed waste has been charged with the initiation of efforts to reduce stored inventories and the general shift toward treatment, instead of storage of mixed waste (both onsite and offsite) in accordance with commitments identified in the draft LLNL Site Treatment Plan.

The generation of low-level mixed waste liquids is expected to remain well below levels projected in the $1992 \mathrm{EIS} / \mathrm{EIR}$. These reductions are attributable to waste minimization efforts. Also, although the relatively high levels of mixed waste liquid generated in the early 1990 s were considered routine waste because they came from routine operations, they were primarily attributable to one-time waste removal effort.

The generation of low-level mixed waste solids is expected to remain well below levels projected in the 1992 EIS/EIR. The projected reductions are attributable to waste minimization efforts. Although there is a recent trend toward increased generation, solid mixed waste is affected by nonroutine waste generation that is often not repeated, and routine solid mixed waste generation is actually decreasing. If excavation at Site $\mathbf{3 0 0}$ in preparation for the Contained Firing Facility 
yields increased quantities of mixed waste soil (as opposed to LLW, as predicted), such waste could be readily shipped to an approved disposal facility such as Envirocare, Utah, for disposal, and consequently would not exceed capacities of mixed waste storage.

\section{IMPACTS}

This section assesses the potential environmental impacts from changes that have occurred at both the Livermore site and Site 300 since 1992 and proposed changes that are likely to affect waste management by the year 2002 . It does not address the many beneficial impacts of recent program improvements in waste management at LLNL.

The only significant impact identified in the 1992 EIS/EIR was stated as follows: "Mixed waste generation may require onsite storage beyond storage limits prescribed by RCRA and could result in a need for additional storage capacity. This is a potentially significant and unavoidable impact."

The buildup of mixed waste onsite is not of concern and is no longer a significant, unavoidable impact of LLNL operations because the Federal Facility Compliance Act provided regulatory relief, offsite treatment and disposal options have become available, and the storage and treatment capabilities of LLNL would be expanded.

Impact: $\quad$ The generation of several different waste types is predicted to exceed the growth rate projected in the 1992 EIS/EIR. This impact is considered less tnan significant.

Despite significant successes in waste minimization at the LLNL Livermore site, the growth of certain programs would outpace reductions in generation of solid and liquid LLW in other areas. For example, the results of a reasonable worst-case analysis of the impact of AVLIS Pilot Operations would indicate that, in 1999 and beyond, Pilot Operations could increase the eight-year average generation rate of LLW solids by as much as $80 \%$.

However, the effect of this increase in LLW generation is considered less than significant. The solid waste originating at AVLIS is, and would continue to be, certified for transport and disposal at the Nevada Test Site, no solid waste treatment and associated emissions would occur, and onsite waste accumulation should not increase substantially.

\section{SUMMARY CONCLUSION}

The proposed project is consistent with the waste management analysis presented in the 1992 EIS/EIR and does not involve substantial changes in the project or in the circumstances surrounding the project. In addition, this analysis does not indicate that the project would result in one or more new or substantially more severe significant environmental impacts. There are no mitigation measures or alternatives previously found to be infeasible that would in fact be feasible, nor are there mitigation measures or alternatives that are considerably different from those analyzed in the 1992 EIS/EIR that would substantially reduce one or more significant impacts that have not been adopted. 


\title{
3.16 OCCUPATIONAL PROTECTION
}

\author{
Subsection: 4.16.1, Subsection: 5.1.14, Appendix: C
}

Standards of Significance: Page 5-171

\section{SETTING}

Some changes have occurred since certification of the $1992 \mathrm{EIS/EIR} \mathrm{in} \mathrm{the} \mathrm{regulatory} \mathrm{framework}$ applying to worker protection. However, these changes are minimal and, for the most part, the requirements remain the same. The annual occupational dose limit established by DOE is still 5 rem.

Discussions of the LLNL Livermore site and Site $\mathbf{3 0 0}$ have been combined in this subsection.

\section{LLNL LIVERMORE SITE AND SITE 300}

The LLNL occupational protection program applies to the workforce at both the LLNL Livermore site and Site 300.

\section{Internal Radiation Doses}

During 1995, the internal radiation dose to the maximally exposed individual in Building 331 was less than 0.01 rem and the collective dose from tritium was 0.01 person-rem (Shingleton, 1996), compared with doses of 0.16 rem and 0.5 person-rem in 1990. The reduction in dose is due primarily to the tritium facility's successful as low as reasonably achievable (ALARA) modemization program begun in 1992.

Based on past dose information, the annual radiation doses from current tritium handling activities at LLNL are projected to be approximately $0.00-0.05$ rem to the maximally exposed individual and the collective dose approximately $0.01-0.10$ person-rem over the next five years.

\section{External Radiation Doses}

During 1994, the external dose to the maximally exposed individual was 1.5 rem and the collective dose to the LLNL workforce, including activities at Site 300, from external exposure was 18.6 person-rem (Shingleton, 1996), compared with doses of 1.47 rem and 28.0 person-rem in 1990. This reduction in external radiation dose can be attributed to the reduction in the plutonium inventory in Building 332, the major source of external radiation exposure at LLNL. There was a small, temporary increase in external exposure attributable to the increased handling of plutonium during inventory reduction and packaging in preparation for offsite shipment.

Annual radiation doses to the LLNL workforce from external exposures are expected to be approximately 1-2 rem to the maximally exposed individual with collective doses on the order of 10-30 person-rem per year over the next five years, based on past dose information. 


\section{Total Radiation Dose from LLNL Operation}

During 1995, the total collective dose to all LLNL workers from both internal and external radiation exposure was 13 person-rem (Shingleton, 1996), compared with 28 person-rem in 1990.

The collective dose to the LLNL workforce from both external and internal exposure is projected to be approximately 10-30 person-rem per year over the next five years based on inspection of recent information provided by the LLNL Hazards Control Department (Shingleton, 1996).

\section{IMPACTS}

Impact: Decontamination and demolition of Building 222 may result in measurable radiation doses to workers directly involved in these activities. This impact is considered less than significant.

The levels of radiation dose would be maintained as low as reasonably achievable and would be well within the annual dose limits prescribed for DOE operations.

Impact: Pilot plant operations for enriching uranium could increase radiation doses to workers in the Separator Demonstration Facilities Complex. This impact is considered less than significant.

The radiation doses to workers at the Separator Demonstration Facilities Complex are well within the annual dose limits prescribed for DOE operation and use and are not significant contributors to the total collective radiation dose at LLNL.

\section{SUMMARY CONCLUSION}

The proposed project is consistent with the occupational protection analysis presented in the 1992 EIS/EIR and does not involve substantial changes in the project or in the circumstances surrounding the project. In addition, this analysis does not indicate that the project would result in one or more new or substantially more severe significant environmental impacts. There are no mitigation measures or alternatives previously found to be infeasible that would in fact be feasible, nor are there mitigation measures or alternatives that are considerably different from those analyzed in the 1992 EIS/EIR that would substantially reduce one or more significant impacts that have not been adopted. 


\title{
3.17 SITE CONTAMINATION AND REMEDIATION
}

\author{
Subsection: 4.17, Subsection: 4.19, Subsection: 5.1 .15
}

Standards of Significance: Page 5-181

\section{SETTING}

\section{LLNL LIVERMORE SITE}

The 1992 EIS/EIR presented an overview of historic operations that contributed to site contamination and the need for remediation in Subsection 4.17, "Site Contamination and Remediation."

Full-scale implementation of ground water remediation was predicted in the 1992 EIS/EIR to be phased in over a period of two to three years. Seven permanent ground water treatment facilities (TF) TFA, TFB, TFC, TFD, TFE, TFF, and TFG, were identified at that time. By June 1996, five of the seven (TFA, TFB, TFC, TFD, and TFF) were constructed and operating. In addition, the vapor extraction facility in Building $\mathbf{5 1 8}$ was also completed.

The TFE and TFG have been proposed to be portable, rather than permanent as described in the 1992 EIS/EIR, primarily because of funding limits and efforts to optimize the extraction well system. Although full-scale implementation or remediation has been slowed, no deadlines specified in the 1992 EIS Record of Decision were missed.

Design of portable TFE is currently underway, and Remedial Design Report No. 5 for TFG (LLNL, 1995a) was completed in March 1995, in accordance with the revised project schedule presented in the Remedial Action Implementation Plan (LLNL, 1993b).

In early 1993, TFF (in the Gasoline Spill Area) was used for the Dynamic Underground Stripping Demonstration Project. Electrical heating and steam injection were studied as enhancements to the pump-and-treat method of ground water remediation and to accelerate contaminant removal by vapor extraction above that achieved at ambient temperatures. Ground water extraction at TFF ceased on April 18, 1995, for a 6-month biodegradation study, and restarted again on October 17 , 1995. With regulatory concurrence, extraction and treatment of the residual dissolved fuel hydrocarbons in two hydrostratigraphic units have been discontinued in favor of passive bioremediation. In 1996, regulators ruled that no further remediation was required for the vadose zone. A portable treatment unit will be installed in 1997 to remediate volatile organic compounds in a deeper aquifer (LLNL, 1996d).

The studies of steam injection and bioremediation at TFF have served as precursors to a larger scale application of innovative technology intended to accelerate cleanup at the LLNL Livermore site (see discussion of the Accelerated Cleanup Initiative pilot test below).

A total of 18 sites requiring extraction (i.e., extraction wells or well clusters feeding the treatment facilities) were selected in the Preliminary Remedial Action Plan and discussed in the 1992 
EIS/EIR. Since then, numerical simulations of contaminant transport (using the computer model CFEST and a cleanup goal of 5 parts per billion [ppb] of total volatile organic compounds achieved in 50 years) indicated a need to add six extraction sites to the system. Three of these are onsite and three are offsite (just west of Vasco Road). These additional extraction sites are designed to prevent potential southerly plume migration in response to depression of the water table during agricultural pumping south of East Avenue (LLNL, 1993b).

The 1992 EIS/EIR discussed plans for vadose zone remediation using vapor extraction in two areas: the Gasoline Spill Area and the Building 518 Area. Plans for vadose zone vapor treatment originally involved piping vapors from Building 518 to TFF (the Gasoline Spill Area) for treatment. Instead, Building 518, located in the southeast quadrant of the LLNL Livermore site near East Avenue, treats soil vapor collected from several extraction wells using granulated activated carbon canisters (which are more cost effective than the originally planned catalytic oxidation process) to remove volatile organic compounds. Operations at Treatment Facility 518 began in September 1995.

The East Taxi Strip-Building 5475 Area was added as a vadose zone contamination source area after the $1992 \mathrm{EIS/EIR}$ was published. Cleanup in this area is complicated by the intermixing of volatile organic compounds and tritium in a plume that the Laboratory does not wish to bring to the surface for treatment because of the perceived potential for increased occupational exposure and offsite dose. A new facility designed to treat the contamination in situ, without producing a mixed waste, is being evaluated.

The 1992 EIS/EIR predicted a 50-year duration for ground water remediation (to $5 \mathrm{ppb}$ total volatile organic compounds) at the LLNL Livermore site. The life-cycle cost of this endeavor was estimated to be at least $\$ 100$ million. In an effort to reduce the life-cycle cost by accelerating cleanup, LLNL has proposed implementing an Accelerated Cleanup Initiative beginning in fiscal year 1997. The initiative would demonstrate technologies to remediate source regions of contaminated ground water rapidly while preventing further plume dispersal. Hydrous pyrolysis through steam injection would be used to oxidize organic contaminants in the source area. Steam injection would displace contaminated water in the aquifer and create a high-temperature treatment zone below the surface. Once injection is stopped, contaminated water would return to the treatment zone, where it would be heated by the hot geologic materials. According to laboratory tests, this heating would cause contaminants in the water to oxidize, resulting in carbon dioxide, hydrogen ion, and chloride ion (LLNL, 1996a).

In-situ microbial filters would be established downgradient of the steam injection to biodegrade the unremediated portions of the plume. The biofilters would metabolize contaminants as water passes through. The Accelerated Cleanup Initiative pilot test is proposed to begin in 1997 near the LLNL Livermore site helipad in an area with $500 \mathrm{ppb}$ total volatile organic compounds. The pilot study is anticipated to be completed in 1999, and application may continue in other source areas depending on the performance of the pilot project (LLNL, 1996a).

For this pilot test, steam would be produced using one or more natural gas-fired boilers requiring an energy output of approximately 50 million BTUs. Use of the system at additional source areas is not expected to involve scale-up of the pilot system. (See Subsection 3.9, "Air Quality," for a discussion of potential air quality impacts and Subsection 3.13, "Utilities and Energy," for discussion of potential utilities and energy impacts.) 
In June 1992, a Federal Facility Agreement was signed that governs activities at the site related to the Comprehensive Environmental Response, Compensation and Liability Act of 1980 (CERCLA). The latest delineation of study areas and constituents of concern is shown in Figure 3.17-1 (LLNL, 1996d). Since certification of the 1992 EIS/EIR, these areas have been reorganized as follows:

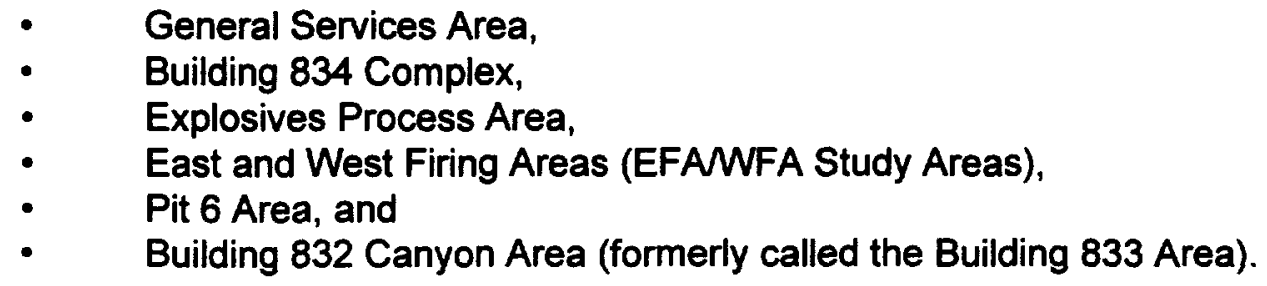

In 1991, the regulatory agencies requested that Site 300 prepare a site-wide remedial investigation report to replace the area-specific, individual draft remedial investigation reports that had been submitted previously. The final Site-Wide Remedial Investigation Report (LLNL, 1994b) was submitted to the U.S. Environmental Protection Agency (EPA), the Central Valley Regional Water Quality Control Board (CVRWQCB), and the California Department of Toxic Substances Control (DTSC) in 1994. The final report is a compilation of all ground water and soil investigation information and contains an assessment of potential human health and ecological hazards (LLNL, 1996d).

LLNL has recently initiated negotiations with the EPA, CVRWQCB, and DTSC to develop and implement an accelerated cleanup process for Site 300 . Following are some recent changes and issues still being discussed.

- Site 300 could continue to conduct portions of the cleanup program as a series of CERCLA removal actions instead of as a full-blown remedial action program. This process, called "CERCLA re-engineering," reduces the number of documents necessary to achieve cleanup.

- Maximum contaminant levels have replaced background concentrations as cleanup goals for ground water (which is consistent with cleanup goals at the LLNL Livermore site).

- Innovative technologies similar to the Accelerated Cleanup Initiative pilot test at the LLNL Livermore site could be implemented to accelerate soil and ground water cleanup.

To prevent additional migration of the trichloroethylene (TCE) plume in the Building 834 complex, Site 300 has proposed diversion of run-on water to Elk Ravine, which would prevent ground water recharge in the area of the existing plume. Modifications to the Building 834 Complex will include:

- $\quad$ Enhancement of pavement, curbs, and drainage ditches;

- Addition of asphalt, concrete, or vegetative mats to control erosion and infiltration on exposed areas in the complex;

- Installation of a siltation box; 


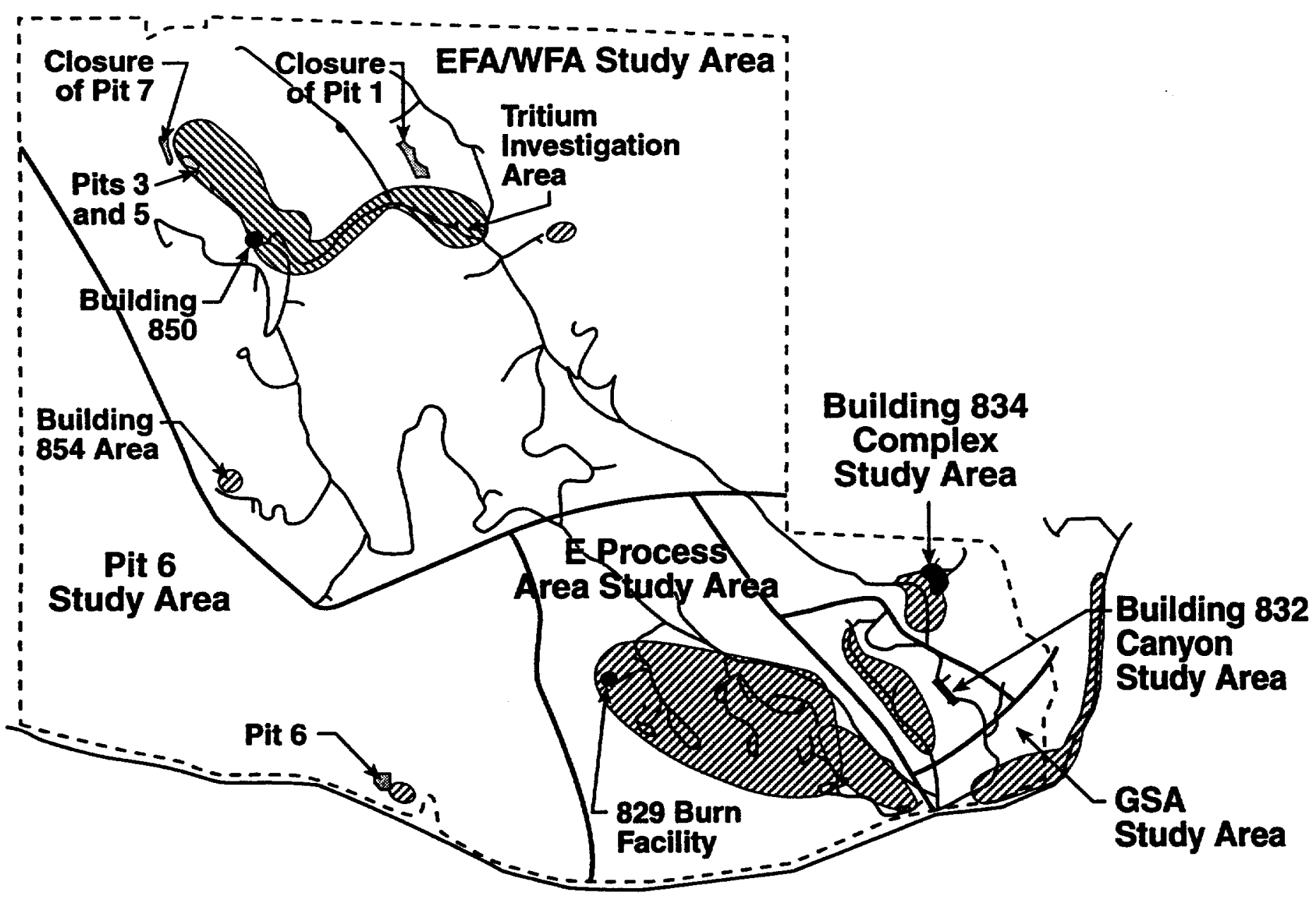

LEGEND

- - . SITE 300 PERIMETER

- STUDY AREA BOUNDARY

CI TRICHLOROETHYLENE (TCE) INVESTIGATION AREAS

TAITIUM INVESTIGATION AREA

LANDFILL

EFAWFA EAST FIRING AREAWEST FIRING AREA

E Process Area EXPLOSIVES PROCESS AREA

GSA GENERAL SERVICES AREA

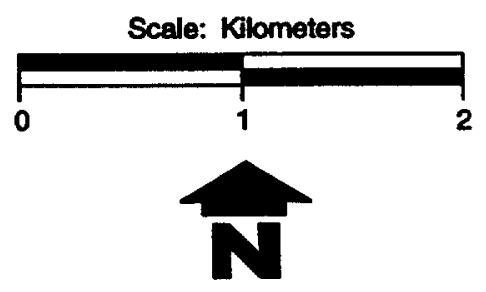

Figure 3.17-1. Environmental Restoration Study Areas and Activities at Site $\mathbf{3 0 0}$ 
- Installation of approximately 1730 feet of 15-inch-diameter culvert to carry stormwater to a deep ravine to the east (Elk Ravine); and

- Installation of an energy dissipator at the culvert outfall in Elk Ravine.

In 1994, additional investigations were conducted in the Explosive Process Area and the full extent of contamination defined. A Draft Evaluation of Remedial Alternatives Report for the Building 815 Operable Unit (LLNL, 1995a) was submitted to regulatory agencies in December 1995. Recent data indicate that migration of explosives and volatile organic compounds in this area is being attenuated by natural processes (e.g., adsorption, decomposition, and removal of hydraulic head); consequently, remediation activities have been suspended until further well installation, material sampling and analysis, and modeling have been completed. In addition, 25-30 drums will be removed from the Building 823 area in fiscal year 1996.

The 1992 EIS/EIR reported tritium and TCE contamination in the East and West Firing Areas. At the Pit 7 Complex in the West Firing Area, several wells have since yielded uranium concentrations in ground water (with a depleted uranium isotopic signature) that exceed maximum contaminant levels. Likewise, several wells in the nearby Building 850 Area have shown depleted uranium concentrations above background levels, which are associated with past disposal of firing table debris. Additional fieldwork was conducted in 1995 to define the extent of uranium, and determine the presence of polychlorinated biphenyls (PCBs), dioxins and furans, and volatile organic compounds in soil and ground water in these two areas. Also, three small depleted uranium plumes were identified emanating from Pits 5 and 7 and the Building 850 firing table and were discussed in an addendum to the Site-Wide Remedial Investigation Report (LLNL, 1996b).

Treatment technologies for tritium-bearing ground water were evaluated in 1995. Any action implemented as a result of this evaluation would likely include emplacement of impermeable barriers or subsurface drains to prevent infiltration of precipitation and subsequent contaminant migration. The preferred alternative for tritium remediation is to allow for radioactive decay in place (tritium has a half-life of only 12.3 years); ground water modeling indicates that the tritium plumes would decay to below maximum contaminant levels by the time they reach the property boundary.

\section{IMPACTS}

Impact: No impact on site contamination and remediation activities would occur.

No evidence has been identified indicating that the proposed project would result in disruption of site contamination remediation activities at LLNL. Remediation activities are anticipated to remain unaffected by the proposed project. 


\section{SUMMARY CONCLUSION}

The proposed project is consistent with the site contamination and remediation analysis presented in the 1992 EIS/EIR and does not involve substantial changes in the project or in the circumstances surrounding the project. In addition, this analysis does not indicate that the project would result in one or more new or substantially more severe significant environmental impacts. There are no mitigation measures or alternatives previously found to be infeasible that would in fact be feasible, nor are there mitigation measures or alternatives that are considerably different from those analyzed in the 1992 EIS/EIR that would substantially reduce one or more significant impacts that have not been adopted. 


\subsection{ENVIRONMENTAL COMPLIANCE AND INADVERTENT RELEASES}

Subsection: 4.18

Standards of Significance: Not applicable

\section{SETTING}

Discussions of the LLNL Livermore site and Site 300 have been combined in this subsection.

\section{LLNL LIVERMORE SITE AND SITE 300}

It is the policy of LLNL to comply with applicable federal, state, and local regulations, including requirements regarding environmental restoration, waste management, air and water quality management, tank management, materials management, environmental quality and resource protection, worker safety, and community right-to-know legislation. Detailed discussions of environmental compliance requirements, activities, and concerns are provided in the LLNL Annual Environmental Report (LLNL, 1996d; LLNL, 1995b; LLNL, 1995c; LLNL, 1994a; LLNL, 1993a).

No emergency occurrences have taken place at LLNL since certification of the 1992 EIS/EIR. LLNL had one unusual and 14 off-normal occurrences in 1993, three unusual and 21 off-normal occurrences in 1994, two unusual occurrences and 12 off-normal occurrences in 1995, and five offnormal occurrences in 1996 (as of June 30). Tables 3.18-1 and 3.18-2 summarize each of the unusual occurrences and the corrective actions taken; three of these occurred at the LLNL Livermore site and three at Site 300 . None of the incidents caused any adverse impacts on human health or the environment (LLNL, 1996d; LLNL, 1995b; LLNL, 1994a; Mancieri, 1996).

In addition to the audits conducted by regulatory agencies, LLNL also has its own internal programs to establish, verify, document, and report regulatory compliance, public and worker safety, and environmental protection with regard to ongoing operations. Reports and notices of violations from regulatory agencies that result from facility notifications or inspections, as well as other regulatory oversight activities, are automatically considered unusual occurrences. Although, by definition, future "inadvertent" releases cannot be anticipated, the number of occurrences at LLNL has decreased since 1994. 
Table 3.18-1. Summary of Unusual Environmental Occurrences at LLNL Livermore Site since 1992

\begin{tabular}{|c|l|c||}
\hline Date & \multicolumn{1}{|c|}{ Unusual Occurrence and Corrective Action } \\
\hline $3 / 30 / 93$ & $\begin{array}{l}\text { Approximately 11,400 liters of dishwashing wastewater discharged to soil in the } \\
\text { crawl space beneath the Central Cafeteria as a result of a failed coupling in a } \\
\text { sanitary sewage line. Sinks and dishwashers discharging through the line were } \\
\text { immediately taken out of use. Standing wastewater was pumped into the sanitary } \\
\text { sewer, the crawl space was ventilated, and affected soil was sprayed with } \\
\text { disinfectant. The coupling was repaired before sinks and dishwashers were } \\
\text { returned to service. }\end{array}$ \\
\hline $6 / 22 / 94$ & $\begin{array}{l}\text { A 20-centimeter water line was ruptured by a subcontractor during an excavation } \\
\text { for the Building 132 South Road project, releasing an estimated 170,000 liters of } \\
\text { water. By agreement, the San Francisco Bay Regional Water Quality Control } \\
\text { Board was informed because the release had the potential to affect ground water. } \\
\text { The ruptured water line was repaired. }\end{array}$ \\
\hline $8 / 7 / 95$ & $\begin{array}{l}\text { Analysis of 14 soil samples associated with } 2 \text { underground storage tanks that } \\
\text { were undergoing closure activities at the LLNL Livermore site indicated the } \\
\text { presence of gross alpha, gross beta, and tritium above the detection limits. As } \\
\text { required, an Unauthorized Release Contamination Site Report was prepared and } \\
\text { sent to the Alameda County Health Service Agency within } 5 \text { days. Because the } \\
\text { report did not arrive in the agency's offices within the 5-day window, however, the } \\
\text { agency issued a notice of violation. LLNL will make every effort to ensure that } \\
\text { future notifications and reports are received by the appropriate regulatory } \\
\text { agencies in a timely fashion. This incident was initially categorized as an off- } \\
\text { normal occurrence but was upgraded to an unusual occurrence because of the } \\
\text { notice of violation. }\end{array}$ \\
\hline
\end{tabular}

Sources: LLNL, 1996d; LLNL, 1995b; LLNL, 1994a. 
Table 3.18-2. Summary of Unusual Environmental Occurrences at Site 300 since 1992

\begin{tabular}{|c|l||}
\hline Date & \multicolumn{1}{c|}{ Unusual Occurrence and Corrective Action } \\
\hline \hline $1 / 18 / 94$ & $\begin{array}{l}\text { LLNL received a Report of Violation from DTSC in association with an inspection } \\
\text { at Site 300. The inspection noted "Inadequate/Lack Eyewash and Safety } \\
\text { Shower" at Building 805 and inadequate identification of wastes on a hazardous } \\
\text { waste label at Building 879. The operation requiring an eyewash and safety } \\
\text { shower was relocated to another facility with appropriate support systems. The } \\
\text { hazardous waste label was completed as required. }\end{array}$ \\
\hline $8 / 12 / 94$ & $\begin{array}{l}\text { Analysis of Building } 865 \text { cooling tower sludge at Site 300 identified a zinc } \\
\text { concentration of 26,000 parts per million, which exceeded the threshold } \\
\text { concentration limit of 5,000 parts per million. The CVRWQCB was notified of the } \\
\text { finding; DTSC was later notified of the finding after the material was categorized } \\
\text { as hazardous waste. Sludge management practices were modified from surface } \\
\text { deposition to storage in containers for disposal. This occurrence was originally } \\
\text { categorized as an off-normal occurrence but was later upgraded to an unusual } \\
\text { occurrence because DTSC was not immediately notified of the finding. }\end{array}$ \\
\hline 2/10/95 & $\begin{array}{l}\text { An accidental discharge of 1,2-Dichloroethane into the Site 300 Class II explosive } \\
\text { wastewater surface impoundment was discovered during the review of old } \\
\text { analytical reports. The National Response Center, California Office of } \\
\text { Emergency Services, San Joaquin County Public Health Services Office of } \\
\text { Emergency Services, CVRWQCB, and DTSC were notified of the discharge. On } \\
\text { April 20, the CVRWQCB issued a notice of violation. To minimize the potential } \\
\text { for future discharges of waste inappropriate for the surface impoundments, all } \\
\text { influent waste streams are now held pending evaluation of analytical data. }\end{array}$ \\
\hline
\end{tabular}

Sources: Knight, 1996; LLNL, 1996d; LLNL, 1995b; LLNL, 1994a.

\section{IMPACTS}

Impact: No impact to environmental compliance activities and emergency response systems.

No known or potential adverse environmental impacts have been associated with existing or proposed LLNL environmental compliance activities or past inadvertent releases. As demonstrated by past performance, existing and proposed LLNL environmental compliance and emergency response systems have been sufficient to manage existing compliance activities and inadvertent environmental releases. Proposed LLNL environmental compliance and emergency response systems are being developed to enhance environmental compliance efforts. No changes to environmental compliance or inadvertent release management systems have been identified. 


\section{SUMMARY CONCLUSION}

The proposed project is consistent with the environmental compliance and inadvertent releases analysis presented in the 1992 EIS/EIR and does not involve substantial changes in the project or in the circumstances surrounding the project. In addition, this analysis does not indicate that the project would result in one or more new or substantially more severe significant environmental impacts. There are no mitigation measures or alternatives previously found to be infeasible that would in fact be feasible, nor are there mitigation measures or alternatives that are considerably different from those analyzed in the 1992 EIS/EIR that would substantially reduce one or more significant impacts that have not been adopted. 


\section{SECTION 4.0 CUMULATIVE IMPACTS}

The proposed project would not result in any new cumulative impacts or increase the severity of the cumulative impacts identified in the 1992 EIS/EIR. 


\section{SECTION 5.0 \\ IRREVERSIBLE AND IRRETRIEVABLE COMMITMENT OF RESOURCES}

The significant impact of irreversibly and irretrievably committed resources has not changed since certification of the 1992 EIS/EIR and is not anticipated to change through 2002. Consumption of water and electricity remains below the growth rate projected in the 1992 EIS/EIR. Natural gas usage has increased, but this increase is partially offset by a reduction in the use of electricity. Consumption of these resources through 2002 is projected to remain at or below the growth rate projected in the 1992 EIS/EIR. Resource use is discussed in Section 3.0, "Environmental Setting and Impact Analysis," of this EIR addendum. 


\section{SECTION 6.0 GROWTH-INDUCING IMPACTS}

No significant growth-inducing changes have occurred as a result of LLNL operations since certification of the 1992 EIS/EIR. Services, roads, and utilities have not been extended into unserved areas. Physical or policy obstacles to development have not been removed, and no substantial alteration of overall development patterns and plans for LLNL occurred. No actions by LLNL have occurred or are projected to occur that could stimulate economic or population growth or the construction of additional housing in the surrounding environment. Declines in Laboratory workforce have resulted in decreases in housing demand and student enrollment related to LLNL. Air quality impacts and traffic impacts are also less than anticipated due to the reduction in Laboratory workforce. 


\section{SECTION 7.0 SUMMARY AND DETERMINATION}

This addendum analyzes the environmental impacts associated with the proposed extension of the contract between DOE and UC for operation and management of LLNL. The contract extension period (1997-2002) is within the time frame addressed in the 1992 EIS/EIR, which documented impacts of continued operation and management until 2002. UC adopted findings and a mitigation monitoring plan to implement the mitigation measures recommended in the $1992 \mathrm{EIS/EIR.}$

This addendum concludes that the proposed project would not result in:

- Substantial changes in the project that would require major revisions of the 1992 EIS/EIR due to the involvement of new significant effects or a substantial increase in the severity of previously identified significant effects;

- Substantial changes with respect to the circumstances under which the project is undertaken, which would require major revisions of the previous EIR due to the involvement of new significant environmental effects or a substantial increase in the severity of previously identified significant effects; or

- New information of substantial importance that was not known or could not have been known with the exercise of reasonable diligence when the 1992 EIS/EIR was certified and that shows any of the following:

- $\quad$ The project would have one or more significant effects not discussed in the 1992 EIS/EIR;

- $\quad$ Significant effects examined previously would be substantially more severe than shown in the 1992 EIS/EIR;

- $\quad$ Mitigation measures or alternatives previously found not to be feasible would in fact be feasible, and would substantially reduce one or more significant effects of the project, but the project proponents decline to adopt the mitigation measure or alternative; or

- $\quad$ Mitigation measures or alternatives that are considerably different from those analyzed in the 1992 EIS/EIR would substantially reduce one or more significant effects on the environment, but the project proponents decline to adopt the mitigation measure or alternative (Pub. Res. Code 21166; CCR 15162, 15163).

In summary, there have been no changes in circumstances or in LLNL operations and no new information of substantial importance that would involve substantial impacts or a substantial increase in the severity of previously identified significant impacts from the implementation of the proposed project.

On the basis of substantial evidence in light of the whole record, the UC Board of Regents has determined that this addendum to the 1992 EIS/EIR fully and adequately analyzes the environmental impacts associated with the proposed project and provides the appropriate level of 
environmental review to support contract extension with DOE. This addendum has been prepared in compliance with applicable provisions of CEQA, as amended; the State CEQA Guidelines, and UC's CEQA guidelines. 


\section{SECTION 8.0 SUMMARY AND DETERMINATION}

This addendum analyzes the environmental impacts associated with the proposed extension of the contract between DOE and UC for operation and management of LLNL. The contract extension period (1997-2002) is within the time frame addressed in the 1992 EIS/EIR, which documented impacts of continued operation and management until 2002. UC adopted findings and a mitigation monitoring plan to implement the mitigation measures recommended in the 1992 EIS/EIR.

This addendum concludes that the proposed project would not result in:

- $\quad$ Substantial changes in the project that would require major revisions of the 1992 EIS/EIR due to the involvement of new significant effects or a substantial increase in the severity of previously identified significant effects;

- Substantial changes with respect to the circumstances under which the project is undertaken, which would require major revisions of the previous EIR due to the involvement of new significant environmental effects or a substantial increase in the severity of previously identified significant effects; or

- New information of substantial importance that was not known or could not have been known with the exercise of reasonable diligence when the 1992 EIS/EIR was certified and that shows any of the following:

- $\quad$ The project would have one or more significant effects not discussed in the 1992 EIS/EIR;

- $\quad$ Significant effects examined previously would be substantially more severe than shown in the 1992 EISIEIR;

- $\quad$ Mitigation measures or altematives previously found not to be feasible would in fact be feasible, and would substantially reduce one or more significant effects of the project, but the project proponents decline to adopt the mitigation measure or alternative; or

- Mitigation measures or alternatives that are considerably different from those analyzed in the 1992 EIS/EIR would substantially reduce one or more significant effects on the environment, but the project proponents decline to adopt the mitigation measure or alternative (Pub. Res. Code 21166; CCR 15162, 15163).

In summary, there have been no changes in circumstances or in LLNL operations and no new information of substantial importance that would involve substantial impacts or a substantial increase in the severity of previously identified significant impacts from the implementation of the proposed project.

On the basis of substantial evidence in light of the whole record, the UC Board of Regents has determined that this addendum to the 1992 EIS/EIR fully and adequately analyzes the environmental impacts associated with the proposed project and provides the appropriate level of 
environmental review to support contract extension with DOE. This addendum has been prepared in compliance with applicable provisions of CEQA, as amended; the State CEQA Guidelines, and UC's CEQA guidelines. 


\section{LIST OF PREPARERS}

The overall effort for this EIR addendum was directed by LLNL through Judith C. Steenhoven and her deputy, Charles W. Meier. Assistance for the preparation of this document was provided by LLNL technical advisors on the LLNL Steering Committee and by Roy F. Weston, Inc. (W) under the direction of William N. Taber and his deputy, Francine Demos-Petropoulos (Jones \& Stokes Associates, Inc.). The WESTON Team included subcontractor Jones \& Stokes Associates (JSA).

Those authors who were principals in preparing this EIR addendum are identified below. Rebecca de Neri Zagal (W) served as lead author for the addendum.

Section

Section 1.0 Introduction

Section 2.0 Project Description

Section 3.0 Environmental Setting and Impact Analysis

3.1 Land Use and Applicable Plans

3.2 Socioeconomic Characteristics

3.3 Community Services

3.4 Prehistoric and Historic Cultural Resources

3.5 Aesthetics and Science Resources

3.6 Meteorology

3.7 Geology

3.8 Ecology

3.9 Air Quality

3.10 Water

3.11 Noise

3.12 Traffic and Transportation

3.13 Utilities and Energy

3.14 Materials Management

3.15 Waste Management

3.16 Occupational Protection

3.17 Site Contamination and Remediation

3.18 Environmental Compliance and Inadvertent Releases

Section 4.0 Cumulative Impacts

Section 5.0 Irreversible and Irretrievable Commitment of Resources

Section 6.0 Growth-Inducing Impacts

Section 7.0 Significant and Unavoidable Adverse

Environmental Impacts

Section 8.0 Summary and Determination

\section{Principal}

F. Demos-Petropoulos (JSA)

W. Taber $(W)$

C. Roner (W); D. Wolf (W)
K. Chew (JSA)

M. Langley (JSA)

M. Langley (JSA)

D. McGowan (JSA)

K. Chew (JSA)

M. Langley (JSA)

M. Langley (JSA)

S. Bechta (JSA); R. Preston (JSA)

W. Shijo (JSA); T. Rimpo (JSA)

M. Langley (JSA)

D. Buehler (JSA)

D. Buehler (JSA)

C. Roner (W); D. Wolf $(W)$

L. Stuhl $(W)$

J. Krueger $(W)$

D. Jacobs $(W)$

J. Krueger (W)

J. Krueger (W)

W. Taber $(W)$

R. de Neri Zagal (W)

R. de Neri Zagal (W)

R. de Neri Zagal (W)

R. de Neri Zagal (W) 
The management and technical staff were highly supported by the following administrative and editorial support throughout the project.

$\begin{array}{lll}\text { Patti Zazueta } & \text { Administrative Assistant } & \text { LLNL } \\ \text { Ellie D'Innocente } & \text { Administrative Assistant } & \text { W } \\ \text { Victoria Axiaq } & \text { Lead Editor } & \text { JSA } \\ \text { Debra Lilly } & \text { Editor } & \text { JSA } \\ \text { Jim Merk } & \text { Editor } & \text { JSA }\end{array}$

Jones \& Stokes Associates also provided additional technical guidance in the persons of Michael Rushton (principal-in-charge) and Al Herson (CEQA advisor). 


\section{ABBREVIATIONS AND ACRONYMS}

AVLIS

BAAQMD

BART

BTU

CCR

CEQA

CERCLA

CESA

CFR

Co

CVRWQCB

DOE

DOE/NV

DOE/OAK

DTSC

DWTF

EIR

EIS

EFAWFA

EPA

ESA

FITS

FR

g

A-1
Atomic Vapor Laser Isotope Separation

Bay Area Air Quality Management District

Bay Area Rapid Transit

British thermal unit

California Code of Regulations

California Environmental Quality Act

Comprehensive Environmental Response, Compensation and Liability Act of 1980

California Endangered Species Act

Code of Federal Regulations

Carbon monoxide

Central Valley Regional Water Quality Control Board

U.S. Department of Energy

U.S. Department of Energy Nevada Operations Office

U.S. Department of Energy Oakland Operations Office

Department of Toxic Substances Control

Decontamination and Waste Treatment Facility

Environmental Impact Report

Environmental Impact Statement

East firing area/west firing area

U.S. Environmental Protection Agency

Endangered Species Act

Facility Information Tracking System

Federal Register

Gram 


\section{ABBREVIATIONS AND ACRONYMS}

(continued)

IPD

Integrated Process Demonstration

kg

Kilogram

LLNL

Lawrence Livermore National Laboratory

LLW

Low-level waste

NEPA

National Environmental Policy Act

NIF

National Ignition Facility

$\mathrm{NO}_{\mathrm{X}}$

Nitrogen oxides

PCBs

Polychlorinated biphenyls

PEIS

Programmatic environmental impact statement

PEV

Performance evaluation and verification

$\mathrm{PM}_{10}$

Particulate matter less than or equal to 10 microns in diameter

ppb

Parts per billion

Pub. Res. Code

Public Resources Code

RCRA

Resource Conservation and Recovery Act

SARA

Superfund Amendments and Reauthorization Act

SHARP

Super High Altitude Research Project

SJVUAPCD

San Joaquin Valley Unified Air Pollution Control District

TCE

Trichloroethylene

TF

Treatment facility

TRU

Transuranic (waste)

UC

University of California

USC

United States Code

USEC

United States Enrichment Corporation

WIPP

Waste Isolation Pilot Plant 


\section{ABBREVIATIONS AND ACRONYMS}

(continued) 


\section{GLOSSARY}

Accelerator

Activity

Acute

Administrative limit

Aquifer

Archaeological resources

As low as reasonably

achievable (ALARA)

Beryllium

Biodegradation

Biofilter

Bioremediation

Candidate species

Carcinogenic

Catalytic oxidation

Conservative

Controlled material

Cultural resources (historic)
An apparatus for imparting high velocities to charged particles.

The number of nuclear transformations occurring in a given quantity of material per unit time.

A dose or toxicity that occurs in a short time.

A limit imposed administratively on the quantity of a radionuclide permitted in a building or part of a building.

A water-bearing stratum of permeable rock or sediments capable of producing economically significant quantities of water to wells and springs.

See Cultural resources (prehistoric).

A philosophy of protection that controls and maintains exposures to individuals and to the workforce and general public as low as technically and economically feasible below the established limits.

A toxic metal of atomic number 4 . Natural beryllium consists entirely of beryllium-9.

The metabolization of environmental contaminants by microorganisms.

A mass of microorganisms that serves to remove and destroy contaminants from water flowing through the mass.

Cleanup of contaminated ground water by microorganisms.

Species being reviewed by the U.S. Fish and Wildlife Service for possible listing as endangered or threatened, but for which substantial biological information to support a listing is lacking.

A substance that directly or indirectly causes cancer.

Volatile compounds in a ground water treatment system are destroyed by oxidation mediated by a material such as a noble metal that increases the rate of oxidation but emerges from the process unchanged.

Assuming consequences that are greater than the most likely consequences; using assumptions that tend to overestimate consequences, that err on the side of safety.

Materials designated by DOE or LLNL for special control because they are classified, hazardous, of national interest, or of high monetary value.

Material remains, such as trash dumps and architectural features, including structures, foundations, basements, and wells; any other physical alteration of the landscape, such as ponds, roads, landscaping, and fences. 


\section{GLOSSARY}

(continued)

Cultural resources

(prehistoric)

Cumulative impacts

Decommissioning

Decontamination

Department of Toxic

Substances Control (DTSC)

Depleted uranium

Detection limit

Dose

Effective dose equivalent
Any material remains of items used or modified by people, such as artifacts of stone, bone, shellfish, or wood. Animal bone, fish remains, bird bone, or shellfish remains used for food are included. Physical alteration of the landscape, such as hunting blinds, remains of structures, excavated house pits, and caches of artifacts or concentrations of stones (such as cooking stones) are also prehistoric cultural resources.

As defined in CEQA, ". . . two or more individual effects which, when considered together, are considerable or which compound or increase other environmental impacts.

"(a) The individual effects may be changes resulting from a single project or a number of separate projects.

"(b) The cumulative impact from several projects is the change in the environment which results from the incremental impact of the project when added to other closely related past, present, and reasonably foreseeable probable future projects. Cumulative impacts can result from individually minor but collectively significant projects taking place over a period of time."

The process of removing a facility from operation. The facility is then mothballed, entombed, or decontaminated, after which it is dismantled or converted to another use.

The removal of unwanted material, especially radioactive material, from the surface or from within another material.

The state agency responsible for administering the California Hazardous Waste Control Law and implementing regulations within the California Environmental Protection Agency.

Uranium from which most of the uranium-235 isotope has been removed.

The minimum concentration at which environmental contaminants can be reliably detected given the limitations of analytical equipment.

A general term denoting the quantity of radiation or energy absorbed. For special purposes, it must be qualified appropriately.

The dose equivalent from irradiation of an organ or part of the whole body that bears the same risk of cancer as uniform irradiation of the whole body; the sum, over specified tissues, of the products of the dose equivalent in a tissue and the weighting factor for that tissue. The effective dose equivalent is expressed in units of rem (or sievert). 


\section{GLOSSARY}

(continued)

Emergency occurrence

Endangered species

Enriched uranium

Environmental compliance

Explosives

Explosive shots

External exposure

Fines

Firing table

General plan

Gross alpha

Gross beta

Half-life, radioactive

Hazardous waste

High-activity waste
An emergency event or condition requiring increased alert status for on-site personnel and, in specified cases, for off-site authorities. Identified in the DOE 5500 series of Orders as the most serious occurrence.

Species of plants and animals that are threatened with either extinction or serious depletion in their range and that are formally listed as such by the U.S. Fish and Wildlife Service.

Uranium enriched in the fissile nuclide uranium-235.

Meeting applicable federal, state, and local environmental regulations.

Chemically energetic materials with the potential to react explosively (nuclear explosives are not included).

The intentional detonation of explosive materials during tests or experiments.

Radiation exposure from sources outside the body, such as cloud passage, material deposited on the ground, and nearby surfaces.

Small particles of materials that are dislodged from a larger mass of the material during manufacturing or machining processes.

A table placed on a gravel or concrete pad on which experiments with explosives are set up and fired. The term also refers to the pad on which the test is conducted.

A compendium of city or county policies regarding long-term development in the form of maps and accompanying text. The general plan is a legal document required of each local agency by California Government Code Section 65301 and adopted by the city council or board of supervisors. The general plan may also be called a "city plan," "comprehensive plan," or "master plan."

The concentration of all alpha-emitting radionuclides in a sample. The concentration of all beta-emitting radionuclides in a sample.

Time required for a radioactive substance to lose $50 \%$ of its activity by decay.

Any solid, semisolid, liquid, or gaseous waste that is ignitable, corrosive, toxic, or reactive as defined by the Resource Conservation and Recovery Act and identified or listed in 40 CFR 261 and 22 CCR 66261.

Waste with sufficient radioactivity to require the use of remote handling systems during routine operations to protect workers from unwarranted exposure. 
High-temperature treatment zone

Historic resources

Hot geologic materials

Hydraulic head

Hydrostratigraphic units

Impact

Impermeable barrier

Inadvertent release

Influent waste streams

Infrastructure

Integrated Process

Demonstration (IPD)

Internal exposure

Inventory

Isotopic signature
A below-grade area in which elevated temperatures exist as a result of steam injection.

The sites, districts, structures, and objects considered limited and nonrenewable because of their association with historic events or persons, or social or historic movements.

Natural subsurface media (e.g., rocks and soil) having elevated temperatures as a result of steam injection.

Ground water pressure, measured as the height of a column of fresh water in equilibrium with the water.

Contiguous zones of ground water subject to investigation or remedial actions.

The effect, influence, or imprint of an activity on the environment. Impacts include direct or primary effects, which are caused by the project and occur at the same time and place, and indirect or secondary effects, which are caused by the project and are later in time or farther removed in distance but still reasonably foreseeable. Indirect or secondary effects may include growthinducing and other effects related to induced changes in the pattern of land use, population density, or growth rate, and related effects on air, water, and other natural systems, including ecosystems.

Natural or human-made subsurface obstructions such as solid rock, clay layers, or grout walls through which ground water cannot flow.

Unintentional release of a substance into the environment.

Waste streams entering a treatment, storage, or disposal unit.

Utilities and other physical support systems needed to operate a laboratory or test facility. Included are electric distribution systems, water supply systems, sewage disposal systems and roads.

An early phase of the Atomic Vapor Laser Isotope Separation project.

Radiation exposure from sources inside the body, such as. from materials ingested, inhaled, or (in the case of tritium) absorbed through the skin.

The amount of a radioactive or hazardous material present in a building or laboratory.

The radiological constituents that are characteristic of a particular material. 


\section{GLOSSARY}

(continued)

Land use

Legacy waste work-off

Low-level waste (LLW)

Magazine

Microbial filters

Mitigation

Mitigation measure
The purpose or activity for which a piece of land or its buildings is designed, arranged, or intended, or for which it is occupied or maintained.

The processing of waste that was generated before the implementation of a variety of regulatory and site-specific requirements which are currently applicable.

Waste that contains radioactivity and is not classified as highlevel waste, transuranic waste, or spent nuclear fuel or byproduct material.

An approved structure designed for the storage of explosives, excluding operating buildings.

A mass of microorganisms that serves to remove and destroy contaminants from water flowing through the mass.

As defined in CEQA, "'Mitigation' includes:

"(a) Avoiding the impact altogether by not taking a certain action or parts of an action.

"(b) Minimizing impacts by limiting the degree or magnitude of the action and its implementation.

"(c) Rectifying the impact by repairing, rehabilitating, or restoring the affected environment.

"(d) Reducing or eliminating the impact over time by preservation and maintenance operations during the life of the action.

"(e) Compensating for the impact by replacing or providing substitute resources or environments" (State. CEQA Guidelines 15370).

An action taken to reduce or eliminate environmental impacts. Mitigation includes avoiding the impact altogether by not taking a certain action or parts of an action; minimizing impacts by limiting the degree or magnitude of the action and its implementation; rectifying the impact by repairing, rehabilitating, or restoring the affected environment; reducing or eliminating the impact over time by preservation and maintenance during the life of the action; and compensating for the impact by replacing or providing substitute resources or environments. 


\section{GLOSSARY}

(continued)

Mixed waste

National Register of Historic Places

Natural uranium

Off-normal occurrence

Open space

Packaging

Passive bioremediation

Programmatic Environmental Impact Statement (PEIS)

Performance Evaluation and Verification (PEV) phase

Person-rem

Pilot Operations

Plume

Plutonium
Radioactive waste also containing RCRA-designated hazardous constituents.

A register of districts, sites, buildings, structures, and objects significant in American history, architecture, archaeology, engineering, and culture. It is under the jurisdiction of the U.S. Department of the Interior and was established pursuant to the National Historic Preservation Act of 1966, as amended (16 USC 470a).

Uranium as it occurs in nature. The natural substance is $99.28 \%$ uranium-238, $0.72 \%$ uranium-235, and $0.0055 \%$ uranium-234. Only the uranium-235 isotope is fissionable by slow neutrons.

An abnormal or unusual event or condition that adversely or potentially affects or indicates degradation in the safety, security, environmental or health protection, performance, or operation of a facility.

Any area of land or body of water set aside and left essentially unimproved that is dedicated, designated, or reserved for public or private use or enjoyment, or for the use and enjoyment of owners and occupants of land adjoining or neighboring such open space.

In the Nuclear Regulatory Commission regulations governing the transportation of radioactive materials (10 CFR 71), the term refers to a shipping container together with its radioactive contents.

The use of in situ biological treatment without human-made influences to accelerate treatment efficiency or throughput.

In the Council on Environmental Quality regulations for the preparation of National Environmental Policy Act documentation (40 CFR 1502.4 [b]), a PEIS is used to evaluate environmental impacts from broad federal actions such as implementation of a new program or regulation.

An intermediate phase of the Atomic Vapor Laser Isotope Separation project.

A unit of collective dose.

The final phase of the Atomic Vapor Laser Isotope Separation project.

The dispersion of a volume of contaminants in the environment. An artificial fissile metal of atomic number 94 . 
ppb

Prehistoric resources

Proposed project

Pump-and-treat method

Pyrolysis

Radioactive material

Radioactive waste

Radionuclide

RCRA Part B permit

Rem

Remedial action program

Removal actions

Riparian

Risk assessment

Ruderal vegetation
Parts per billion; equivalent to $\mu \mathrm{g} / \mathrm{kg}$ when referring to contaminant concentrations in solids; equivalent to $\mu \mathrm{g} / \mathrm{L}$ when referring to contaminant levels in water.

See Cultural resources (prehistoric).

For this addendum, the proposed project is the extension of the existing contract between DOE and UC for continued operation and management of LLNL.

The removal of contaminated ground water from the subsurface using extraction wells and the subsequent aboveground treatment of the ground water.

The heating of a compound under reduced oxygen conditions to break it down into its component parts.

Any material having a specific activity greater than 0.002 microcurie per gram, as defined by 49 CFR $173.4-3(y)$.

Material that contains radionuclides regulated under the Atomic Energy Act of 1954, as amended, and is of negligible economic value given the cost of recovery.

An unstable nuclide of an element that decays or disintegrates spontaneously, emitting radiation.

A permit to treat, store, or dispose of hazardous waste issued by the EPA under the Resource Conservation and Recovery Act or a delegated state agency such as the California Department of Toxic Substances Control.

The unit of dose equivalent that expresses the effective dose calculated for all radiation on a common scale. It is the absorbed dose in rads multiplied by certain modifying factors (e.g., the quality factor). The equivalent $S I$ unit is the sievert, abbreviated Sv; 1 Sv=100 rem.

A systematic set of activities designed to clean up one or more contaminated sites.

Cleanup activities that involve the physical extraction of contaminated media.

Located along the banks of streams, rivers, lakes, and other bodies of water.

Integration of the toxicity and exposure assessment into qualitative and quantitative expressions of risk.

A common plant growing where the native vegetation cover has been disturbed. 


\section{GLOSSARY}

(continued)

Run-on water

Significant effect

Siltation box

Site-wide remedial investigation report

Sludge

Soil vapor

Solid waste

Sound level

Steam injection
Noncontaminated surface water (typically stormwater) that flows onto a site.

As defined by CEQA, a substantial, or potentially substantial, adverse change in any of the physical conditions within the area affected by the project, including land, air, water, minerals, flora, fauna, ambient noise, and objects of historic or aesthetic significance. An economic or social change by itself shall not be considered a significant effect on the environment. A social or economic change related to a physical change may be considered in determining whether the physical change is significant.

A chamber in which some particulate matter settles out of a wastewater stream.

A report that summarizes environmental characterization activities performed at all suspect locations at a site.

Precipitated or settled solid matter produced by water and sewage treatment processes. In the context of this addendum, also the moist precipitate resulting from the dewatering of hazardous waste.

Gases that accumulate in the void space between soil particles above the ground water aquifer.

Any nonhazardous garbage, refuse, or sludge that is primarily solid; but may also include liquid, semisolid, or contained gaseous material resulting from residential, industrial, commercial, agricultural, or mining operations, and community activities.

The quantity in decibels measured by a sound level meter satisfying requirements of the American National Standard Specifications for Sound Level Meters S1.4-1971. Sound level is the frequency-weighted sound pressure level obtained with the standardized dynamic characteristic "fast" or "slow" and weighting $\mathrm{A}$ or $\mathrm{C}$.

The forced introduction of pressurized steam into the subsurface. 
Stockpile Stewardship and Management PEIS

Subsurface drains

Subunits

Surface impoundment

Taxa

Threatened species

Transuranic (TRU) waste

Trip generation

Tritium

TRU

TRU-mixed waste

Unusual occurrence

Uranium
The DOE maintains the safety and reliability of the nuclear weapons stockpile under the Stockpile Stewardship and Management Program. The PEIS evaluates different ways to implement the Stockpile Stewardship and Management Program and includes an evaluation of potential impacts of three proposed facilities: the National Ignition Facility, the Contained Firing Facility, and the Atlas Facility. It evaluates the potential impact of carrying out stockpile management alternatives at eight sites: Oak Ridge Reservation, Savannah River Site, Kansas City Plant, Pantex Plant, Lawrence Livermore National Laboratory, Sandia National Laboratories, and Nevada Test Site.

Human-made below-grade collection points to which water will flow because of reduced hydraulic resistance and from which water is pumped to the surface.

Individual components of a larger system that is subject to regulatory requirements.

An above-grade human-made pond used to contain wastewater.

The names applied to plant or animal groups in a formal system of nomenclature.

A species that is likely to become endangered within the foreseeable future throughout all or a significant portion of its range.

Waste containing $100 \mathrm{nCi} / \mathrm{g}$ or more of alpha-emitting isotopes of elements above uranium in the periodic table with half-lives of more than 20 years.

The number of vehicle trip ends associated with (produced by) a particular land use at a traffic study site.

A radioactive isotope of the element hydrogen, with two neutrons and one proton in its nucleus. Common symbols for the isotope are ${ }^{3} \mathrm{H}$, and $\mathrm{T}$.

See Transuranic waste.

Transuranic waste mixed with RCRA-regulated waste.

A non-emergency event or condition that exceeds the offnormal criteria, and relates to safety, security, environmental or health protection, performance, or operation of a facility. The occurrence requires immediate notification to DOE.

See Natural uranium. 


\section{GLOSSARY}

(continued)

Vadose zone

Vapor extraction

Vernal pool

Volatile organic compound

Waste Isolation Pilot Plant (WIPP)

Wetland

Workforce

Zoning
The zone of unsaturated material in soil or rock above the water table.

The withdrawal of soil vapor from the subsurface.

A wetland created from standing water, typically in the spring.

A compound containing carbon and hydrogen in combination with any other element that has a vapor pressure of $1.5 \mathrm{psi}$ absolute $(77.6 \mathrm{~mm}$ of mercury) or greater under storage conditions.

A facility in southeastern New Mexico being developed as a disposal site for TRU and TRU-mixed waste, not yet approved for operation.

Land or area with abundant moisture, saturated or inundated during some portion of the year; also used to describe plant species tolerant of such conditions.

Total labor force at LLNL, including UC and DOE employees and contractors.

The division of a city or county by legislative regulations into areas, or zones, that specify allowable uses for real property and size restrictions for buildings within these areas; a program that implements the policies of the general plan. 


\section{REFERENCES}

Aasen, Ke (1995), California Department of Fish and Game, Acting Regional Manager, Sacramento, CA, letter to Kenneth C. Zahn, Environmental Evaluations Group. (October 12)

Allen, Kathy (1996), Lawrence Livermore National Laboratory, Plant Operations Directorate, Plant Engineering Department, Utilities Division, Site 300 water, correspondence. (July 22)

Barker, Debra (1996), Lawrence Livermore National Laboratory, Plant Operations Directorate, Plant Engineering Department, Space and Site Planning Division, telephone conversation. (July 18, 23)

Carlsen, Tina (1996), Lawrence Livermore National Laboratory, Plant Operations Directorate, Environmental Protection Department, Group Leader, Environmental Chemistry and Biology, telephone conversation (September 16)

City of Livermore (1996a), Livermore Community General Plan, Planning Department, Livermore, CA. (July 19)

City of Livermore (1996b), South Livermore Valley Community Newsletter, Planning Department, Livermore, CA. (March 12)

City of Livermore (1996c), City of Livermore Zoning District Maps, Ordinance 1474, Livermore, CA. (May 13)

City of Tracy and The Planning Center (1993), City of Tracy General Plan, An Urban Management Plan, Tracy, CA. (July 19)

Conant, Bob (1996), City of Tracy Planning Department, personal communication. (July 16)

County of Alameda (1994), East County Area Plan, Alameda County General Plan, Volume 1, Alameda County Planning Department, Hayward, CA. (May 5)

County of Alameda (1992), Alameda County Zoning Regulations, Planning Department, Hayward, CA. (July)

County of San Joaquin (1996), San Joaquin County General Plan 2010 Map, San Joaquin County Community Development Department, Stockton, CA (March).

County of San Joaquin (1992), San Joaquin County General Plan 2010, Volume I:

Policies/Implementation, San Joaquin County Community Development Department, Stockton, CA. (July 29)

Cronister, Lisa (1996), U.S. Department of Energy, Oakland, CA. (August 9)

DOE (1996a), Draft Programmatic Environmental Impact Statement of Stockpile Stewardship and Management. Volume I. U.S. Department of Energy, Office of Reconfiguration, DP-25, Washington, DC. DOE/EIS-0236. (February)

DOE (1996b), Draft Programmatic Environmental Impact Statement for Stockpile Stewardship and Management. Volume III, Appendix I: National Ignition Facility Project-Specific Analysis. 


\section{REFERENCES \\ (continued)}

DOE/EIS-0236. U.S. Department of Energy, Office of Reconfiguration, DP-25, Washington, DC. (February)

DOE (1996c), Draft Programmatic Environmental Impact Statement for Stockpile Stewardship and Management. Volume III, Appendix J: Contained Firing Facility Project-Specific Analysis. DOE/EIS-0236. U.S. Department of Energy, Office of Reconfiguration, DP-25, Washington, DC. (February)

DOE (1996d), U.S. Department of Energy Environmental Assessment Under DOE NEPA Regulations, Decontamination and Waste Treatment Facility (DWTF), DOE/EA-1150. (June 6)

DOE (1996e), U.S. Department of Energy Finding of No Significant Impact for the Decontamination and Waste Treatment Facility at Lawrence Livermore National Laboratory. (June 12)

DOE (1995a). Federal Facility Compliance Act Proposed Site Treatment Plan for Lawrence Livermore National Laboratory. U.S. Department of Energy Oakland Operations Office, Oakland, CA. DOE/OAK Doc. No. 94-W 465/5400.2.a.3.1. (March)

DOE (1995b). U.S. Department of Energy Environmental Assessment for the Explosive Waste Treatment Facility at Site 300, at Lawrence Livermore National Laboratory. DOE/EA-1106. (November)

DOE (1992a), Final Environmental Impact Statement and Environmental Impact Report for Continued Operation of Lawrence Livermore National Laboratory and Sandia National Laboratories, U.S. Department of Energy and University of California. DOE/EIS-0157, $\mathrm{SCH} 90030847$. Volume I of $\mathrm{V}$, Text. (August)

DOE (1992b), Final Environmental Impact Statement and Environmental Impact Report for Continued Operation of Lawrence Livermore National Laboratory and Sandia National Laboratories, U.S. Department of Energy and University of California. DOE/EIS-0157, SCH90030847. Volume III of V, Appendix F, Table F-11. (August)

Farrell, Jill (1996), Lawrence Livermore National Laboratory, Plant Operations Directorate, Plant Engineering Department, Utilities Division, correspondence. (July 18)

Faubion, Jill (1996), Pacific Gas and Electric Company, Lawrence Livermore National Laboratory Account Manager, personal communication. (September 12)

Gallegos, Gretchen and Frank Gouveia (1996), Interoffice Memorandum to Judith Steenhoven, Lawrence Livermore National Laboratory. (August 1)

Harris, Steve (1996), Lawrence Livermore National Laboratory, Plant Operations Directorate, Environmental Protection Department, Operations and Regulatory Affairs Division, personal communication and telephone conversations. (July/August)

Hill, Donald (1996), Lawrence Livermore National Laboratory, Engineering Directorate, Beam and Fusion Division, correspondence. (July 26) 


\section{REFERENCES}

(continued)

Ives, Brent (1996), Engineering Directorate, Beam and Fusion Division, personal communication. (August 7)

Kato, Thom (1996), Lawrence Livermore National Laboratory, Plant Operations Directorate, Environmental Protection Department, Operations and Regulatory Affairs Division, personal communication. (August 30)

Knight, Dan (1996), Plant Operations Directorate, Environmental Protection Department, Operations and Regulatory Affairs Division, personal communication. (July)

Lane, James (1996), Lawrence Livermore National Laboratory, Engineering Directorate, Site 300 , site tour and electronic mail to Judith Steenhoven. (July, September)

Lawrence, Lucia (1996), Lawrence Livermore National Laboratory, Safeguards \& Security Department, Protective Force Division, telephone conversation. (July 19)

LLNL (1996a), ACI, A Cooperative DOE-EM and Industrial Project for Fast and Inexpensive Cleanup of Contaminant Plumes, Lawrence Livermore National Laboratory, Livermore, CA. UCRL-AR-124208. (July 9)

LLNL (1996b), Addendum to the Site-Wide Remedial Investigation Report, Lawrence Livermore National Laboratory, Site 300, Building 850/Pit 7 Complex Operable Unit. Lawrence Livermore National Laboratory, Livermore, CA. UCRL-AR-108131AD1. (February 1)

LLNL (1996c), ChemTrack Data Base System, Lawrence Livermore National Laboratory, Livermore, CA. (July)

LLNL (1996d), Draft Environmental Report for 1995, Lawrence Livermore National Laboratory, Livermore, CA. (June 28)

LLNL (1996e), Employee Residence Analysis, Lawrence Livermore National Laboratory, Livermore, CA. (May 29)

LLNL (1996f), Experimental Test Site, Site 300, Hazardous Materials Business Plan, Lawrence Livermore National Laboratory, Livermore, CA.

LLNL (1996g), Facility Information Tracking System (FITS), Facility Planning, Lawrence Livermore National Laboratory, Livermore, CA. (August 8)

LLNL (1996h), Lawrence Livermore National Laboratory, Livermore Site Part B Permit Application, Lawrence Livermore National Laboratory, Livermore, CA. (June 28)

LLNL (1996i), Lawrence Livermore National Laboratory Main Site, Hazardous Materials Business Plan, Livermore, CA.

LLNL (1996j), Recycling at Lawrence Livermore National Laboratory, Livermore, CA.

LLNL (1996k), Site 300 B-Division, Firing Areas Safety Analysis, UCRL-AR-122036, Rev. 0 (draft). 
REFERENCES

(continued)

LLNL (1995a), Draft Evaluation of Remedial Alternatives for the Building 815 Operable Unit, Lawrence Livermore National Laboratory, Livermore, CA. UCRL-AR-122369DR. (December)

LLNL (1995b), Environmental Report for 1994. Volume I, UCRL-50027-94. Distribution Category UC-702.

LLNL (1995c), Environmental Report for 1994. Volume II, UCRL-50027-94. Distribution Category UC-702.

LLNL (1995d), Remedial Design Report No. 5 for Treatment Facilities G-1 and G-2, Lawrence Livermore National Laboratory, Livermore Site. UCRL-AR-116583. (May 1)

LLNL (1994a), Environmental Report for 1993. UCRL-50027-93. Distribution Category UC-702.

LLNL (1994b), Final Site-Wide Remedial Investigation Report, Lawrence Livermore National Laboratory Site 300. Lawrence Livermore National Laboratory, Livermore, CA. UCRL-AR108131. (April)

LLNL (1993a). Environmental Report for 1992. UCRL-50027-92. Distribution Category UC702.

LLNL (1993b). Remedial Action Implementation Plan for the LLNL Livermore Site, Livermore, CA. U.S. Department of Energy, San Francisco Operations Office, Oakland, CA. UCRL-AR110532. (January 6)

LLNL (1992), Environmental Report for 1991. UCRL-50027-91. Distribution Category UC-702.

LLNL (1991). Part A Hazardous Waste Permit Application, Part A. EPA Form 8700-23 (01-90). Lawrence Livermore National Laboratory, Livermore, CA. (December 16)

LeStrange, Rexie (1996), San Joaquin County Public Works Department, Solid Waste Division, personal communication. (July 24)

Mahan, John (1996), Lawrence Livermore National Laboratory, Plant Operations Directorate, Plant Engineering Department, Maintenance and Operations Division, telephone conversation. (August 1)

Mancieri, Saverio (1996), Lawrence Livermore National Laboratory, Plant Operations Directorate, Environmental Protection Department, Operations and Regulatory Affairs Division, summary of LLNL environmental incidents, January- June 1996. (July 23)

Matthews, Sandy (1996), Lawrence Livermore National Laboratory, Plant Operations Directorate, Environmental Protection Department, Operations and Regulatory Affairs Division, personal communication. (August 26)

McElligott, Liz (1996), County of Alameda Planning Department, personal communications. (July 15, 16) 


\section{REFERENCES}

(continued)

McNeely, Kim (1996), Livermore Valley Joint Unified School District, Facilities Planner, personal communication and facsimile transmittal. (July 24)

Medlin, Joel (1995), U.S. Fish and Wildlife Service, Field Supervisor, letter to Kenneth Zahn, Environmental Evaluations Group. (September 22)

Metal, Dianne (1996), City of Livermore Sewage Treatment Plant, personal communication. (July 24)

Miller, Diane (1995), Lawrence Livermore National Laboratory, Plant Operations Directorate, Plant Engineering Division, Transportation Systems Manager, personal communication.

(September 9)

National Oceanic and Atmospheric Administration (1995), Climatological Data Annual Summary, volume 99, numbers 1 and 13, ISSN 0145-0069.

Neuman, Rose (1996), Lawrence Livermore National Laboratory, Laboratory Communications and Public Information, Livermore site tour. (July 2)

Orloff, Sue (1986), Wildlife Studies of Site 300 Emphasizing Rare and Endangered Species, Lawrence Livermore National Laboratory, San Joaquin County, California, prepared for Lawrence Livermore National Laboratory by BioSystems Analysis, Inc., Sausalito, CA.

Parisotto, Rudy (1996), Lawrence Livermore National Laboratory, Plant Operations Directorate, Plant Engineering Department, Maintenance and Operations Division, facsimile transmittal. (August 1)

Paukert, Larry (1996), Lawrence Livermore National Laboratory, Plant Operations Directorate, Plant Engineering Department, Administration Division, Site 300, correspondence. (July 22)

Rued, Warren (1996), Lawrence Livermore National Laboratory, Plant Operations Directorate, Environmental Protection Department, Operations and Regulatory Affairs Division, personal communication. (August 27)

Ruiz, Salvador (1996), Lawrence Livermore National Laboratory, Operations Directorate, Business Services Department, Services Support Division, correspondence. (July 31)

Shingleton, Kathleen, (1996), Lawrence Livermore National Laboratory, Plant Operations Directorate, Hazards Control Department, personal communication: Contract 48 between the University of California and the U.S. Department of Energy, Appendix F, Performance Measure 1.1.A, Radiation Protection of Workers. (July 12)

Tiernan, Peggy (1996), San Joaquin County Community Development Department, personal communication. (July 18)

United States Enrichment Corporation (1996), Environmental Assessment for the AVLIS Integrated Process Demonstration. USEC/EA-96001. (January) 


\section{REFERENCES}

(continued)

White, David (1996), Lawrence Livermore National Laboratory, Defense and Nuclear Technologies Directorate, B Division, Site 300 tour. (July 12)

Woollett, James (1996), Lawrence Livermore National Laboratory, Environmental Protection Department, Operations and Regulatory Affairs Division, personal communication. (July 16, July 24, and August 14)

Zeiner, D.C., W.F. Laudenslayer, Jr., and K.E. Meyer (1990), California's Wildlife, Volume II: Birds, California Statewide Habit Relationship System, California Department of Fish and Game, Sacramento, CA. (November) 


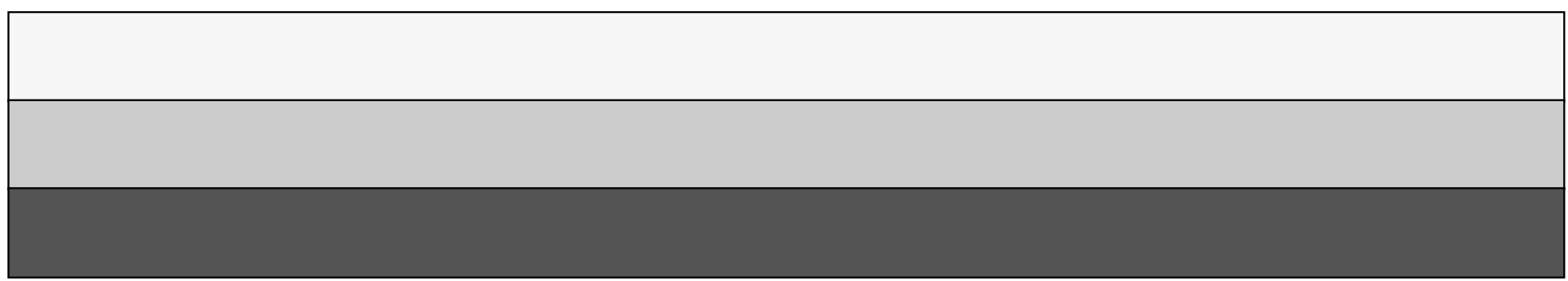

